\title{
レ線映画による上部尿路排尿運動の研究
}

\author{
名古屋大学医学部泌尿器科教室 助手 須 山 敬 二
(主任: 清水圭三教授)

\section{CINERADIOGRAPHIC STUDY OF UPPER URINARY TRACTS} \\ Keiji Suyama \\ From the Department of Urology, Medical Faculty, Nagoya University.
}

(Director: Prof. Keizo Shimizu)

The physiological movements of the miction of the upper urinary tracts were studied by $16 \mathrm{~mm}$ X-ray cinematographic method using Philips image intensifier, Shimazu X-ray tube with rotating anode and Shimazu X-ray apparatus $1000 \mathrm{~mA}$ type. Cinepyelograms were taken by Bolex H 16 cinecamera installing Switer F. 1.4 lens with Sakura $16 \mathrm{~mm}$ ASA 200 negative film or Fuji $16 \mathrm{~mm}$ cinefluorographic film. The usual exposure factors were from 1 to $4 \mathrm{~mA}$ and $60 \mathrm{KV}$ and the film speed was 8 frams per second. The analyse of cinepyelograms were performed by ordinary vision and slowly motioned projection. Moreover, the action of different portions of the upper urinary tracts were investigated at still position based upon the serial measurement of the diameter of the calyces, pelvis and ureteropelvic junction on the fullsized image of the retrograde cine-pyelograms using a single framing projector.

1) Cineradiographical studies were performed in normal persons including 4 cases of female and 1 case of male, and the following results were obtained.

The peristaltic contraction passes uninterruptedly from the fornix to the upper portion of ureter through calyceal neck and pelvis. This movement occures periodically and transmitts to the urinary bladder. At the resting phase the rapid but incomplete peristalsis are observed in the calyces. It seems to send the excreted content of calyces to the dilated pelvis.

The contraction waves of the periodical peristalsis begin simultaneously from all fornix in 2 cases out of 4 at the supine position and in 1 case out of 2 at the erect position. In all cases, the upper and middle calyces begin the systolic movements simultaneously at the portion of fornix. But in 2 cases of them, the lower calyces show the retardation of the contraction because of the regurgitation of the contrast medium. From the comparison of systolic pattern at the ureteropelvic junction and pelviocalyceal junction, it is presumed that there is no sphincteric coordination to prevent the regurgitation into them.

At the transmission of contraction wave from the calyces to the pelvis, the regurgitation has been observed at each calyces in 2 cases of them. It is considered that the calyceal regurgitation may damage the renal papillae due to the rise of intrapelvic pressure.

There are no essential variation in the contraction waves at the supine and erect position. But at the erect position a tendency of elongation of the systolic phase is seen at all portions.

There is no relationship between the beginning of systole and respiratory movement. The duration of the contraction is 8.5 to 19.4 seconds in supine position and 6.2 to 12.8 seconds in erect position. The contraction wave at erect position is shortended and frequent.

The time of the disappearance of radio-opaque medium from the calyces and pelvis is $4 \mathrm{~min}$. 9 sec. to $8 \mathrm{~min}$. $46 \mathrm{sec}$. at the supine position and $1 \mathrm{~min}$. $20 \mathrm{sec}$. to $4 \mathrm{~min}$. $48 \mathrm{sec}$. at erect position. Namely excretory time at the erect position is shortened as near half of supine position.

2) The urinary movements of the upper urinary tracts in 14 cases (21 affected kidneys) of movable kidney were observed cineradiographically, and the following results were obtained.

As well as the occasion of the normal kidney, the periodical peristaltic contraction begins from the fornix to the upper portion of ureter through the pelvis, but at the erect position the diminution or disappearance of contraction is seen at times by the accumulation of the contrast medium due to the descent of the kidney. 
In a case of movable kidney associated with hydronephrosis the contraction of fornix is not found both at the supine and erect position. The periodical peristaltic contraction of pelvis disappears in 5 cases out of 21 affected kidneys at erect position. It may be caused by the accumulation of the contrast medium in the pelvis secondary to the bending of pelvioureteral junction. At the upper portion of the ureter, all of the cases show the periodical peristaltic contractions and in over a half cases show normal movements.

The time of disappearance of contrast medium in the fornix and pelvis is delayed in the most cases of movable kidney. It takes over 10 min. in 3 affected kidneys (14.3\%) at supine position and over $5 \mathrm{~min}$. in $17(80.9 \%)$ at erect position. The cases that the excretion time at erect position is delayed much more than that at supine position are 11 cases $(52.38 \%)$. It means that the contrast medium is so easy to accumulate into the pelvis at erect position. Delay of excretion time nearly corresponds to the grade of the descent of kidney.

After the nephropexy of the movable kidney, the peristaltic contractions become normal and the accumulation of the contrast medium in the pelvis disappears. The excretion time of the contrast medium in the fornix and pelvis at erect position is shortened from $6 \mathrm{~min}$. $37 \mathrm{sec}$. over $15 \mathrm{~min}$. preoperatively to $38 \mathrm{sec} .6 \mathrm{~min} .45 \mathrm{sec}$. postoperatively.

\section{第 I 編 正常腎上部尿路排尿運動}

\section{I 緒 言}

上部尿路の観察はレ線尿路造影法の発展から急速な進 歩定遂げたが，尿運搬機構の研究特に生体内での腎杯， 督孟の排尿生理は主として解剖学的理由による運動観察 の困難から未だ解明されない点が甚だ多い．管腔臟器の レ線学的動態撮影法としてレ線映画撮影法は, 運動像の 連続性乞再現の忠実性に扮いて最むすぐれている. 然し ながら従来用いられたレ線間接映画撮影法は，低輝度の 蛍光板像を撮影するために大量のレ線放射を必要とし, 被検者, 術者共にレ線障害が歪慮された. 高輝度蛍光板像 と放射レ線量低減への努力は, 近年エレクトロニクスの 進歩からレ線像增倍管 (fluoroscopic image intensifi$\mathrm{er}^{82)}$, X-ray image amplifier ${ }^{48)}$, Bildwandler ${ }^{25)}$ の出現 となり多くの障害は解決されるに至つた。 本邦では当教 室に扮いて昭和30年 Philips image intensifier を用 いて, 初めて16ミリレ線映画の撮影に成功して以来膀胱 及び精震腺, 精管運動像の分析を行つた三矢他 ${ }^{92)}$, 三矢 他 ${ }^{93)}$ 及び浅井 ${ }^{8)}$ の詳細な報告がある、私はこれ迄に正常 腎 9 例，遊走腎 14 例，腎結核 2 例，腎腫瘍 2 例，腎結石 1 例の逆行性腎孟レ線映画像について上部尿路排尿運動 を報告したが，今回腎杯，腎孟，上部尿管像の計測法を 併用し, 計測に適した 4 例の正常腎について運動時相の 比輷を試み, 上部尿路排尿機序の考察を行つた。

本論文の要旨は, 第 7 回日.本泌尿器科学会中部連合地 方会及び第 $45 ， 46 ， 47$ 回日本泌尿器科学会総会で発表 し，映画を供臨した。

\section{II 交献的考察}

上部尿路運動に関する研究では電気生理学的に尿管運
動を観察したものが多く，レ線学的に腎孟，腎杯の運動 を具体的に示しをものは極めて少い。

尿運搬に関与する上部尿路平滑筋の観察柱, Henle （1866）が腎乳頭基部を取巻く輪状括約筋一一乳頭基部括 約筇 M. sphincter papillae 発見して, この収縮が乳 頭を圧迫して集合管より尿排出に寄与するとし， Disse は1902年腎杯腎孟移行部にある強力な 輪状筇束を 記載 し，腎杯を閉鎖する能力があるとした，後に Haebler ${ }^{43)}$ は Henle の括約筋孛 Sphincter papillae superior, Disse の括約筋を Sphincter papillae inferior と命 名した。 との 2 筋の報告から Westenhöfer ${ }^{137)}$, Haebl$\mathrm{er}^{43)}$ の Melktheorie へ発展した. Haebler は Sphincter papillae sup. Austreibsmuskel, Sphincter papillae inf. Adwehrmuskel と考え，腎杯には自 律的に週期的収縮運動が起るものとした. Haebler の Sphincter papillae inf. が腎孟内容の腎杯への逆流を 防ぐ機能があるとしたのに対し, Westenhöfer は Saugpumpe の作用があるとして腎杯運動を尿分泌に対する 機能として観察している. また Muschat (1926) ${ }^{96997)}$ ${ }^{98)}$ 恃腎杯壁の連続切片办ら腎杯々は上記の 2 輪状筋の間 を螺旋状に走る橋状筇組織があると述べ， M. spiralis papillae なる一新筋を提唱し,Spiral muscle の収縮は 乳頭に対し milking actionを及注し, 全腎杯内容が排 出される事を動物で実験した. Fuchs $(1936){ }^{40)}$ 法乳頭 基部輪状筋が組織学的に弱小乃至欠除する事から, 乳頭 よりの尿圧排機能を否定して円蓋部再吸収説を提唱し た.

Narath (1940) ${ }^{99}$ は腎杯平滑筇の解剖学的研究とレ 線連続撮影法により得られた所見から，第 1 図の如き腎 
杯運動と腎孟尿管移行部協調による排尿運動説を発表し て注目されるに至つた。即ち腎杯に注円蓋部括約筋 M. sphincter fornicis と腎掹開口部にある婜杯括約筋 M. sphincter calycis の 2 輸状筇を举将, 縦走筋は涪济乳

第 1 図

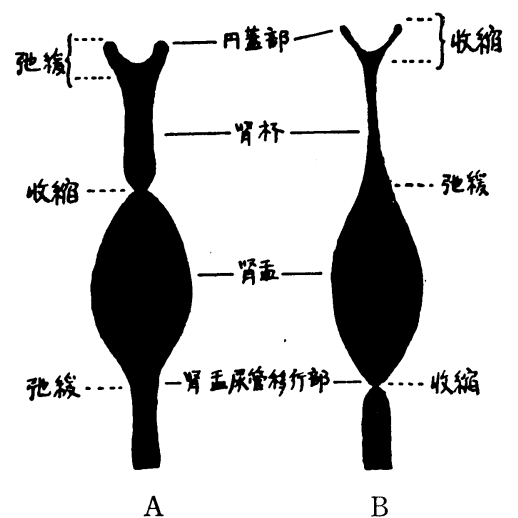

Narath の堅杯, 腎孟尿排出機構

J. Urol., 43, 151ょり

第 2 困

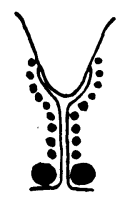

(1)

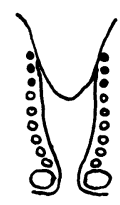

(n)

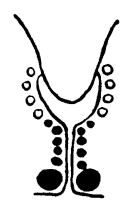

(2)

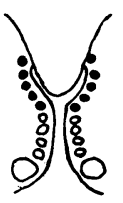

(6)

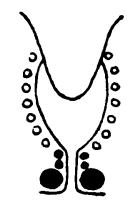

(3)

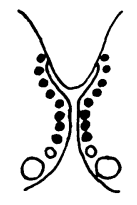

(7)

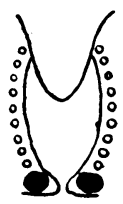

(4)

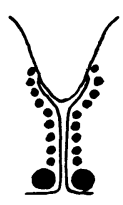

(8)
辻氏の腎杯輪状筋運動説

辻氏「督の平滑筋」73頁ょり

頭先端の高さで 2 分される上, 下腎杯縦走筋に分け，そ の外に一新筋として円蓋部挙筋 M. levator fornicis $の$ 存在を提唱した。彼は腎杯運動を. collecting phase と emptying phase に分け, collecting phase では円蓋 部挙筇は弛緩して円蓋部は下降し, 円蓋部括約筋の弛緩 と同時に腎杯縦走筇の上部は収縮して円蓋部括約筇の弛 緩を助け, goblet が強制的に作られて腎杯内に陰圧が生 じ，尿は集合管から吸出される．乙の時の陰圧形成を腎 の滤過圧上同様に尿運搬の因子として重要視している. collecting phase の間, 督杯腎盂移行部の腎杯括約䇨 は収縮していて腎孟の収縮を開始する時に尿の腎杯内逆 流を阻此している(第1図A).

goblet に充分尿が満されると emptying phase に かわり, 腎杯運動は逆になる. 即ち腎杯縦走筋の上部は 弛緩して円蓋部括約筫注收縮し乳頭下で Cap 形成が起 る. この封円蓋部挙笳は収縮して円蓋は挙上され, Cap 形成以乳頭に密着して腎杯内容が集合管へ逆流するのを 阻止すると述べている. との Cap 形成は後のレ線学的 研究によれば不完全で殆んど造影剂が残留すると訂正し た. Cap形成已同時或法直後に腎杯括約筋注腎杯縦走筋 の収縮に助けられて弛緩し尿を雨杯上り腎孟へ排出する （第 1 図B）乙の腎杯運動快更に腎孟の運動々腎孟尿管 移行部の括約筋的機能とよく協調して抢り, collecting

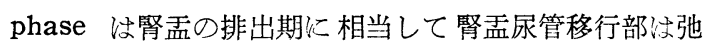
緩し，腎盘内容を尿管へ排出する一方腎杯腎㙉移行部は 閉鎖して逆流を防ぐ. emptying phase には腎孟の桩 張期にあつて腎孟尿管移行部注收縮して尿管上りの逆流 を防止し，腎㙉内に僅かな陰圧がつくられて腎杯へ作用 すると述べ，六くして腎杯ょり尿管へ排出されると云う Narath の括約筇的協調運動説は上部尿路に打排 尿運動を具体的に示した最初の学説である.

辻 $(1953)^{134)}$ は40腎についてその平滑筋の構造排列の 詳細を記載した。 その所見は腎孟, 腎杯では概衫内縦, 中輪, 外縦の 3 層に区分され, 互に移行して網状構造を 呈し, 腎被膜下平滑笳層は腎門部において反転して腎洞 内面を被い, 多くは錐体に沿つて縦走下行して円蓋部を 越えて腎杯縦走筋に移行する。腎杯輪状筋は腎杯の腎孟 開口部に位置する強力な括約筋は腎杯の腎盂開口部に位 置する強力な括約筋 (腎杯括約筋) 功円蓋部まで腎杯 壁全長に亘り, 相並んで存在し, 更に円蓋部以上 ( Henle の乳頭基部括約筋) 錐体の隣接錐体或はベルタン氏 腎柱への移行部迄続いて抢り, Muschat の spiral muscle 注誤りであるとと, Narath の円蓋部括約筋沙 杯全身に亘つて存在する輸状筋の一部で，一独立性括約 筋ではないと否定した。また自己の所見から乳頭より腎 孟に至る尿邁搬機構は，錐体基部より腎孟腎杯移行部迄 の全長に亘り存在する輪状筋の上部より順に下方へ上続 いて行く一連の収縮弛緩運動によると推測し, 第 2 図の 蠕動形式の尿排出説をとつている.

Hanley (1953) ${ }^{47)}$ が electro-ureterogram を発表 してから生体内での尿管運動が尿管電図として観察さ れ, その運動哕くの報告者により蠕動形式の収縮々看 
做されている.乙れによる人生体における尿管蠕動の週 期を見ると, Milton 等 ${ }^{86}$ 怯毎分 $4 \sim 6$ 回, Bors等 ${ }^{20)}$ は 20 秒以下に 1 回, Butcher 等 ${ }^{23}$ は毎分 0.8 10回, Corey 等 ${ }^{27)}$ は每分2.47回の割合で収縮が起るとしている.

横竹 $(1957)^{134)}$ は尿管電図から, 尿管蠕動運動が腎端 より膀胱端に至るまでに $2 \sim 8$ 秒を要し, 週期は 12〜23 秒であると述べ, Butcher と同様時行逆蠕動を観祭し ている. 生亀 (1957) ${ }^{59}$ は平均14.5 土5.77秒の週期を有 する尿管螦動運動を報告している．また腎孟の電図を記 録し, 腎盂と尿管の棘波は形, 電位が異なり, 腎盖の数 コの棘波の波高值が次第に増加して最大となつた最後の 波が尿管に伝播する尿管電眓を記載し，伝播するための 刺㦸閾值が尿管の方が腎盎より高く, 数回の腎盂の興奮 の加重によつて尿管の興奮の闇値を越えて伝播するので はないかと述べ，尿管のペースメーカーは腎孟炕る が，その興舊による棘波の伝播は心臟にみられる程確実 ではなく，いくつか目が伝えられるのではないかと考え ている，そして尿管の棘波と尿管蠕動とはよく一致する ことを確め, 体位による腎盂排出量を観察して頭例を低 くすると腎孟内に尿が詝溜され易いととを示す実験を報 告している.

上部尿路内圧上排尿運動 との関係を見ると，Lacus (1908） ${ }^{77)}$ 小大の実験で腎㙉内圧が零であつても蠕動が 見られ，尿を腎盐より排出する事は興味ある事で腎跙内 圧が上昇すると直ちに蠕動の活動性が高香ると述べてい る.

Lapides (1948) ${ }^{78)}$ は無傷の人尿管の緊張度と週期的 收縮は，中枢神経系及び 尿管のガングリアとは関係な く, 分泌された尿による尿管平滑筇線維の伸展が刺战と なつて尿管蠕動が開始され持続されるのであつて, 尿管 虂動運動は分泌される尿量によつて変化すると述べてい る. その他佐谷 ${ }^{131}$, Trattner ${ }^{131)}$, Morales 等 ${ }^{94)}$ の報告 がある。

Davis $(1954)^{30}$ は体位等の变化による腎孟内压を測 定し, 仰卧位 $8 \sim 15 \mathrm{~cm}\left(\mathrm{H}_{2} \mathrm{O}\right)$, 坐位 $12 \sim 15 \mathrm{~cm}\left(\mathrm{H}_{2} \mathrm{O}\right)$, 立 位又は歩行時17 18cm $\left(\mathrm{H}_{2} \mathrm{O}\right)$, 重い物を持与上げた時 23 $\mathrm{cm}\left(\mathrm{H}_{2} \mathrm{O}\right)$ で呼吸による压の変動は, $1.0 \mathrm{~cm}\left(\mathrm{H}_{2} \mathrm{O}\right) て$ あると報告し, 腎盂内圧は腹内圧の影響が大きい事を述 べている.

Kiil (1957) ${ }^{72)}$ は 214例の urometoric recording 行い, 腎杯ょり膀胱に至る種々の高さで収縮波圧を記 録した結果，尿管内では時間と共に膀胱側へ移動する10 〜 $80 \mathrm{~mm} H \mathrm{Hg}$ 収縮圧波動を記録したのに反して腎孟内では
殆えどの例に收縮期已休止期を区別出来了压波動は認め

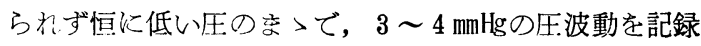
した少数例は腎㙉を伸展させた例外的な症例としてい る。腎杯内では陽圧乃至は陰圧恬いづれも記録されず， 生理的食塩水を急速に腎杯内に注入すると，腎盂へ注入 しな時上同様初ぬて律動的収縮波が記録されたと述べ, 腎孟の収縮が記録された症例では腎盂と尿管の収縮数は 同数で腎盂の収縮は尿管の収縮に先行 したと述べてい る. 呼吸運動と圧変動の関係は $2 \mathrm{~mm} \mathrm{Hg}$ 以下の規則的な圧 波動が蝚動休止期に見られ，吸気の間に最高まで上昇し たが収縮律動と頻度は呼吸圧変動とは無関係であつたと している．末た腎孟内圧が少しも上界しないで毎分 $8 \mathrm{cc}$ の尿が腎㙉から排出された警くべき報告をしている. 彼 は更に内压の記録とレ線撮影を同調させて, 压波動と収 縮波が全く一致する事を確認した外各腎杯頚部の収縮 は，腎盂の収縮と注無関係に起きるとなし，腎盂腎杯逆

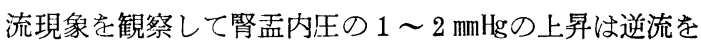
起さ地るのに充分であり，腎杯への逆流が存在する事は 腎杯括約筋は腎孟内压の極く軽度の上界にも耐えられな い事を示すもので上記の所見から，腎杯と腎孟との間の 巧妙な機能的協調作用は腎機能を保護するために必要な ものではなく，腎杯の括約筋運動は明らかに尿運搬にと つて重要なものであると結論している.

レ線学的研究の概要を見ると, ポリソグラフィーによ る観察は Narath ${ }^{99}$ とよつて腎杯括約筇の運動像が示さ れているが, 易動藏器では撮影時期は偶然性しか期待出 来ないようである。

ピエロスコピーは上部尿路に执いては特に低輝度の蛍 光板像のため不鮮明で, 運動の所見は術者の主観により 左右され易く，記録方法がないととは最大の久点となっ ている.

Gona \& Flecker (1930) ${ }^{65)}$ は逆行性腎盂像で, 腎杯 には $1 \sim 3$ 秒間隔で上腎杯に始まり中, 下腎杯に移行す る収縮を認め, 腎杯運動の後に腎孟は snap-like action で収縮し，尿管の蠕動と腎㙉腎杯逆流を観察している。 Junker (1936） ${ }^{66)}$ は瞬間撮影を併用し, Alken \& Büshner $(1953)^{5)}$ はレ線連続像を併用して上部尿路の運 動学蠕動運動として観察している. 本邦に执いても尾形 $(1928)^{104)}$, 根岸, 小島 $(1931)^{102)}$ の報告がある. Manges $(1918)^{85}$ により始められた本法も従来の方法では 今日殆んざ顧られていないが， レ線像增倍管の出現によ り今後再び泌尿器科臨床に抢ける重要な検査法の一つを なるものと考えられる.

レ線 キモグラフィーによる上部尿路の運動像は, 
Maint $z$ 等 $(1938)^{83384)}$ によれば，腎杯乞腎孟の収縮時相 は腎孟収縮中上腎杯は拡張している場合も収縮している 場合もあり，両者共に収縮しているとともあつて種々の 配合をとり,両者の運動に似何ら連絡もないとしている. 木下 $(1938)^{\left.{ }^{76}\right)}$ は尿管運動虫督孟運動の連続として発 生し, $5 \sim 10$ 秒の週期で膀胱に向う蝡動運動と, 之に直 角の方向の振子運動主主要なる運動とし, 螨動波の長さ は $5 \sim 13 \mathrm{~cm} て ゙$ 每秒 $2 \mathrm{~cm}$ 内外の伝動速度を有すると報告し た。高橋等 $(1941)^{130)}$ 沬腎盂の収縮運動は中絶される ととなく連続的に尿管に伝播されるものにして，尿管頚 部に执いても尿管の他の部分々同様の収縮蠕動運動があ り，特江括約筋椂収縮を営む部分法認められないと述べ ている，小野 $(1941)^{105)}$ は，腎杯では上督杯にのみ明 瞭な収縮を認め，腎杯先端部上り腎盂に向う収縮䌮動が あり，腎盂に抄いても尿管と同様収縮蝶動的に上方か ら下方へと進行し，上腎杯之腎孟の収縮数梽同数で腎杯 と腎孟の收縮時相から督孟の収縮蠕動は上腎杯の収縮に 連続する々推論し，腎孟より尿管へ直接且連続的に移行 する収縮蠕動を認めている。

レ線キモグラフィーは一種の運動描記法として多くの 新知見を残したが，同時に多方向の運動を観察すること が出来ず，特に腎杯の運動についてば満足すべき結果が 得られていない。

レ線連続撮影法による研究を見ると，山口（1933） ${ }^{1411}$ は，腎杯はすべて同時に収縮運動を営宗ず交互に輸状筋 は強く收縮して腎杯沿を全く閉鎖し，腔内の尿导排出す ると同時にその逆流を防ぎ，腎盂は定間隔正調複雑なる 波状蠕動運動学行い, 更に尿管移行部も一定時学保与強 力なる收縮化より一時腎盂内に尿安貯溜过しめ, 且排出 された尿の逆流を妨げると述い゙ている。

Narath $(1940)^{100)}$ 柱自己の考案した連続撮影装置で, 1.15〜 2 秒間に 4 枚の連続像を撮影し, 得られた所見か らの腎杯運動と腎杯括約筋と腎孟尿管移行部の協調的排 尿運動説は既に述べた通りである。

Johnson (1952) ${ }^{64)}$ は， $0.5 \sim 2$ 秒間隔で 8 枚の連続 撮影が出来る Sanchez-Perez automatic seriograph により研究を行つた，それによると，小大腎杯，腎孟， 尿管,膀胱の移行部で分節的収縮が営まれるが, 同一人で の両腎の収縮像を見ると，1例の腎は小大腎杯已腎盖は 分節間の括約筋による分節的収縮を営み，他側腎では括 約筋的收縮は腎孟尿管移行部のみで，腎杯之腎孟は同時 性収縮を示すと云うょうに，左右で全く異つた像と週期 及び運動の強さが示され，他の症例との比較でもその排
出運動像が全く異つて抢り，尿管の蠕動が下万に始まる 前に幾つかの腎杯，腎䀃の収縮が起るのが認められたの で, 生理的に impulse 注腎杯亦ら膀胱へ円滑に通過し ないものとした。彼法若し上部尿路が神経的支配によつ て調整されているならば，腎杯運動と腎孟及び腎孟尿管 移行部の運動乞の関係沬いづれの腎でも多くの不変性を 示すであろうと考えたが, 彼の得たレ線像は驚く程異つ ていたので，之の所見の解釈に尿路分節に抢ける闇値対 液圧の前提を考え，1）上部尿路運動への唯一の刺战は 尿路自体内の液王（尿）である，2）収縮汸液王が尿路 の特定の分節の䦨值に達した時に現われる．3）一般的 に収縮の閾値は上部の分節程低く，䦭值は筋壁に対する 腔の経比と大体相関する．即ち腎孟と尿管が同じ压を受 けると先に腎孟が収縮するのは，腎孟が比較的大きな内 脆と薄い筋肉を持つているので闌值が低いからであると 説明し, この 3 つの前提をレ線連続像と一致させるため に彼注, 上部尿路にパスカルの原理が適用されるとして 腎杯，腎孟尿管移行部及び 尿管膀胱移行部で 作用する 括約筋によつて個々の収縮閾值を有する小さなパスカル 単位に分け，括約筋はそれぞれその閾値は異なるけれど も上方卜りの王力は括約筋を開口せしめ，下方上りの压 はそれを閉鎖させると云う法則に従つて尿の逆流水阻止 され，腎杯から膀脱へ分節的に下方へ進行する收縮が営 まれると仮定した．そして上部尿路の連続した蠕動運動 による尿排出には不定的であり，外的神経調節沈ないと して Lapides の結論孛支持し, 機能的括約筋は存在す るが部位，個人により異なると云い，震動波は腎杯より 膀胱をで必ずしも達しないと述べているが，一分節に拉 いて液王を高內る収縮は，蠕動波とみなしている。

レ線連続撮影法注，ほ医実物大の陰影が得られるが, 撮影枚数が限定されるの梳点である.また同法による 上部尿路の運動が，いずれも分節的収縮運動と看做され。 ていることは興味が梁い。

レ線胦画々，Raynolds (1928) ${ }^{1100}$ によて始められ た間接レ線映画撮影法が広く用いられ，主として心脈 管, 消化器, 関節運動の観察が行われ, Raynolds (1935) ${ }^{111)}$, Stewart $(1937)^{125)}$, Decastro $(1947)^{311}$, 河石 $(1936)^{70)}(1938)^{71}$ 等の報告がある.

当教室三矢辰雄名誉教授 ${ }^{88)}{ }^{92}$ は, 泌尿器科領域に括 ける運動の観察にはレ線映画撮影法の必須なる事を囯に 看破し, 昭和10年初めて家鬼及び犬の排尿運動を撮影し て第 4 回関東，東北連合地方会に捛いて供覧した。昭和 12 年田村 ${ }^{89)}$ と共に人体上部尿路運動を報告してより，大 
原 ${ }^{107)}$ の正常上部尿路, 大田 ${ }^{106)}$ の尿管結石症例, 兼松 ${ }^{677}$ ${ }^{68)}$ の結核腎の上部尿路排尿運動の研究があり, 下部尿路 排尿運動の研究には村上 ${ }^{951}$ ，水野 ${ }^{87}$ )等がある。. また射精 運動には成田 ${ }^{101)}$ の観察がある。当時のレ線叫画撮影法 は，低輝度の蛍光板像を低感度の 35 ミリィルムに収め る方法で，尿路に招ける撮影には特に大量レ線放射を要 し， レ線障害の危険を含むため長時間の観察柱不可能で あつた。

近時レ線像增倍管の出現となり従来の欠点流大いに改 良された。1955年吾々はフィリップス製レ線像增倍管を 用い, 16 ミリレ線咉画撮影に成功したので著者もその一 人として三矢他 $(1957)^{92)}$ と共にレ線像增倍管の詳細々膀 胱排尿運動を報告した. 浅井 $(1957)^{8)}$, 三矢他 (1960)

${ }^{93)}$ は同法による射精運動を報告している.

レ線像增倍管を使用したレ線胦画による上部尿路運動 つ観察は, Hanley $(1955)^{48)}$, Catel 等 $(1957)^{25)}$ Bo dner 等 $(1958)^{15)}$ の報告がある.

レ線映画による上部尿路運動の概要は，大原 ${ }^{107)}$ によ れば，腎杯上り腎㙉を経て尿管に連続移行する週期的蠕 動収縮弛緩運動が行われ，腎杯は腎杯乳頭側より腎盂に 向つて進行するが時には腎杯䅡部より開始されるを見， 各腎杯愔時を異にして運動を行い，一斎に開始し一斉に 終了するものではない，末た各腎杯間において一定の運 動の序列を認めないが, 各腎杯の運動時相涊総括的に腎 孟の運動に先行すると述べ，腎杯と腎孟の收縮回数汸， 添济同数であつて腎盐の 1 回の収縮に対し，3〜4回の 腎杯収縮を見を症例は例外的なものとしている。年た腎 孟の運動時間は, 仰臥位 $3^{7} / 12 \sim 7^{6} / 12$ 秒, 立位 ${ }^{13} / 16 \sim 4$ $3 / 12$ 秒で仰臥位が長く, 運動週期㤝, 仰卧位 $7^{1} \%_{12} \sim 11$ $9 / 12$ 秒, 立位 $2^{5} / 8 \sim 6^{6} / 8$ 秒で立位をとると, ょり頻回に 蠕動収縮が行われると述べている。.太田 ${ }^{106)}$ は永管結石 症例では疝痛発作時には結石介在部より上部では結石を 下降せしめるょうな強い蠕動運動が見られ, 腎盖治強直 痤卛を起し, 介在部より下部の尿管では強烈な逆蠕動を 認め, 間歇期にあつても局所的不規則な収縮弛緩運動が 認められると云つている。

兼松 ${ }^{(6)}$ は, 正常㛑杯も相互間に何らの関連むなく個々 に単独的運動を行い, 頝部に括れ状の収縮が見られ, 腎 杯運動は腎孟, 尿管運動より頻回に行われて, 腎孟 1 回 の収縮に対し腎杯は 9 回の収縮を久た症例があると述 べ，腎盂の運動之一貫したものがなく偶々腎盂の収縮す る直前に起つ蠕動波が連続していると考えるべきもの であるとしている.しかし腎孟の運動は，8粉撮影で 5 $\sim 73 / 8$ 秒の週期で規則的に発現し, 上部尿管に連続移行 する蠕動運動を認め，尿管は 1 コの収縮輪が下行するも のではなく，収縮仙持続されたま〉で蠕動的に下方に進 行して一時法尿管の殆んど全長に亘り収縮し陰影の全消 失として観察され，弛緩も上部より開始し全尿管が露呈 すると述べて㧍り，Narath $(1954)^{100)} の レ$ 線連続撮影 による尿管の漂浪 3 つの分節的運動による排尿運動とは 異つた所見を得ている.

Hanley ${ }^{48}$ は Marconi image amplifier 紹介し, 逆行性腎孟像で臥位より立位をとるこ，腎杯は急に 運 動增加し造影剂は数秒間に腎孟内加排泄されるを見 て，造影剤の比重が排泄に及法す影響に注目している。

Catel (1957) ${ }^{25)}$ は 4 名の学童に就いて, その排泄性 腎盂胦画像を観察した結果，腎孟及び腎杯には真の蠕動 波は認められず, 単に Tonus の変化として観察される と報告している.

腎杯では, flimmernde od. pendelnde と表現される 所の肉眼で追う事が出来ない程頻発する運動があり, 連 続印画を作製してその腎杯円蓋部で Sphincter papillae sup. そSphincter papillae inf. の高さで横径を計測 し, ${ }^{1} / 16 \sim 5 / 16$ 秒の収縮期已 ${ }^{2} / 16 \sim 5 / 16$ 秒の弛緩期を認め 円蓋収縮極期では 2.5 3 mm, 弛緩極期で 3.5〜 4.5mm を示したと述べ, この収縮と弛緩を区別出来る律動的運 動が起つて集合管から 円蓋部への尿排出を助けると云 う考え㳊疑なく支持されると述べている. 腎杯䅡部では Pendelrythmus の外に分節状絞約と線状陰影消失があ り，分節形成活常に完全な内腔閉鎖を来たすとは限らな いとし, 腎䀤の運動は, 求心性縮小を来たす強力な緊張 增加があつて, との㭙上, 中, 下の 3 腎杯又は少くと も上, 中の 2 婜杯は腎杯腎盖開口部筋が収縮閉鎖してい るので腎孟内容は尿管へ駆出されると述べ, 腎孟の求心 性収縮は尿管起始部の閉鎖を伴い, その後腎杯腎孟移行 部の括約筫が弛緩するために腎杯内への尿逆流が見られ たと報告している. また上記の運動に上る尿運搬機序を 3 つに大別して, 1）腎杯, 腎孟, 腎孟尿管移行部に狭 险化又は閉鎖が全く見られない時に円蓋部に Pendelrythmus が見られ，てれは持続的に行われて糸毢体滤過压 を助けて乳頭集合管からの尿排出には効果的であるが, 尿管への駆出には最も効果が少い，2）肯孟の同心性収 縮と，3）上, 中腎杯系と下腎杯系と络異つた機能を示 す. 即ち上, 中腎杯が急速江收縮して内容を適度に弛緩 した腎孟を通して下腎杯系へ移す。若し下腎杯が収縮す ると逆となるが，時には 3 腎杯系がすべて同じ像を示す 
とともあり，2)及び3)は週期的汇行われて遇動数は少い がより大き駆出効果が想像されるとしている.

Bolner $(1958)^{15}$ は Lusted ${ }^{82)}$ 飞同様本法飞批名被

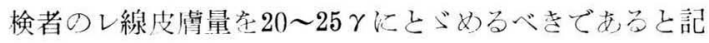
し, Narath ${ }^{99}$ の上部尿路運動在支持し, 督杯相互の運

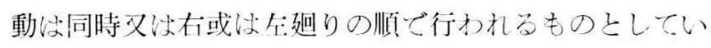
๖.

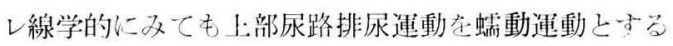
者, 之を否定寸る者の外に, 分節的括約筋協调遇動が存 在ナる等多くの所見々学説が登げられて招り, 連動の起 因も尿管蝡動在 Engelmann ${ }^{33)}$, Wharton ${ }^{138)}$ 等

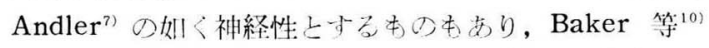
生刍 ${ }^{58}$ 㹥自律神経支配を受けていると述べ, Oekono$\operatorname{mos}^{103)}$ は上部尿路の尿による機械的並びに化学的刺战 に上る寻骮反射七するもの, 之に反し外的神経支配在否 定与る Lapides $^{78)}$, Johnson ${ }^{64)}$ 等むあつて, 上部尿路運 動には未だ定説となつているもの弥ない小うである.

\section{III 研究方法}

〔1〕レ線咉画撮影装置 (第 3 図)

1) 上線発生装置 島津平安号 三相交流, $1000 \mathrm{~m} \mathrm{~A}$ 型

2） ᄂ線管球 島津廻転陽極管球

3）上線像増倍管フフィリップス社製内径 5 时

4) 撮影機 ボレックス $\mathrm{H} 16$ motor-drive

Switer 1.4 , f $25 \mathrm{~mm}$

5）フィルム サクラ $\mathrm{SSS} 16 \mathrm{~mm}$ フジレ線間接用 $16 \mathrm{~mm}$

〔2〕撮影手技及び観察法

研究の対象とした症例は, 予め得られた排泄性腎盂像 で腎杯分岐の比輍的明膫な者で，す心゙て尿中蛋白陰性， 尿沈椬に病的所見を認めない18４5才の男女，4例を選 び, 撮影直前の食事の久禁じて水分摂取は制限を加え ず, 利尿状態の激変を避けた。

撮影前, 全例共経膀胱的に Ch 4 号尿管カテーテルを 腎孟季で挿入し, 撮影に当りレ線像增倍管の䖢光像を透 視しながら，70\%ウロコリンを徐々に逆行性に注入し た. 注入量は, 卧位 $3.0 \mathrm{cc}$, 立位 5.0 c c 以下で各腎杯系 を造影出来る最少量にとぶめた. 造影後極めて徐从に尿 管カテーテルを抜去して尿管カテ、リスムス, 並びに造 影剤注入の影響を出来る限り回避するよう留意した.

撮影条件は, 2 次電圧 60 K.V., 電流 1 $4 \mathrm{~mA}$, 被

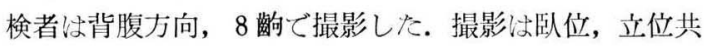

1 2 分間連続して撮影後, $3 \sim 5$ 分後の排尿運動営撮

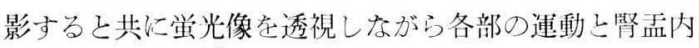
造影剤の消失時間を钼察した。

第 3 図レ線胦画撮影装置

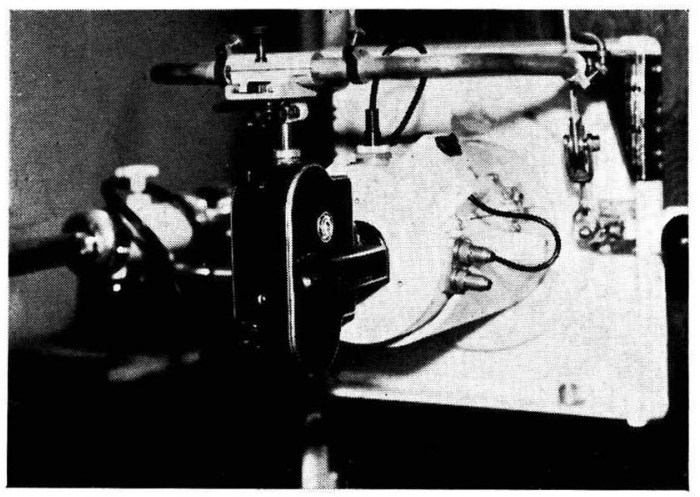

第 4 図 横径計測部位

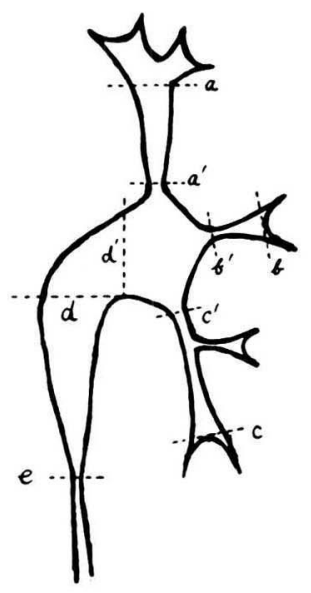

撮影された排尿運動像は，呋写に上り再現して運動の 推移を観察し，更に $16 \mathrm{~mm}$ 用 Viewer を使用して一菊每: 飞腎杯，腎孟，上部尿管の収縮弛緩運動学分析吉总以外 に, Viewer 及び咉写に上る観察中著者の主観に上る影 響孛除外するためと, 各腎杯系, 督盂及び腎孟尿管移行 部の収縮時相の関係を一層適確に知るために計測法を試

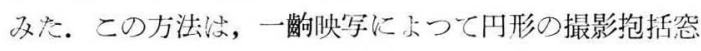

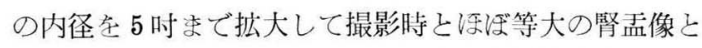
し, 第 4 図に示したように映写板上の各部横断径をコン パスで計測した。

計測は臥位，立位共腎孟の収縮弛緩運動を中心に，80

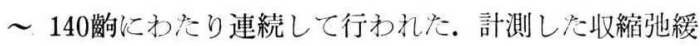


第 5 図

a. 第18戟

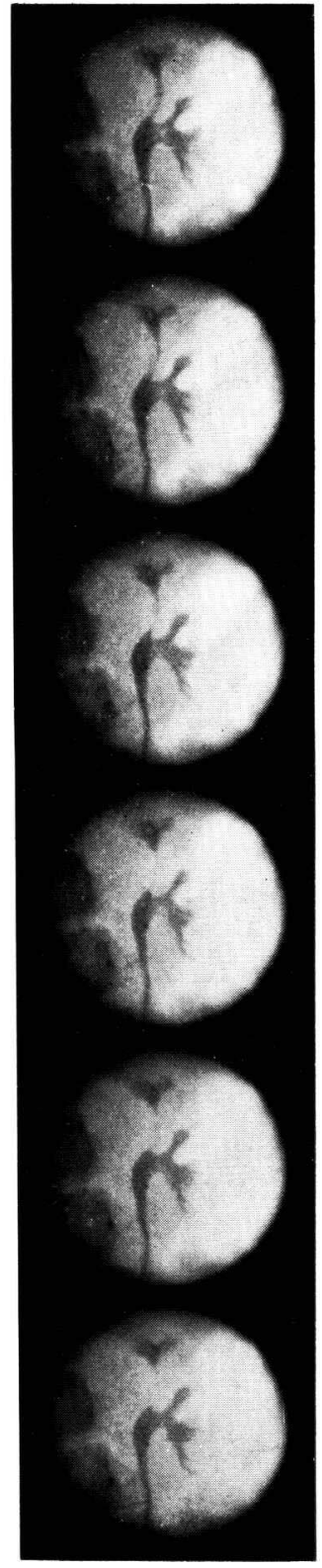

b. 第26䀞

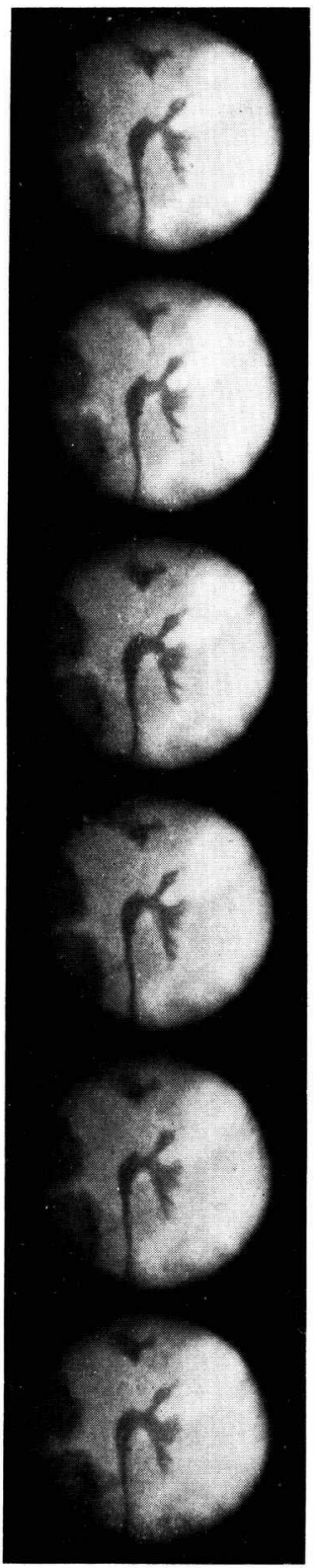

a. 腎杯収縮期，上腎杯頝部収縮離断

b. 腎孟収縮期，下腎杯へ逆流

c. 腎孟尿管移行部収縮期，上腎杯，腎孟の弛緩期

d. 腎孟尿管移行部弛緩期，腎孟の弛緩に従つて逆流払張した下腎杯は縮小を走す。 d. 第 41 龊
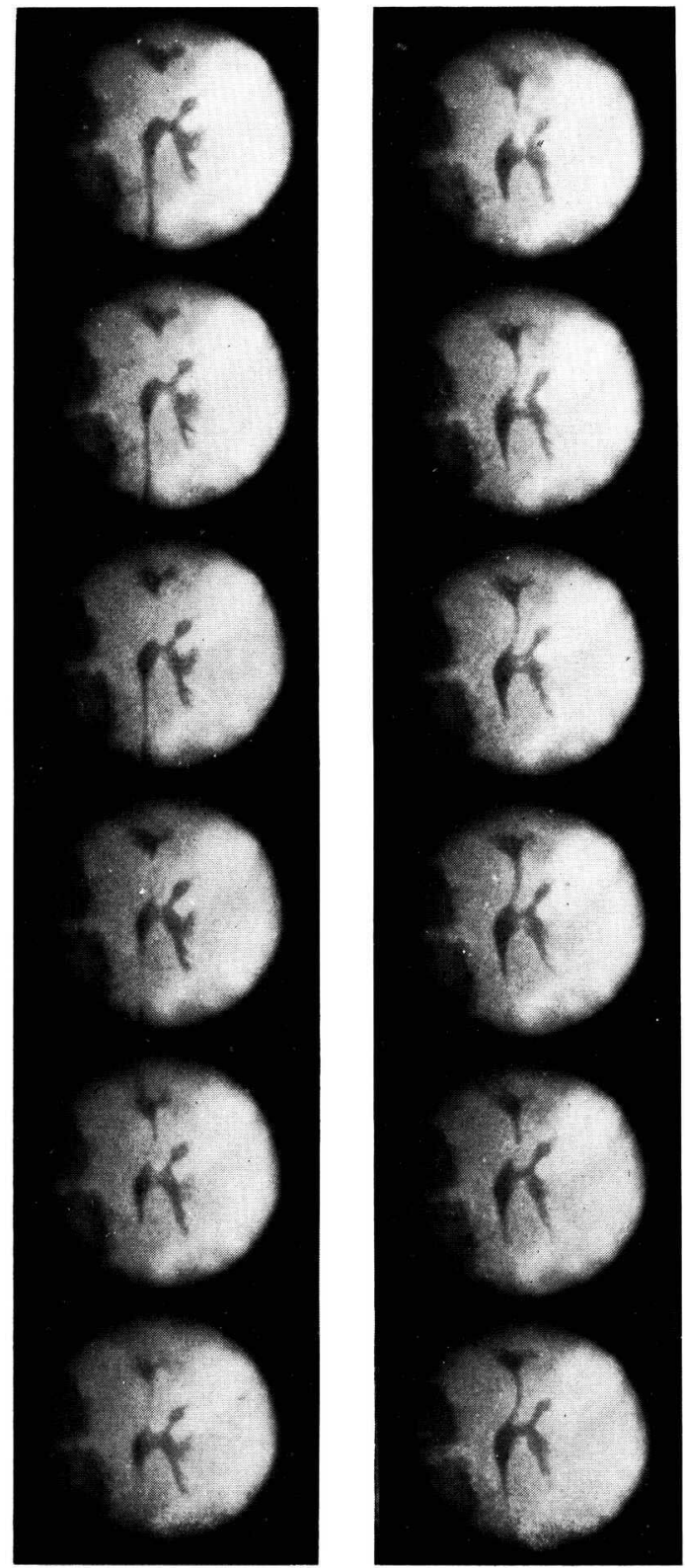


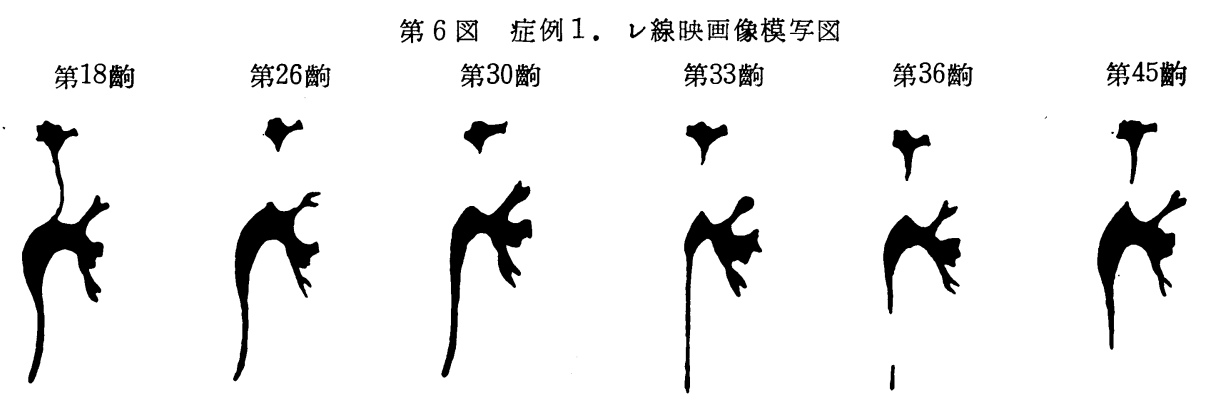

第 7 図 計測値. 症例 1 . 臥位

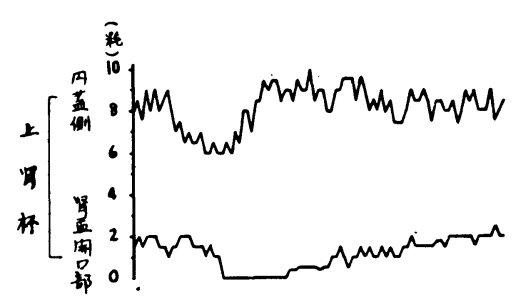

側と記し，中腎杯怡単独で腎孟に開くものを計測した。

腎孟は腎孟㓐下壁のなす凸面の最高点より外方の腎孟 漏斗部へ引いた水平断（d)を計測したが，第 4 例は水平 漏斗部が長いため垂直断 $\left(\mathrm{d}^{\prime}\right)$ で計測し, 腎孟の運動時相 を代表した.

使用したレ線像增倍管の被写体抱括空は 5 时で，腎 杯，腎孟像の撮影に岏充であるが，同時に撮影される 尿管像は, 腎孟尿管移行部より下方約 1 腰椎体幅 で，全尿管の撮影が不可能であるばかりでなく尿管運動 を主とする時怯, 腎杯, 腎孟との運動時相の関係を明ら かにし得ないので, 今回は上部尿管の運動は腎孟尿管移 行部の観察を主とした。

\section{IV 自験例}

症例 1.18才，女子, 左腎

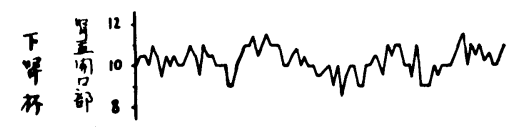

撮影台上仰臥位で左腎を透視しながら，70\%ウロコリ ンを徐々に逆行性に注入すると，腎孟に達した造影剂法 初め小球状となり更に注入量を增加すると，腎孟の全腔 を満をす前に上腎杯に流入して円蓋部より腎盂まで連続 した全腎杯像を現わした。注入中も上筒杯上り腎䀃に向 了強い収縮が見られ，との収縮が上部尿管に移行するに 従つて造影剂の一部は尿管と尿管カテーテルの間隚を下 方へ流出するのが認められた，ウロコリン $2.0 \mathrm{cc} の$ 注入 で中，下腎杯の順に造影され，下腎杯は第 2 腰椎下縁の 高さで円蓋部まで鮮明な像を現わし，腎孟，尿管む弛綏 状で完全な腎孟像を認めた後, 徐々に尿管カテーテルを 拔去した。

抜去 30 秒後から撮影を開始し, 得られた運動像を第 5

による值の增减を縦軸にとり, 聝数即ち時間の経過を横 軸にとつて比較した。

腎杯圢円蓋部乳頭先端の高さ（第 4 図 b.c.）と, 腎杯 腎盖開口部 $\left(a^{\prime}, b^{\prime}, c^{\prime}\right)$ の 2 カ所で計るを原則とした が, 大腎杯の先端円蓋側は屡々 $2 \sim 3$ 二の小腎杯が集去 り, 単独の円蓋部を示さないものは, 円蓋部に近い大㹂杯 の小腎杯分岐部での横断径 (a)を計測し, 図表には円蓋

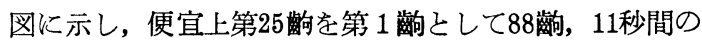
撮影像を前述の方法で計測し，第 7 図とした。 この症例 の下腎杯円蓋部は計測点の決定が困難なため計測せず腎 盖開口部のみとした。

腎杯の運動

上腎杯円蓋部。 ${ }^{10} / 8$ 秒時円蓋部先端から収縮が開始さ れ横径の短縮となり， ${ }^{13} / 8$ 秒収縮が継続して $6.0 \mathrm{~mm}$ 幅を 
示した後弛緩し始め, 1 秒の弛緩期の後に $9.0 \mathrm{~mm} の$ 休止 期となつている. 円蓋部の収縮は内沿の縮小のみで閉鎖 はなく, 収縮緊張は腎盂側へ移行して腎杯頚部の収縮に 連続している（第 5 図a.b.).

上腎杯腎䀃開口部. 円蓋側の収縮心ら $4 / 8$ 秒居れて腎

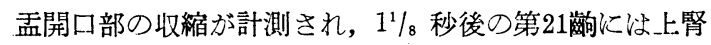
杯と腎盖は完全に離断された。この離断を示した収縮極 期は $1^{6} / 8$ 秒間持続した後, 円蓋側より弛緩し $1^{5} / 8$ 秒の弛 緩期を示して休止期となつている．との腎杯䅡部の収縮 は頝部全長に亘つて側方よりの狭险化として認められ, いずれにも輪状絞約は認めていない.

中腎杯

円蓋部では上腎杯と同様 ${ }^{10} / 8$ 秒時より収縮が開始され ている. 1 秒間収縮を持続した後, 次第に扯張を示し, 更に $1^{1} 1 /$ 秒後には急に拡張恃著明となつているがこの間 にも強い収縮を混入している。腎盐開口部出円蓋部ょり 4/8秒执くれて收縮を開始し，上腎杯䅡部と同期である.

$17 / 8$ 秒後には $2.0 \mathrm{~mm}$ 幅を娍じて最小值の $2.0 \mathrm{~mm}$ つ極期とな り更に $17 / 8$ 秒持続して弛緩期に移行している. 円蓋部の 拡張は腎盂収縮に一致して抢り, 腎孟内容の逆流による ものと思われる.

\section{下腎杯}

円蓋側は $10 / 8$ 秒後兮ら収縮を開始し, $14 / 8$ 秒の縮小を

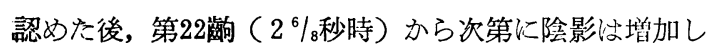

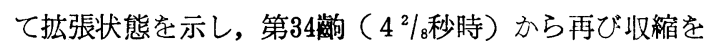
認め第50敵 ( 6218 秒時) 収縮極期となり, $5 / 8$ 秒の弛緩期 を経て休止期に移行している.

腎盖開口部は円蓋部より $1 \frac{1}{8}$ 秒 打くれて収縮開始が 見られた. この収縮は $1 / 8$ 秒続いて円蓋部と同様拢張があ

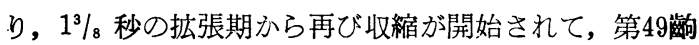
（初めの収縮開始より $3^{6} / 8$ 秒後）休止期の10～11 mm幅か ら最小値の $8.5 \mathrm{~mm}$ 幅となつて亚杯内容を腎孟に排出して いる(第 5 図 d). $1^{3} / 8$ 秒間の弛緩期を経過して休止期 聄行している.

\section{腎孟の運動}

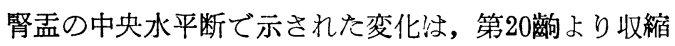
が開始され, $1^{1} / 8$ 秒後の第 29 满句では $5.0 \mathrm{~mm}$ 横径を短縮し て収縮極期となり， ${ }^{2} / 8$ 秒間収縮極期を持続して弛緩し, $24 / 8$ 秒の弛緩期を示した 後休止期となつている. 即ち $13 / 8$ 秒の收縮期と $24 / 8$ 秒の弛緩期を認めた.

腎孟の収縮は各腎杯系の円蓋部の収縮開始より $1^{2} / 8$ 秒, 腎孟開口部の収縮では上, 中腎杯 $6 / 8$ 秒, 下督杯 $1 / 8$ 秒遅れ て開始されて抢り，腎䀃開口部の収縮に連続して行われ
る状態は, 第 5 図の写真でょく示されている.しかし, 下腎杯よりの収縮の移行は明膫ではなく, 上腎杯側より 腎㙉上壁の収縮が明膫である(第 5 図 b). 収縮極期に至 つても腎盎内腔は縮小のみで閉鎖には至らず，紡鍾形の 陰影を残し（第 5 図 b.c ），収縮が腎杯側より 尿管側へ 蠕動的に移行して弛緩も収縮と同様腎杯側から尿管側へ 伝えられている(第 5 図 c.d).

腎孟尿管移行部の運動

腎孟尿管移行部恃，休止期造影剂で満され腎孟と上部

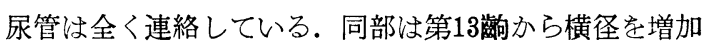
し, 最大值 $3.2 \mathrm{~mm}$ 幅を示した。これは各腎杯系円蓋部の 収縮進行に平行して增加しているので尿路内容の駆出の 結果と考えられる. 第23䨖では休止期の $2.0 \mathrm{~mm}$ 幅となつ ているが既に開始された腎孟の収縮に引続いて緊張を開 始しているととは，尿管の蛇行が減じて直線状を示す (第 5 図b) 像から推察される. $36 / 8$ 秒時より急速に収縮 し 5 秒後第 36 䋦句で収縮離断された（第 5 図C），2 秒間 の収縮期を示した後, $2^{1} \frac{1}{8}$ 秒の弛緩期を経て再び休止と なつている.

腎孟尿管移行部の運動は, 腎孟より蠕動収縮として移 行し, 腎孟の収縮極期学過ぎて尿管移行部の収縮極期之 なり，収縮は更に上部尿管へ蠕動的に移行して弛緩もま た腎盖に連続して上部尿管へ移行するのであつて, 該部 で独立した 輸状絞約乃至括約筋様収縮 は認めていない (第 5 図 d).

\section{腎杯, 腎孟, 腎孟尿管移行部の関係}

各腎杯系は円蓋部で同時に収縮が開始されたが，この 時期には腎盂，腎典尿管移行部は弛緩休止期で収縮緊張 が全く見られない，腎杯円蓋部の収縮は蠕動的に腎孟開 口部の収縮となり更に腎孟の収縮に連続しているので， 腎杯の収縮開始恃すべて腎孟の収縮に先行している.

腎孟の収縮に伴つて中腎杯円蓋部，下腎杯に腎孟内容 の一部は逆流して収縮進行途上から急激な拡張となり， 腎孟の驰緩後再び収縮するので腎跙の 1 回の収縮運動に ·対して 2 回の腎杯に扮ける収縮像として観察される。逆 流内容を排出する腎杯の運動汹, 乙の時督孟尿管移行部 の収縮期又以直後に相当し, 腎掹の弛緩に平行して行わ れるので膀胱側への直接の尿排出には関係なく反忘的な 収縮と見るのが妥当と思われる。

之に反して上腎杯腎孟開口部は, 腎跙の収縮極期後ま で収縮離断しているが，円蓋部及び頝部は既に弛緩期に あつて腎㙉に向い弛緩が進行して行く像が見られる（第 5 図bより C）また開口部で特に絞約性收縮を認めて招 
らず結果的には逆流を見なかつたが，逆流阻止の機序が あるようには考えられず, 蠕動収縮波の通過する一過程 と見るべきであろう，腎㙉尿管移行部怯，腎杯収縮に伴 つて休止期より拡張が見られるので尿路内容の移動が行 われる事が判明し，尿管への尿排出が腎盂の及ならず腎 杯の運動も直接関与する事実を知り得た。該部の収縮極 期には, 弛緩した上腎怀と逆流内容を排出する収縮像を 示す中, 下跙坏が認められた。

\section{呼吸運動との関係}

第 7 図に示した週期的收縮通過後, 休止期となつてい る第63㪤上り第75磷に至る間圢, 吸気に相当し、腎の下 方移動に伴つて中, 下腎杯系と, 特筒盂何等な縮小 が認められ，呼気棌る上腎の上方移動に従つて縮小汢 消失した。計測上, 下腎杯, 腎孟飞急激な収縮となつて 現われている。この時週期的収縮に見られた腎孟腎杯逆 流現象仗認められていないので, 造影剂の一部は弛緩し ている上部尿管内への压出が想像されるけれども縮小後 は再び休止期に連続し, 次の週期的収縮運動の開始とは 直接関係は認められなかつた。

\section{運動週期}

計測に上つて示された通り腎杯円蓋部に始るつて腎孟 を経て上部尿管へ中断する事なく連続して移行する蠕動 収縮運動㹤, 或る休止期間老扎いて週期的に行かれる。 その週期を最も明膫な腎孟尿管移行部の収縮離断開始時 をもつて観察すると，1 分間連続撮影フィルムで, 85 , $76,114,102$ 商で $94 / 8$ 秒から $14^{2} / 8$ 秒に 1 回の週期 的収縮が行われている。

腎搵内造影剂消失時間

$70 \%$ ウロコリン $2.0 \mathrm{cc}$ 逆行性注入，尿管カテーテル抜 去の直後から測定した。週期的収縮にょつて腎孟内造影 剂认次第に減少し, 映像は淡調となつているが, 造影済 の認められる限りでは, 収縮時腎孟像の完全消失は認め られなかった。 3 分経過後は各腎杯系円蓋部に造影剂は 島嶼状に残留し, 4 分 20 秒で腎杯, 腎孟, 上部尿管から 陰影山消失した。

症例 2.40才，女子, 左腎

仰臥位 $70 \%$ ウロコリン $3.0 \mathrm{cc}$, 逆行性注入. 尿管カテ 一テル抜去後 45 秒で撮影を開始した. 咉画像を第 8,9 図に揭載し，第15䯏よりの計測值を第10図とした。

計測の第 1 潾より 1.0 ～ $2.0 \mathrm{~mm}$ の緊張の增减を示す休 止期から上，中腎杯で収縮が開始された。

上腎杯の運動（第 8 図 1 2 )

第12莓的に至り上腎杯円蓋部で収縮が開始され側方より
縮小が見られた。 $1^{1} / 8$ 秒後の第 21 絔で収縮極期となつて, 平均 $10 \mathrm{~mm}$ の横径から最小值の $5.5 \mathrm{~mm}$ 亿短縮した。収縮極 期は $4 / 8$ 秒間継続し，第 26 絧 上り次第に弛緩した。 即ち $15 / 8$ 秒の収縮期と, $2^{2} / 8$ 秒の弛緩期を示して再び休止期 に移行している.

腎孟開口部に扎ける運動の変化は, 円蓋部収縮の進行 に従つて 2 秒時加該部に抢ける横径注增加し, 円蓋部 の収縮極期に一致して第 21 顽向では休止期より $1.5 \mathrm{~mm}$ 拡張 した。この拡張仗円蓋側の造影剤が収縮によつて急速に 腎孟内へ送り出される経過を示すものと考えられる. $2^{6} / 8$ 秒時から円蓋側からの収縮が移行して次第に腎孟開口部 も緊張が増加し， $42 / 8$ 秒時吕ら収縮による計測值の減少 が見られ， $46 / 8$ 秒時に収縮極期となつて， ${ }^{2} / 8$ 秒間持続し て腎孟開口部の軽度の輪状絞約を見せている. 次いで腎 杯円蓋側の弛緩に連続して蠕動的に弛緩をみたが，第48 销の 6 秒時には弛緩状態示ら更に急激な拡張が始末り

(第 8 図 3 ), $7 \frac{1}{1} / 8$ 秒時沁柱最大值 $9.0 \mathrm{~mm}$ 幅となつて円蓋 側と略々同じ計測値まで拡張した。この拡張法 $3^{3} / 8$ 秒間 持続して第76絔つ $94 / 8$ 秒時に休止期の $5.0 \mathrm{~mm}$ に復帰して いる.

上糆杯の運動像は, 円蓋部で収縮弛緩運動が見られた のに反し, 腎盂開口部では休止期永ら拡張一収縮一弛緩 一拡張一休止期となつて扮り, 初めの拡張恃円蓋部の収 縮の影響であり，後の拡張は腎孟（後述）の収縮による 逆流の影響上考えられる。

中腎杯の運動

第12茲で円蓋部, 腎盂開口部で共に収縮が開始され, $5 / 8$ 秒後から $1^{2} / 8$ 秒間の拡張を示し, その後も緊張が継続 している如く不規則な収縮弛緩を絽返えした。第45絧 （収縮が開始されてから $4^{1} / 8$ 秒後）円蓋部に执いて再び 拡張し, 第 51 㪤句の 6 秒後には最大值 $12.5 \mathrm{~mm}$ 米で横径の増 加をみた。 ての拡張は急速に消失して第53絔より円蓋部 で 1.0〜 2.0mm, 腎孟開口部で 0.5〜 1.5mmの緊張増減 が規則的に行われ休止期之なつている. 中腎杯において は收縮期及び弛緩期の移行注明膫ではない。

\section{下腎杯の運動}

第31敵丸り円蓋部で収縮が開始された。 ${ }^{6} / 8$ 秒間の収縮 期の継続を見たが，収縮力弱く計測上 $1.0 \mathrm{~mm}$ 幅の減少を 続けたの及で円蓋部の咉像消失には至つていない. 第 38

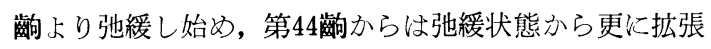

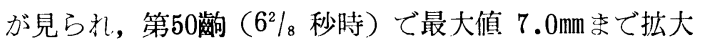
している（第8図4）.

腎孟開口部は, 円蓋部収縮開咍時には未だ休止期にあ 
1. 第 18 齙

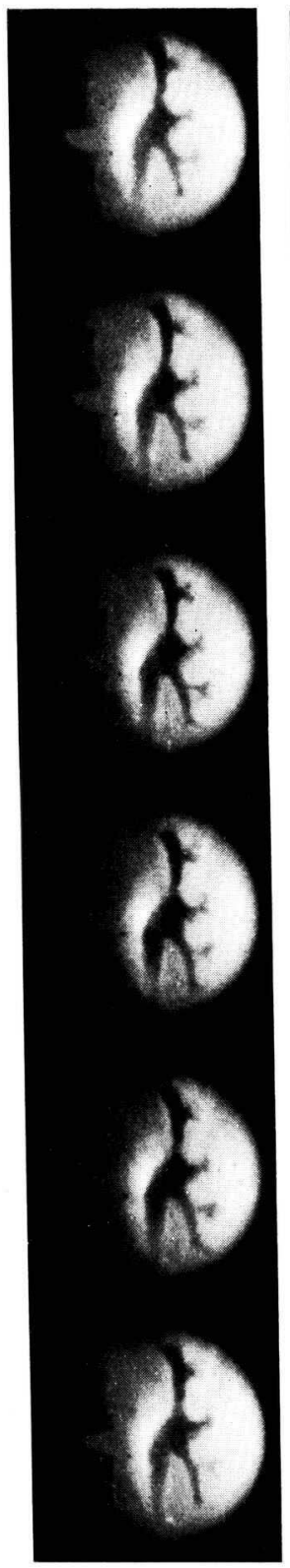

2. 第36䕬

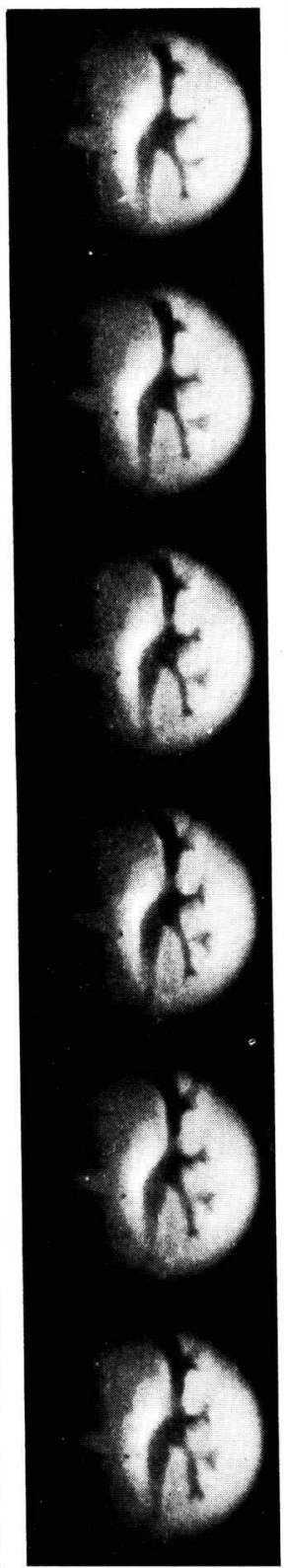

第 8 図

3. 第 43 齙

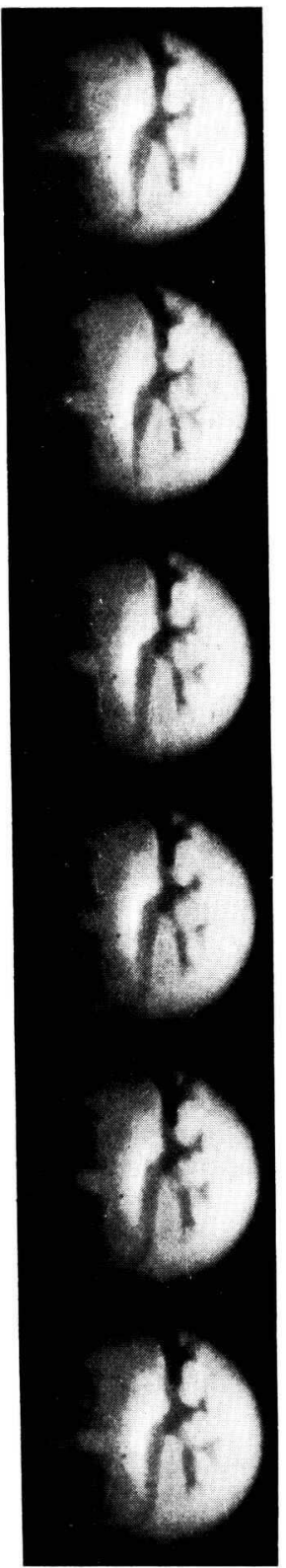

4. 第53萄

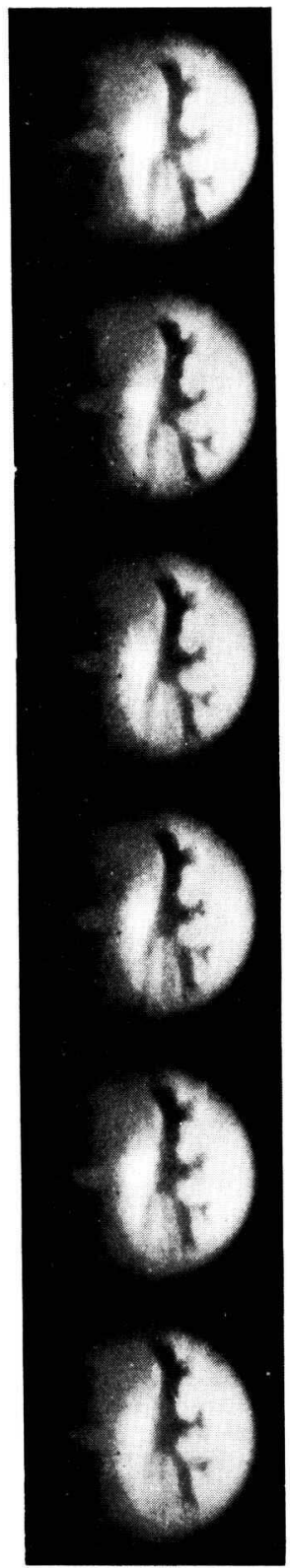

5. 第67㗕

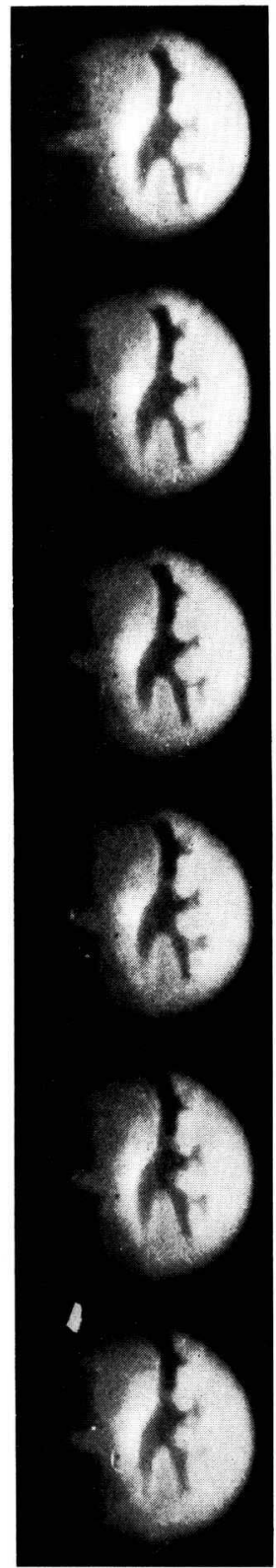

1.上, 中粲杯收縮期

2. 下腎杯収縮期

3. 腎而収縮期，上，下腎杯は逆流による挾張期

4. 腎血収縮梅期から腎孟尿管移行部の収縮期

5. 腎孟及び腎孟尿管移行部の弛緩期，上，下腎杯は縮小期 
1）第 21 莓句

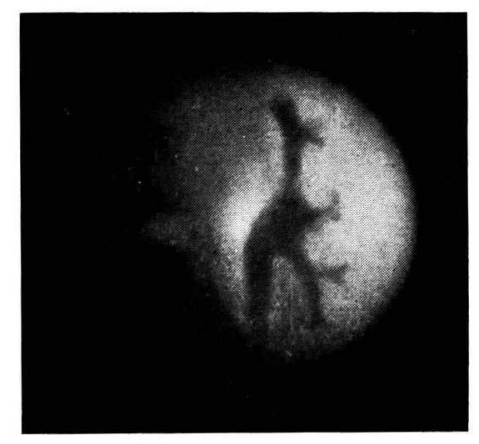

上，中腎杯の収縮

2）第35萄

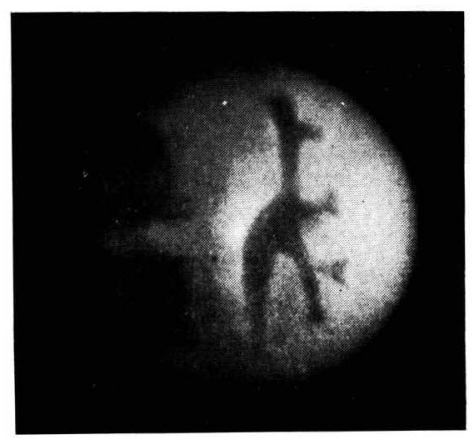

上腎杯腎孟開口部收縮

下腎杯円蓋部の収縮開始
第 9 図症例 2 附位桩大像
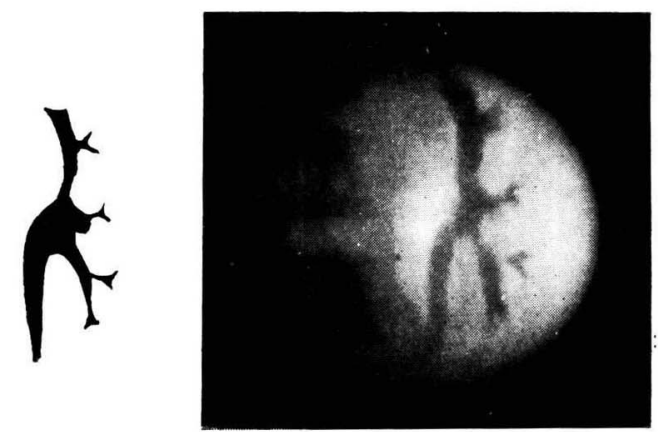

腎孟収縮極期

上腎杯野部の逆流による报張著明。

5）第60跔

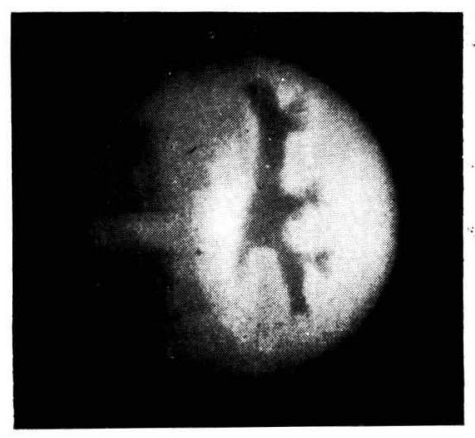

腎孟尿管移行部收縮極期 腎孟は腎杯側より弛緩

6) 第 80 鹋

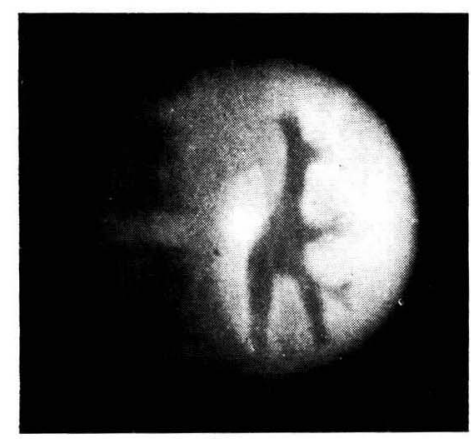

休止期

各腎杯は逆流による 拡張より縮小す

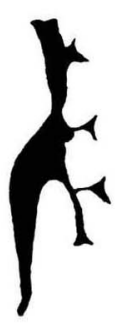$$
\text { 促 }
$$

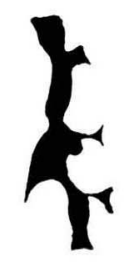

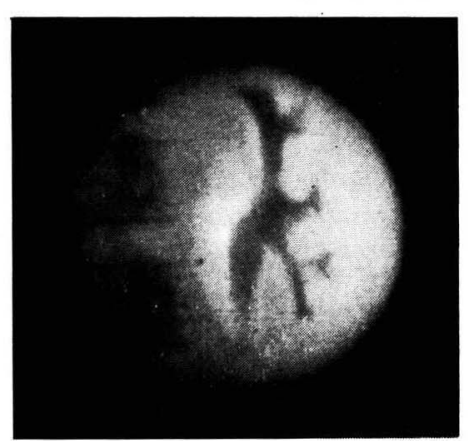

下腎杯腎孟開口部の收縮, 円蓋部弛緩 上腎杯弛緩期 腎盂收縮開始 
第10図計測值, 症例 2 , 臥位

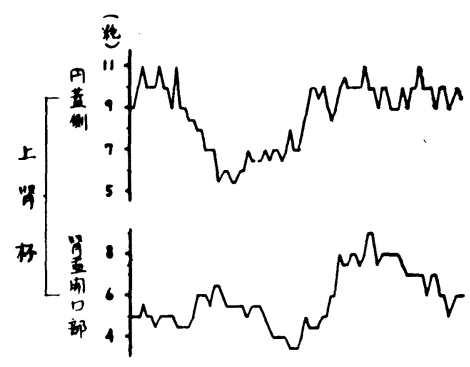

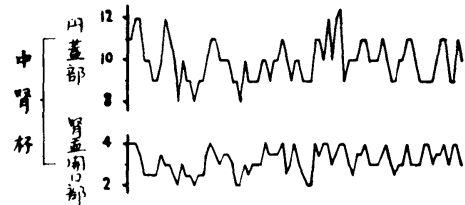
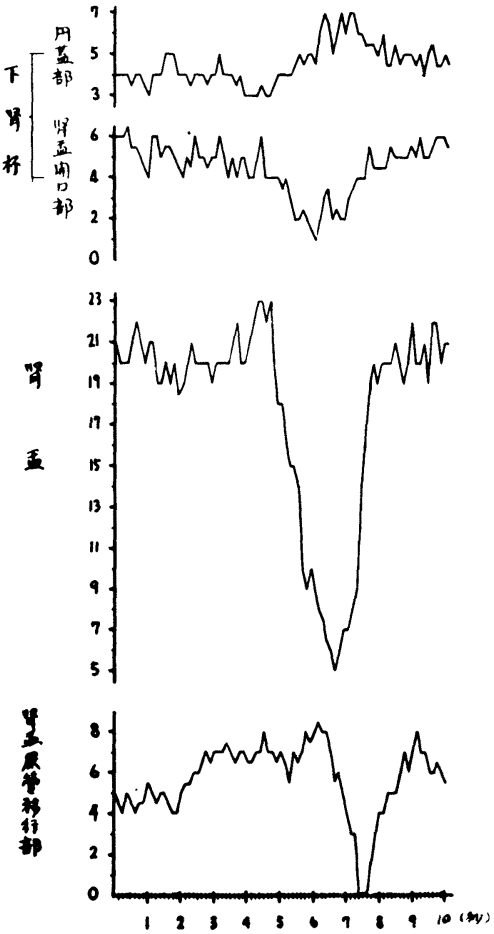

つて収縮住喼められない。円蓋部の収縮極期が終了する 第36龂から円蓋部上り腎而に向引収縮が移行するに従つ

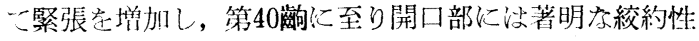
収縮が開始された（第 8 図 3 ）.との絞約性収縮は 1 秒間

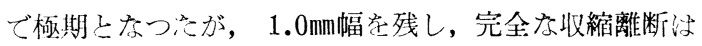
認めていない. 収縮開始後 $15 / 8$ 秒で弛䌊期に移行し $15 / 8$ 秒の阤緩期から休止期に捙続している。
第11図 計測值, 症例 2 , 立位
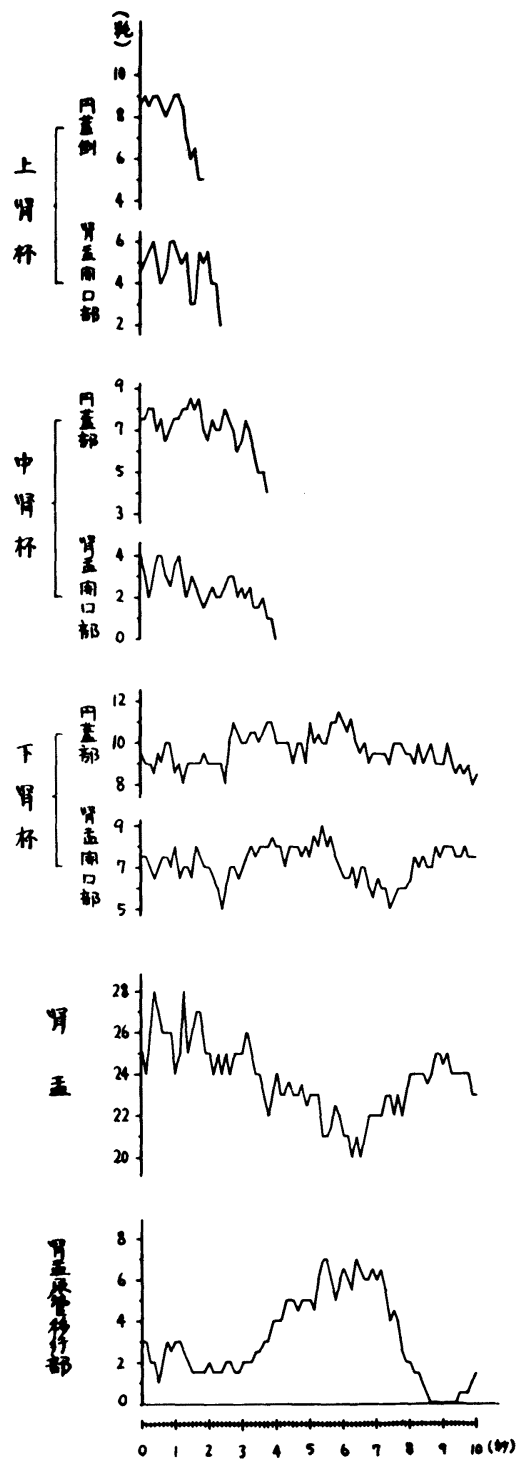

下腎杯火扎け収縮運動の経過は，円蓋部より開始さ れた收縮波が腎杯頚部省経て開口部に至る間に既に円蓋 部より弛緩が開始されて, goblet 状を呈し腎盘開口部 の収縮が腎輌に移行して弛緩すると腎杯，腎孟腔山連絡 して goblet は消失し休止期となつている。

下腎杯頚部に開口している小腎杯をみると，第38临よ り第43葋に至る間大腎杯への開口部の高さの収縮に同調 して小腎杯䅡部も収縮しているが, 離断する尔でに至つ ていない. 
小腎杯円蓋部では終始 ${ }^{1} / 8 \sim 4 / 8$ 秒の間隔で収縮, 弛緩を 繰返えしているのみで週期的収縮は明らかにする事は出 来なかつた。

第10図で見ると下腎杯も上腎杯と同様儿円蓋部之腎杯 腎盂開口部とは逆の運動相を示して交互に收縮弛緩を行 つたように現われているが，てれは第 8 図の写真で見る 如く，円蓋部より腎盂飞向了収縮波の通過による收縮時 相のずれであつて蠕動形式の収縮である。

\section{腎孟の運動}

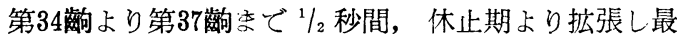
大值の $23 \mathrm{~mm}$ 示したが，乙れは督杯運動の進行に半つて

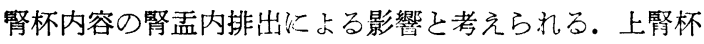
の腎孟開口部の収縮は連続して腎盘上壁の収縮運動に移 行し腎孟上壁は緊張して腎杯側へ率引され，上腎杯に捻 くれて収縮が開始された下腎杯腎孟開口部の収縮も腎盎 下壁の収縮に移行して上壁より $5 / 8$ 秒扢くれて緊張を增加 し，次第に挙上されて腎踓は上，下壁の收縮によつて内 腔を縮小した(第 8 図 3，4). 督孟中央の計測点では, 第

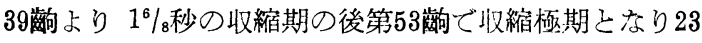
$\mathrm{mm}$ 幅から $5.0 \mathrm{~mm}$ となつたが腎㙉胿の閉塞仗認めていない.

腎孟の収縮は腎盂漏斗部の収縮心移行し, 婜盂尿管移 行部の収縮へ之連続する一方, 腎杯側卡り弛緩が開始さ れ芯（第 8 図 4，5）との弛緩も腎杯上り中断される 事なく連続して行われた。計測点では，2秒の弛緩期の

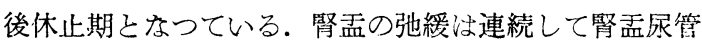
移行部の弛緩に移行している.弛綏汇胖つて造影剂沙下 降し長嘴状をなして上部尿管へ進行した。

腎典尿管移行部の運動

第18籁上り 4 秒間陰影が增強すると共に横径纱增加 し, 造影剤の尿管内への流下を思わしぬる掋張心゙計測さ れた。これは次の項で述べる腎杯, 腎孟の收縮に尗る影 響と見られる。腎孟漏斗部加連続して移行した収縮 は，第52㗭より腎孟尿管移行部の収縮となり，尿管上部 は側方よりの狭险化となつて急激に計測值は減少し, 第

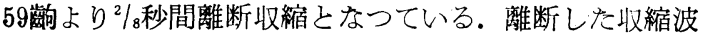
は蝡動的に膀胱側へ移動し撮影空外へ消えている。

弛緩も腎孟漏斗部から円滑に下行し, 該部で $/ 8$ 秒の弛 緩期が計測された。腎盘尿管移行部に捛いても膀胱側へ 進行する蠕動収縮運動が観察され，括約筋的収縮注認め られない。

腎杯, 腎孟, 腎孟尿管移行部の収縮運動の関係

この症例に执いても腎杯円蓋部で開始された蠕動収縮 が腎孟を通過して腎孟尿管移行部へ円滑汇移行するのが 観察されたが, この間にあつて, 婜杯の収縮開始注,
上, 中腎杯円蓋部で同時に開始され，その後下腎杯の順 に始妨られた。 上, 下腎杯円蓋部の収縮開始時性, 腎杯 腎孟開口部及び腎孟圢未だ休止期にあつて弛緩してお り，上腎杯では円蓋部の収縮によつて腎杯内容の排出の 結果腎孟開口部は弛緩より更に拡張し，これに続く腎孟 も弛緩したまつで収縮は見られないが更に下方の腎㙉尿 管移行部は弛緩より漸增的に横径增加し，下腎杯の円 蓋部での収縮が加うると腎孟も拡張して一時腎杯ょり排 出された造影剂を受入れるばかりでなく，腎盂内容は腎 孟尿管移行部走通つて上部限管内一排出されている。腎 杯運動によつても尿路内容の尿管への移行が行われるで あろうと云うととは, 腎盂の収縮が加わると一層横径が 增加する事から容易に推察出来る.

上，下腎杯の腎孟開口部収縮極期汕腎孟は収縮の途 上にあるが腎孟尿管移行部仗未だ弛緩し, 造影剤の流下 によつて拡張を示している.

腎孟収縮極期に至ると，既に休止期を示す上腎杯円蓋 部と弛緩期にある下腎杯開口部とがあり，上腎杯腎孟開 口部と下腎杯门蓋部计腎孟収縮に伴了腎孟内容の逆流が 起つて弛緩期より急激な报張を来たしている。中腎杯円 蓋部も督孟の収縮進行中に逆流現象を伴つている. 他方 腎孟尿管移行部は収縮開始の直前で，その後収縮蠕動に よつて離断が認められた時は，腎孟は収縮期を過ざて弛 緩の途上にある．乙の時上腎杯腎孟開口部と下腎杯円蓋 部㥙逆流した内容を弛緩しつ〉ある腎跙へ排出し, 縮小

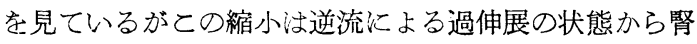
杯内容に応じた緊張度を有する休止期にもどる変化で能 動的な収縮排出運動と㹥考えられない。

腎盂尿管移行部の弛緩期より休止期になると腎杯，腎 孟结既に全く休止期となつている.

立位に招ける排尿運動

被検者を直立位とし，70\%ウロコリン $5.0 \mathrm{cc}$ を逆行性 に注入すると上腎杯まで完全な陰影を現わした，尿管カ テーテル报去と同時に撮影を開始し，臥位と同じく各部 の計測值の変化をグラフに示すと第11図のようである.

上腎杯

$1 \% / \mathrm{s}$ 秒後に汹 $9.0 \mathrm{~mm}$ 分急激に減少して $5.0 \mathrm{~mm}$ 幅之な り，腎杯胿の閉塞を来なさずに円蓋側より造影剤は流下 消失した。腎㙉開口部においては， $2^{3} / 8$ 秒後には $5.0 \mathrm{~mm}$ から $2.0 \mathrm{~mm}$ の横径の減少となり, 造影剤の下方流下のた め計測不能となつている.

\section{中腎杯}

腎孟内造影剤の流下著明で, 腎孟像の上方无らの陰影 消失に伴つて円蓋部も $3^{6} / 8$ 秒後に㳉，6.5〜 8.5mmの横 
径から $4.0 \mathrm{~mm}$ 亿減少したが, それ以上は陰影淡く不鮮明 で計測不能である.4秒後には腎杯頝部の陰影消失とな り, 円蓋部に少量の造影剤を残すのみである.

上, 中腎杯では造影剂の流出に伴つた急速な腎杯像の 消失が見られたので, 収縮運動と思われる明らかな所見 は得られなかつた。

下腎杯

$1^{2} / 8$ 秒時円蓋部で収縮が開始され， $1^{2} / 8$ 秒間の収縮期 の後急速に拡張して陰影濃度を增すと共に更に拡張して $57 / 8$ 秒時には最大值 $11.5 \mathrm{~mm}$ となつている.

円蓋部に始李つた収縮は $7 / 8$ 秒後蠕動的に腎孟開口部に 伝わり，第 19 钞の $2^{3} / \mathrm{s}$ 秒時には $2.0 \mathrm{~mm}$ 短縮 を示した 後, 円蓋部之同様弛緩払張状態となり $5^{3} / 8$ 秒時に注最大 值 $9.0 \mathrm{~mm}$ を示した. 弛緩より拡張を示した下腎杯浪，第 51 哃の $6^{3} / 8$ 秒時より円蓋部, 腎盖開口部共に縮小し, 第 65絔 $8^{1 / 1} / 8$ 秒時には共に休止期とな.つている. 収縮開始後 飞見られた拡張は，腎盘の収縮進行による腎孟内容の逆 流のため示されたものであり，円蓋部，筒孟開口部共に 休止期亦ら収縮一拉張一縮小見て休止期に移行してい 3.

\section{腎孟の運動}

腎盖では 1.0〜 4.0mmの緊張の增減宗示す休止期から 第17苇 $21 / 8$ 秒時より多少緊張を增加した如く計測值の変 動は減少した。

督孟内造影剂は弛緩している尿管内へ盛んに流下して いる如く腎孟像は上腎杯の映像の消失に連続して上方よ り陰影は消失し, 中腎杯分岐部の高さでは陰影淡調で腎 孟上壁の収縮像恃不明であるが，第26䓰の $3^{2} / 8$ 秒時下腎 杯腎孟開口部の収縮に連続して腎孟下縁の収縮となり腎 孟下壁は挙上されて腎孟漏斗部は腎杯側へ率引されつ> 収縮運動が腎杯側より尿管側へ蠕動的に移行している。 計測点では， $3 \% 8$ 秒の収縮期と $2 \%$ 秒の弛緩期を示した 後休止期に移行した。

\section{腎孟尿管移行部の運動}

第26糆より腎孟の收縮に平行して急激に弛緩拡張して

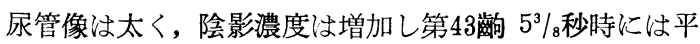
均 $2.0 \mathrm{~mm}$ から最大横径の $7.0 \mathrm{~mm}$ 幅まで拡張を見た。第 58 鈶に至り腎孟漏斗部の収縮が上方より波及すると，急速 に収縮を開始し， $8^{5} / 8$ 秒時には収縮によつて完全に離断 され， ${ }^{6} / 8$ 秒間の離断収縮を見た後腎孟漏斗部の弛緩に引 続き第76絔 $94 / 8$ 秒時には弛緩期に移行している.

腎孟尿管移行部を収縮離断している間に，収縮波は蠕 動的に上部尿管に移行して $1 / 2$ 秒後には，尿管内造影剂は
膀胱側へ排出されて撮影空外へ去り, 上部尿管像は一時 消失後, 腎勐の弛緩に連続して尿管上部より弛緩し, 腎 孟上り造影剂々゙流入して再び連続した腎孟尿管像を現わ している．腎㙉尿管移行部も蠕動収縮弛緩運動であつて 尿管上部の収縮運動々全く異る所はなく, 括約筋的独立 性の収縮は認められない。

腎杯，腎孟，腎孟尿管移行部の運動の関係

尿管カテーテル抜去と同時に造影剤の流下が著明で, 立位に抢ける上，中腎杯の収縮運動は明らかにすること は出来なかつた. 従つて各腎杯間の収縮の関係も不明で ある。

下腎杯に打ける収縮は臥位と同じく円蓋部で収縮が開 始され, 開始直後も腎孟, 腎孟尿管移行部は休止期にあ つて弛緩状態である. 円蓋部の収縮が持続している間に 収縮波は腎孟開口部に伝わり，更に腎孟の収縮が開始さ れると, 腎孟内造影剂は上部尿管へ排出され腎孟尿管移 行部の弛緩拡張は著明となる一方, 腎孟内容の一部は下 腎杯内へ逆流し拡張を惹起しているので，腎孟と腎杯及 び腎孟尿管移行部とは逆の運動像を呈している.

腎盂の弛緩期には，腎盂尿管移行部一蠕動波は移動し て移行部の収縮期を示し, 腎杯法逆流に上る拡張から縮 小を見ているので この時期にも逆の運動相を示してい る.

尿管移行部の収縮極期には, 下腎杯及び腎孟は既に休 止期となつていずれも收縮像は認められない。

立位に执いても腎杯の収縮開始は腎孟の収縮に先行 し, 下腎杯, 腎罡, 腎盖尿管移行部の順序で中断する事 なく蠕動収縮波が移動するのが観察された。

呼吸運動との関係

臥位の第15莓向で吸気による腎下降があり，1/2腰椎幅下 万に移動して腎孟の $3.5 \mathrm{~mm}$ 縮小が見られた。腎盐尿管 移行部で $3 /$ 秒間 $1.0 \mathrm{~mm}$ の短縮となつている. 乙の時吸気 に一致して上腎杯円蓋部での収縮が開始されているが, 次の週期的収縮は呼気に一致して開始されており, 呼吸 運動と収縮開始とは一定の関係は認められなかつた。

運動週期

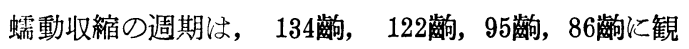
察され $10^{3} / 8 \sim 16^{6} / 8$ 秒に 1 回の収縮運動が行われた。立

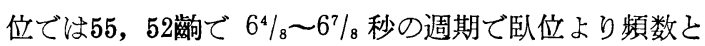
なつている.

腎孟内造影剂消失時間

70\%ウロコリンを使用したが，臥位 $3.0 \mathrm{cc}$ ，立位 5.0 ccの逆行性注入で卧位 8 分 46 秒, 立位 4 分 48 秒で腎杯, 
第12図 計測值, 症例 3 ，臥位
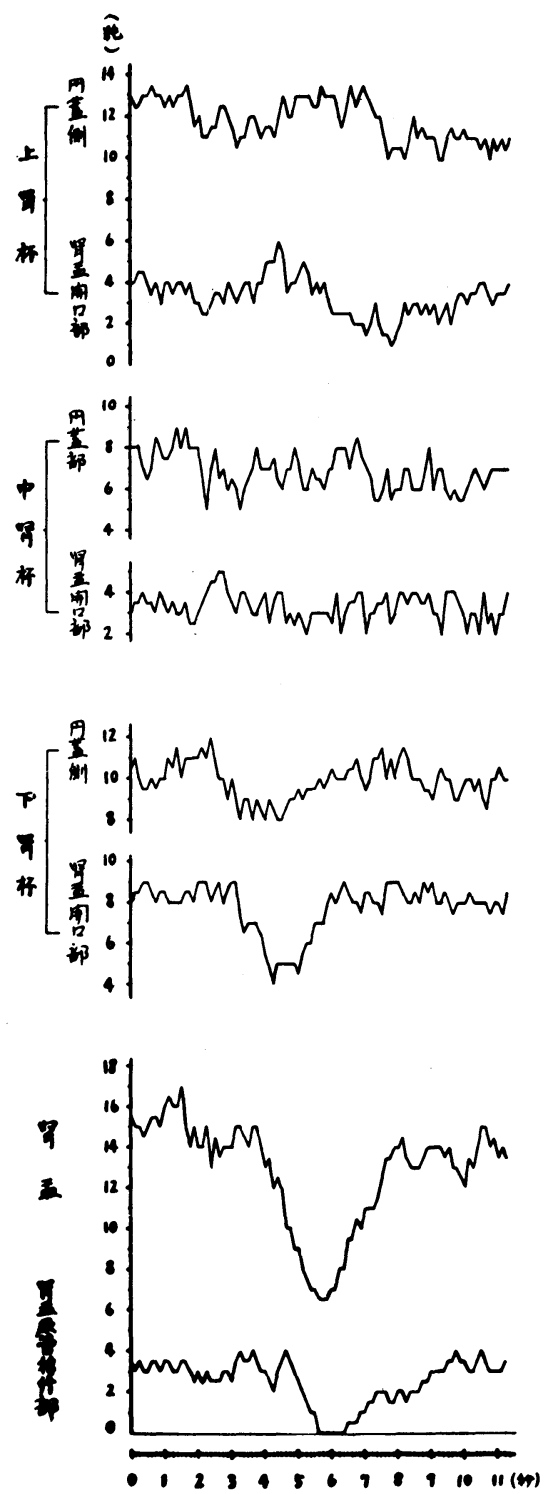

腎孟像は全く消失し，立位時には速く排泄された。 臥位，立位に打ける運動像の比較

臥位，立位共に週期的に腎杯，腎盂，尿管の順に蠕動 収縮が見られる事には相違はなく，臥位に認められた腎 孟腎杯逆流現象も，急速に排泄される立位時にあつても 認められ，大腎杯程逆流し易いが，部位は一定しない上 らである. 即ち下腎杯腎孟開口部で，臥位には逆流によ る拡張が見られなかつたが，立位時では腎盂収縮に一致
第13図 計測値，症例 3 ，立位
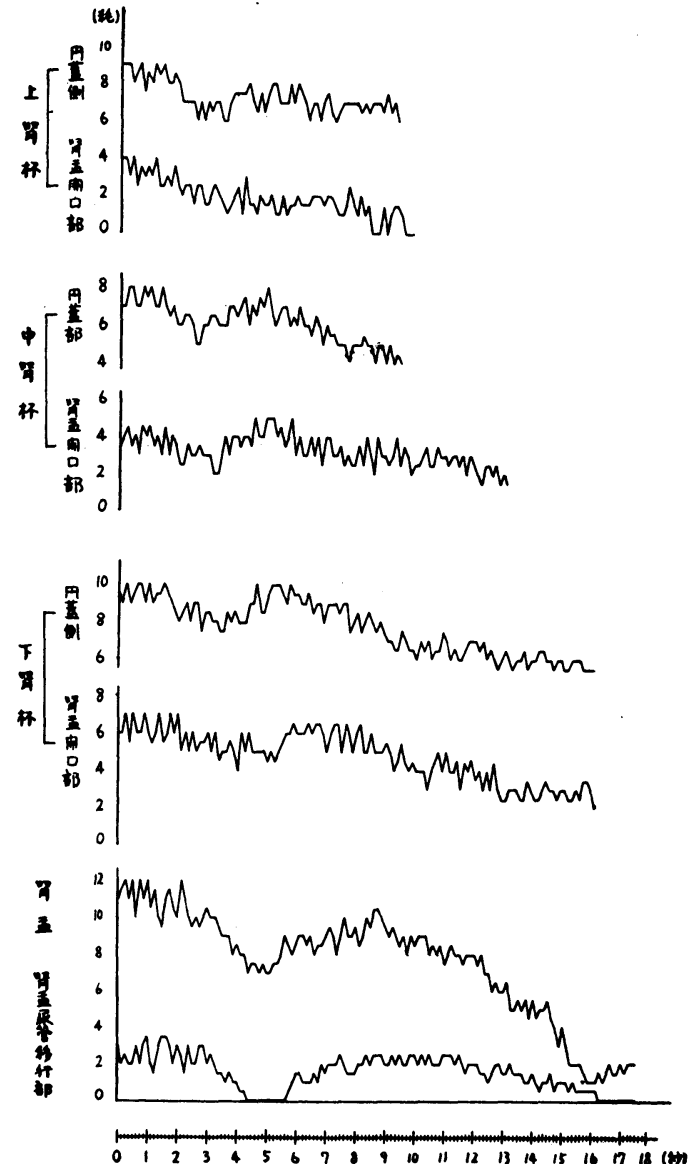

して拡張が認められたので腎孟内容によつて変化するよ うである. 立位㭙に下腎杯への逆流が著明であつた事 と，下腎杯内の造影剤貯留が排泄時間の対象となつた事 は，造影剤の比重を考虑しなければならない現象とも考 えられる。

この症例の各部に抢ける収縮の大きさと収縮運動の時 間を見ると，臥位では計測值の変動㹥急峻で且大きく， 立位ではより緩徐で小さい傾向がある。この関係は腎孟 の計測值で明膫に示されている。また下腎杯円蓋部で収 縮が開始されてから腎孟尿管移行部の収縮終了までの時 間を測ると, 臥位 $3^{6} / 8$ 秒, 立位 $8^{1} / 8$ 秒を要し, 立位て は 2 倍強の収縮時間で緩徐飞行われており，運動週期は 逆に立位では短縮されている。

症例 3.23才，女子 左腎 
仰臥位, 70\%ウロコリン 2.5cc逆行性注入. 尿管カテ 一テル抜去して30秒後より撮影を開始した。第60钧を計

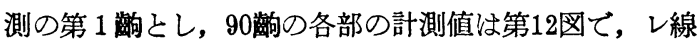
映画像は第14図である.

腎杯の運動

上腎杯

第14满句の $1^{6} / 8$ 秒時円蓋測で収縮が開始され，側方より 縮小して $1^{3} / 8$ 秒間持続し, 第 25 㪘から徐々に弛緩拡張し た。 この拡張は逆流によるものと思われ陰影の濃度は増 加している. 拡張した円蓋部は $7^{1} / 8$ 秒時再び収縮を開始 して腎杯内容を腎孟へ駆出し，休止期の平均 $13 \mathrm{~mm}$ から $10.5 \mathrm{~mm}$ に縮小し $4 / 8$ 秒間収縮極期を持続した後弛緩休止期 となつている.

腎盂開口部では円蓋側より $1 / 8$ 秒遅れて第 15 销より $4 / 8$ 秒 間に $1.0 \mathrm{~mm}$ の狭险化を示した。 この収縮は腎杯頝部の全 長にわたる収縮で特に絞約性収縮は認めず，単に緊張の 増加と見られる程度である。その後 $/ 8$ 秒間の弛緩期を経 て休止期の $4.0 \mathrm{~mm}$ 示したが, 第32踹から急激に拡張し て開口部及び円蓋側の陰影な增強し，顕著な逆流現象を 見た。逆流によつて拡張した開口部は弛緩拡張したま > ではなく，てれに拮抗する如く $1 / 8$ ～ $2 / 8$ 秒の著明な收縮他 緩運動を行いつ〉, $5^{7} / 8$ 秒時より搪張せしめた腎杯内容 を排除するょうに再び収縮運動が始まり，初めはや>緩 徐に $24 / 8$ 秒間続けられ収縮極期は円蓋側の極期と一致し て上腎杯全長の狭险化を示した後 2 秒の弛緩期を経て休 止期となり，逆流現象牥下腎杯收縮極期之腎孟収縮の進 行と一致していた（第14図，(口）).

中腎杯

円蓋部で，第14絔より $14 / 8$ 秒間収縮を示したが，その 間にも著明な緊張の增減があつて円蓋部の陰影消失は認 められない. $34 / 8$ 秒間拡張の傾向を認め, その後上腎杯 と一致して縮小があり休止期に移行している.

開口部では明膫な収縮開始仗示さず，第16敵つ 2 秒時 に急速な拡張が始まり，1秒間継続した後に次第に縮小 の傾向があり，第41䕬から 1 秒間の弛緩期を経て休止期 となつているが, 映写による観察のみでは各運動期を明 らかにする事は出来なかつた。

\section{下腎杯}

第20满の $24 / 8$ 秒時, 下極先端の小腎杯円蓋部より収 縮が開始された（第14図口）.収縮は腎孟へ向い， $\% / 8$ 秒後 の第26瞄では腎孟開口部の収縮に移行し, $42 / 8$ 秒時には 円蓋部，腎孟開口部共に収縮極期となつて下腎杯全長が 収縮して腎杯内容を腎盖へ排出した後, 円蓋部より次第
に弛緩して腎孟開口部も弛緩を示した。

円蓋部では収縮開始前に上腎杯の収縮によつて逆流に よる拡張を見をが，第51爾の $6^{3} / 8$ 秒時にも上腎杯の収縮 に平行して下腎杯に逆流のための拡張が見られ， $1^{7} / 8$ 秒 間拡張した後休止期に復帰している。腎孟開口部では収 縮弛緩運動を示したのみで逆流による拡張性認められな W.

\section{各腎杯間の運動の関係}

上，中腎杯円蓋部は同時に第14絔で収縮を開始し，下 腎杯円蓋部は 6 秒後收縮を開始している。その収縮は螦 動的に腎盖開口部の収縮となつているが，中腎杯に打い てはこの経過は明膫ではない。 下腎杯では, 上腎杯の収 縮進行に伴つて初め腎杯腔の拡張となつて現われ，下腎 杯の収縮と腎盂の収縮とが加わつて上腎杯への逆流によ る拡張像となり，督孟弛緩期に上腎杯は逆流内容を排出 する収縮が再じ行われて，その影響は下腎杯円蓋側の拡 張となつている(第14図二).それ故上腎杯と下腎杯と性 休止期から交互に收縮弛緩を行つた如く 3 回の全く相反 する運動時相を示した後，次の週期的収縮運動が開始さ れるまで休止期となつている。この腎杯間の運動像の関 係第12図の計測值の比較で明らかにされている.

腎孟及び腎孟尿管移行部の運動

腎杯円蓋側から開始された収縮運動牥，腎杯腎孟移行 部兮ら連続して腎孟の収縮に移行し，腎杯側の腎盂上， 下壁の収縮緊張となつて現われている。腎盖の腎杯側よ りの収縮俚下方へ移行し, 腎孟漏斗部も上方六ら尿管側 一蠕動的に伝えられ腎孟内容を上部尿管へ排出すると共 に下腎杯側に引き寄せられ，極期には求心性の縮小とな つている. 計測点では第 31 㪤加ら $2^{1} / 8$ 秒間の収縮期を示 して平均 $15 \mathrm{~mm}$ から $6.5 \mathrm{~mm}$ に短縮したが完全な腎孟腔の閉 塞性見ていない（第14図八）. その後 2 秒間の弛緩期を経 て休止期となっている. 弛緩も腎杯側から尿管側へ移動 している.

腎孟漏斗部の収縮は中断する事なく蠕動的に腎孟尿管

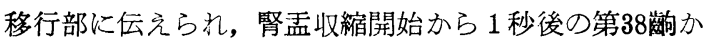
ら収縮が見られ， $7 / 8$ 秒の収縮期の後腎孟尿管移行部は閉 鎖離断された（第14図八）。

腎孟とこれに扝くれて収縮を開始した腎孟尿管移行部 とは $5 \frac{5}{8}$ 秒時から $2 / 8$ 秒間同時に収縮極期を示した後, 腎盘で弛緩が先行し蠕動的に尿管移行部の弛緩となつて いる. 腎孟では $2^{1} / 8$ 秒の収縮期と， 2 秒の弛緩期，腎孟 尿管移行部では， $1^{6} / 8$ 秒の収縮期と， $2^{3} / 8$ 秒の弛緩期の後 
1）第20歯
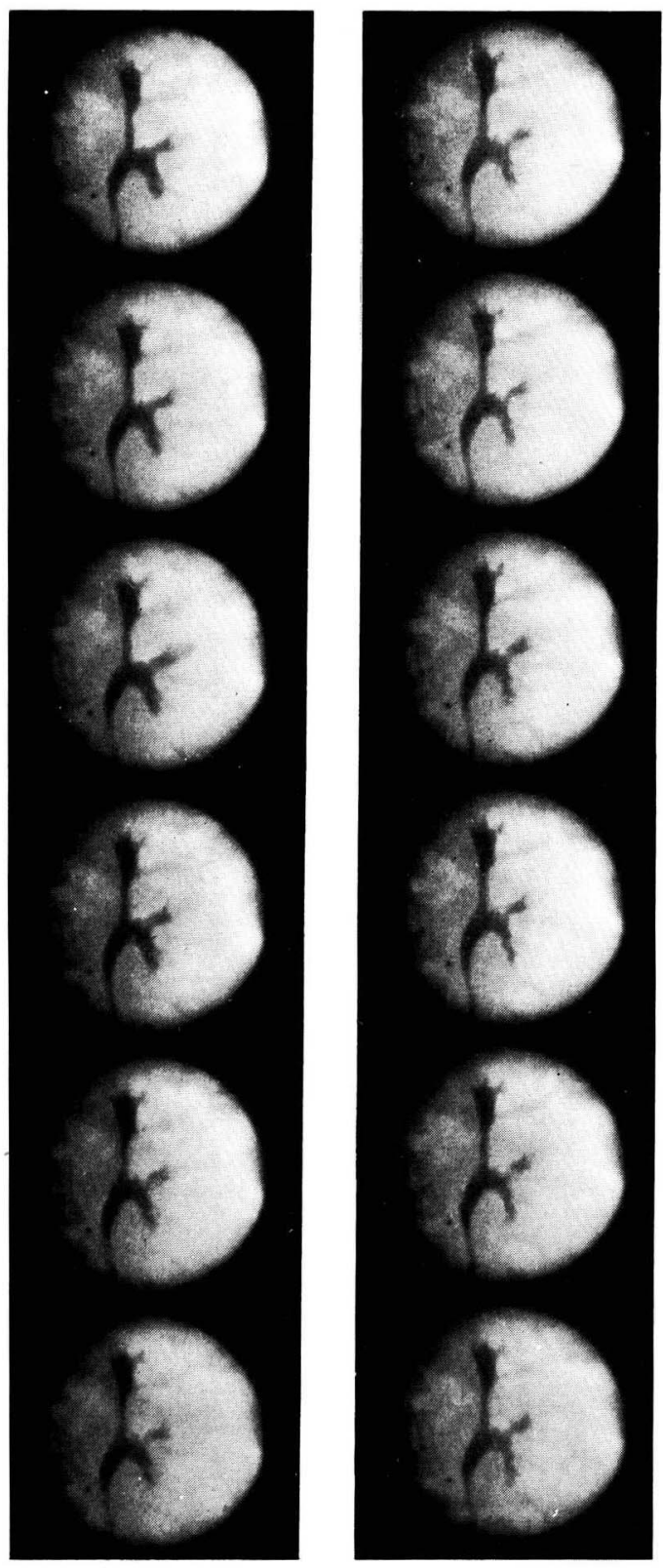

口) 第31鹋

第 14 図

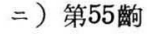
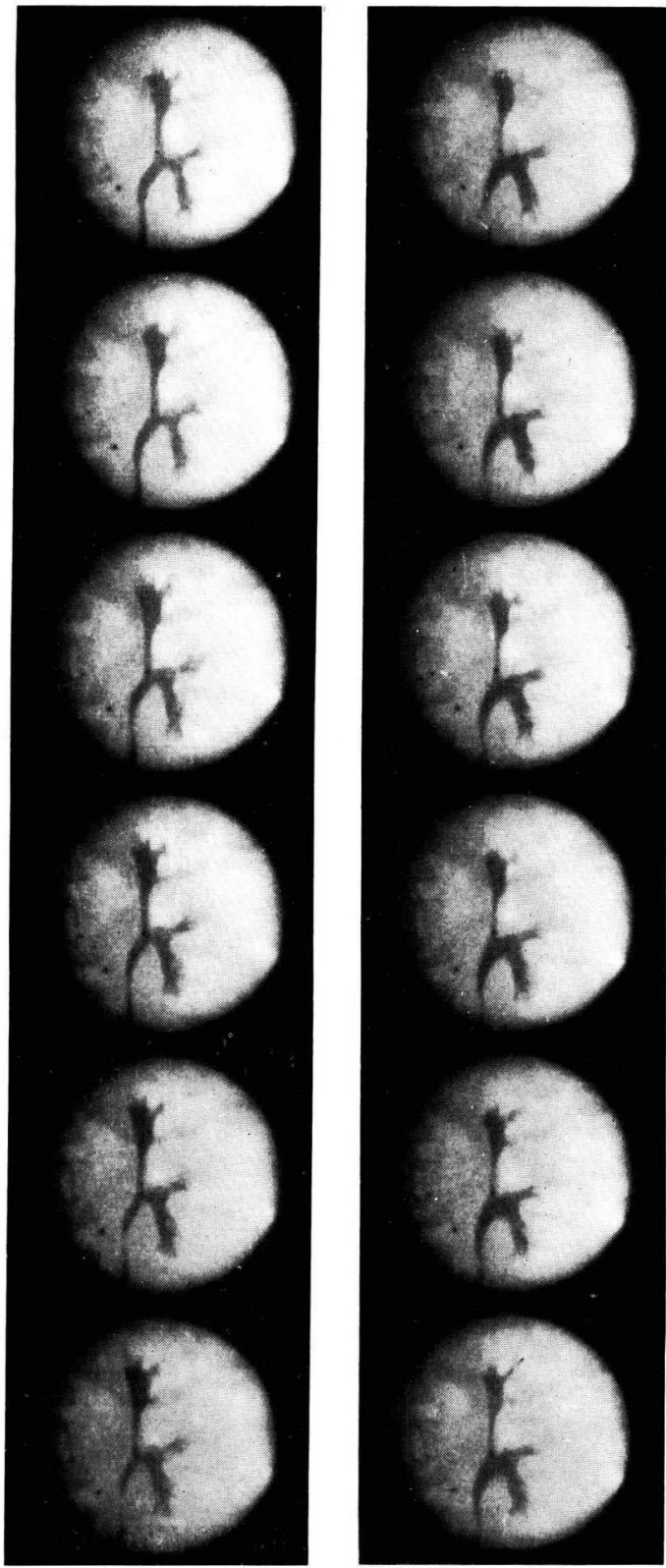

イ）上腎杯収縮から下腎杯の収縮期

口）下腎杯収縮極期と腎孟収縮開始，上腎杯逆流层張

八）腎孟收縮極期と腎孟尿管移行部収縮極期

））腎孟, 上部尿管弛緩期, 上腎杯は逆流後の縮小像 
休休止期以移行している。

婜杯，腎孟，腎孟求管移行部の連動の関係

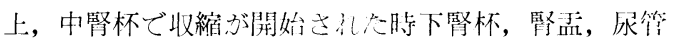

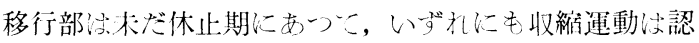

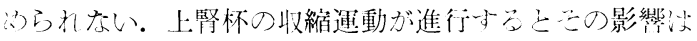

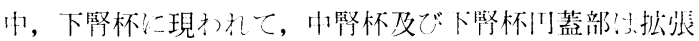

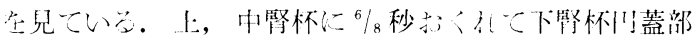

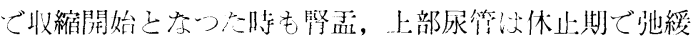

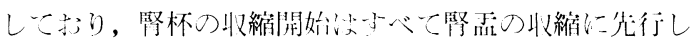
$\therefore$.

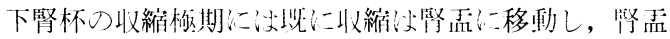

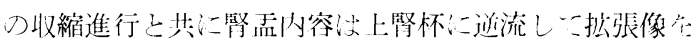

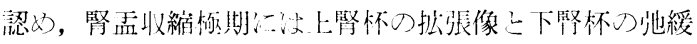
像及び腎孟尿管移行部の倣期上一致しん.

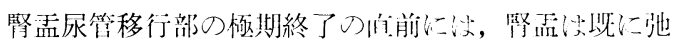

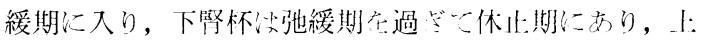

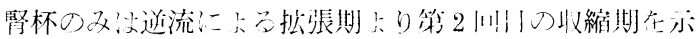
している.

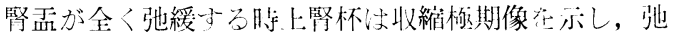
緩した下腎杯口蓋部に近流して該部に抬張像在䓯起して

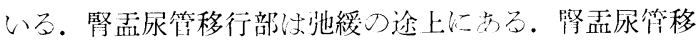

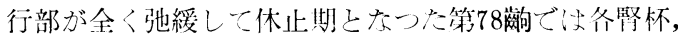
腎孟も既心休止期上なっている。

立位的抬け父遇動

被検者安战位とし，70\%ウロコリン $3.8 \mathrm{cc}$ 在通行性に

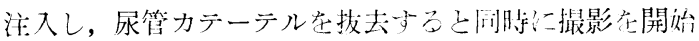
し，その計測任は第13図の尗である。

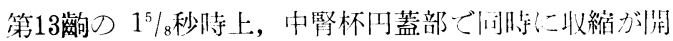
始され，下腎杯円蓋部でせ上，中腎杯に-1/8秒進れて收維 が開始されしている。蓋部の收維はいずれも督孟心向つ

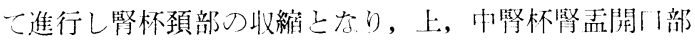

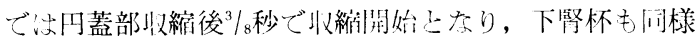

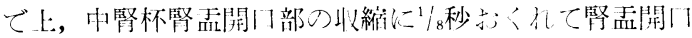

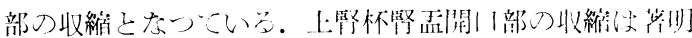
ではない。

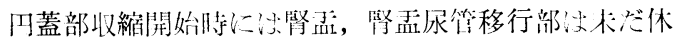
止期にあつて弛緩状態を示して扔り，篮盂尿管移行部以

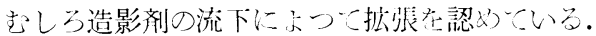

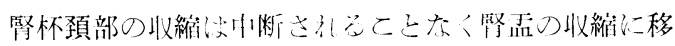

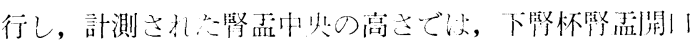

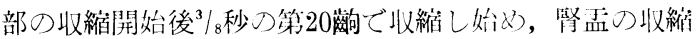

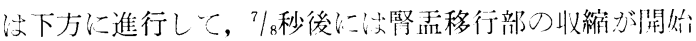
されている。

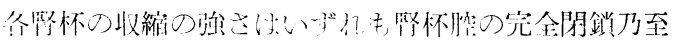

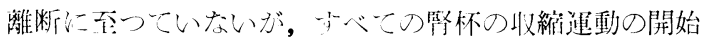

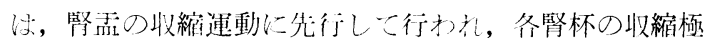

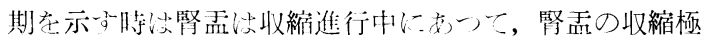

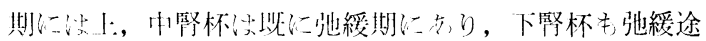

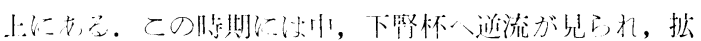

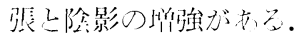

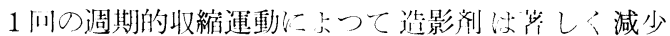
し，10秒後に以上，中篎杯门蓋部心造影剂の残留は認め

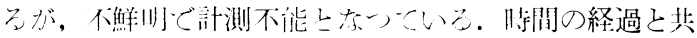

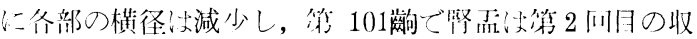

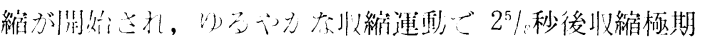

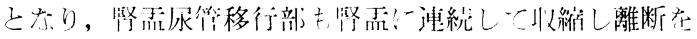
恧妙心。

遇動洞地

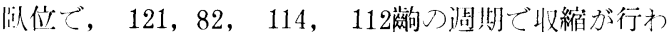

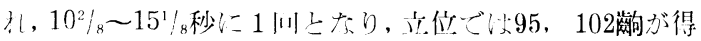

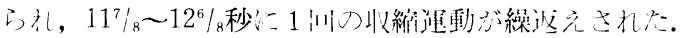
呼吸連動上の関係

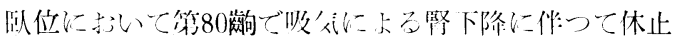

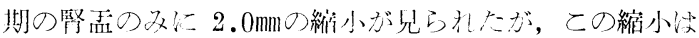

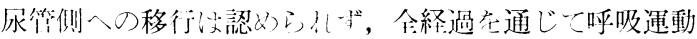

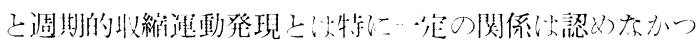
大.

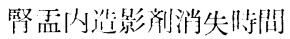

尿篗カテーテル报去後, 阶位で 4 分09秒，立位で 1 分

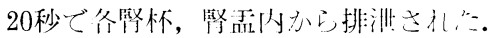

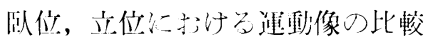

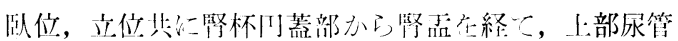

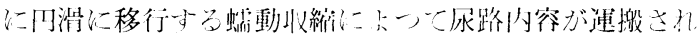

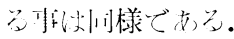

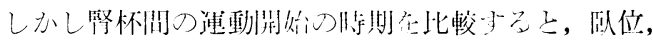

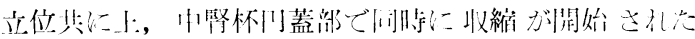

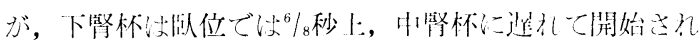

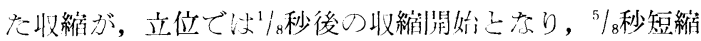

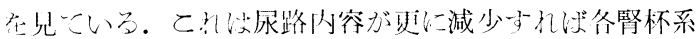

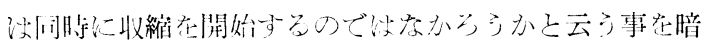

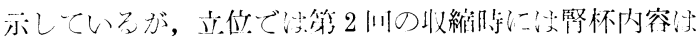

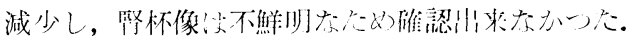

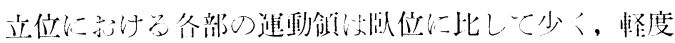

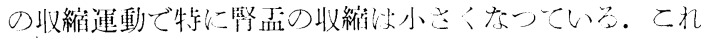

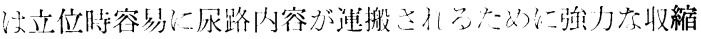

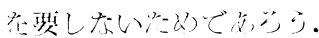


第15図 症例 3 , 立位

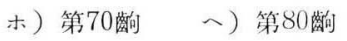

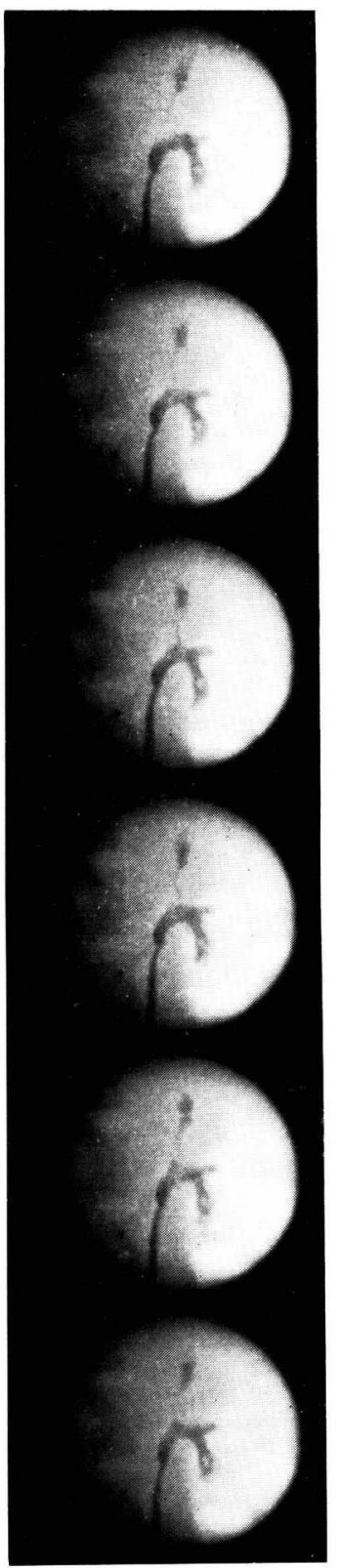

籍16成症例 4, 文位
E ）第 15 䔄
F ) 第32㩚
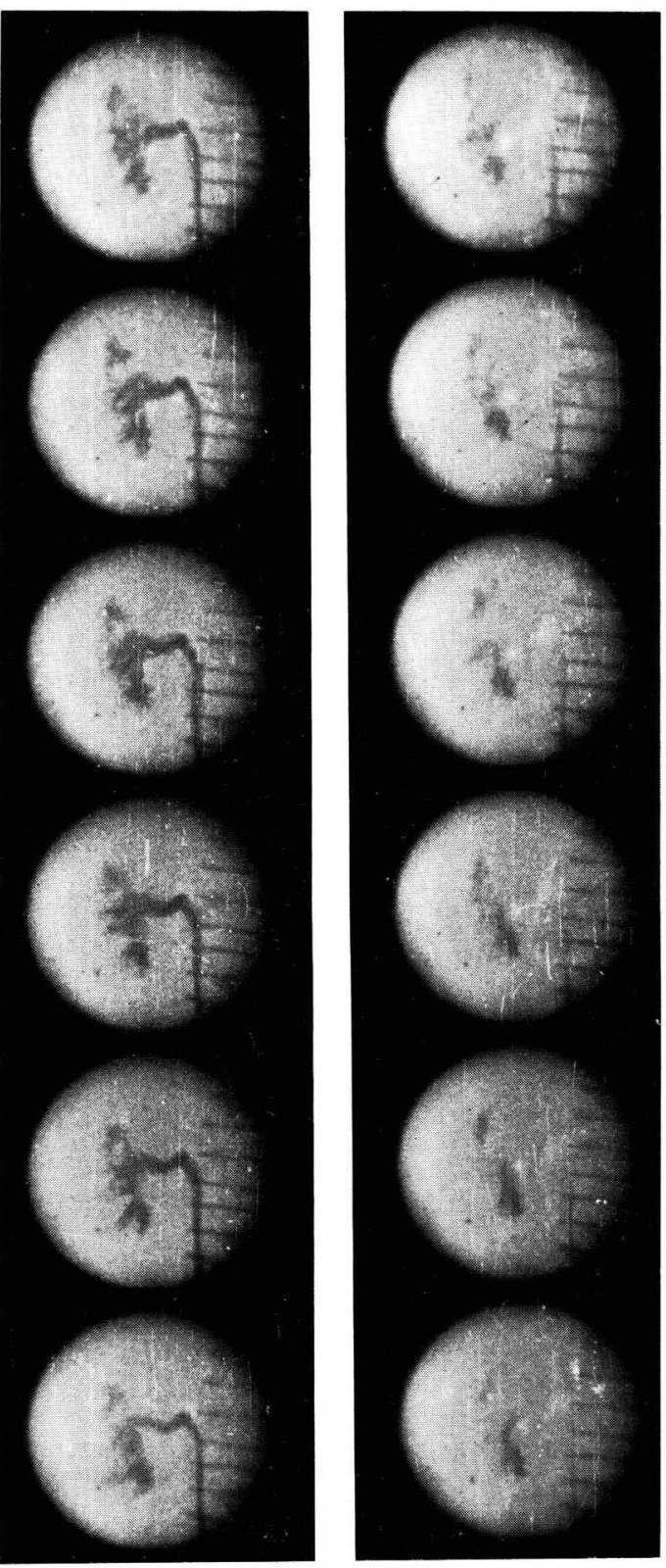

ホ），一）文位䊝の著明な造影郕排出圭示寸。

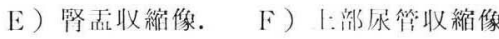


第 17 図
A ）第 40 萄句
B ）第50萄句
C ）第60萄
D ）第70嘆
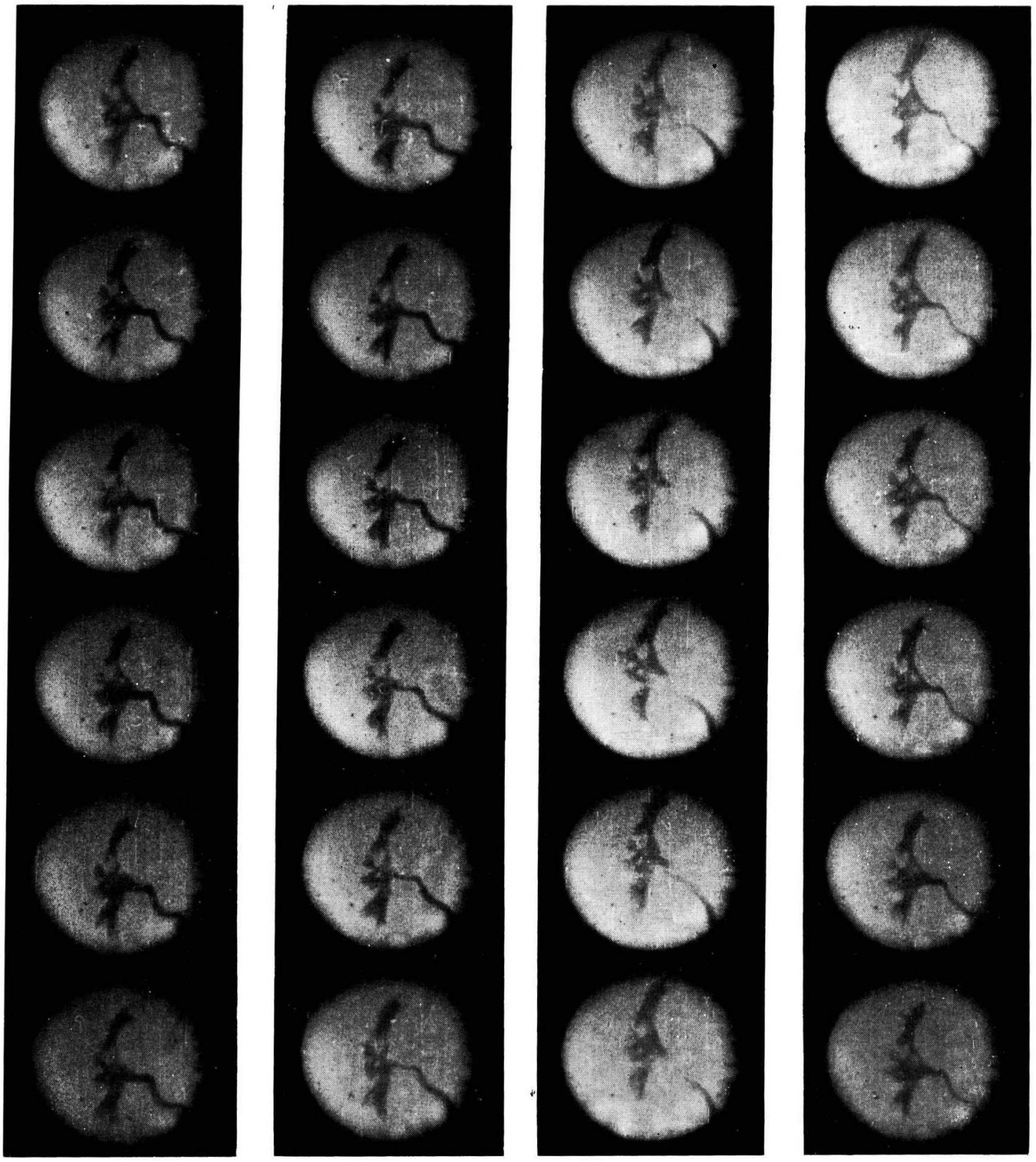

A）上腎杯収縮像，下腎杯逆流扗張像

B ）腎孟収縮像

C）腎孟漏斗部より上部尿管の収縮像，腎孟は腎杯側より弛綏を示す.

D ）上部尿管弛緩像 
第18図 計測值, 症例 4 , 臥位
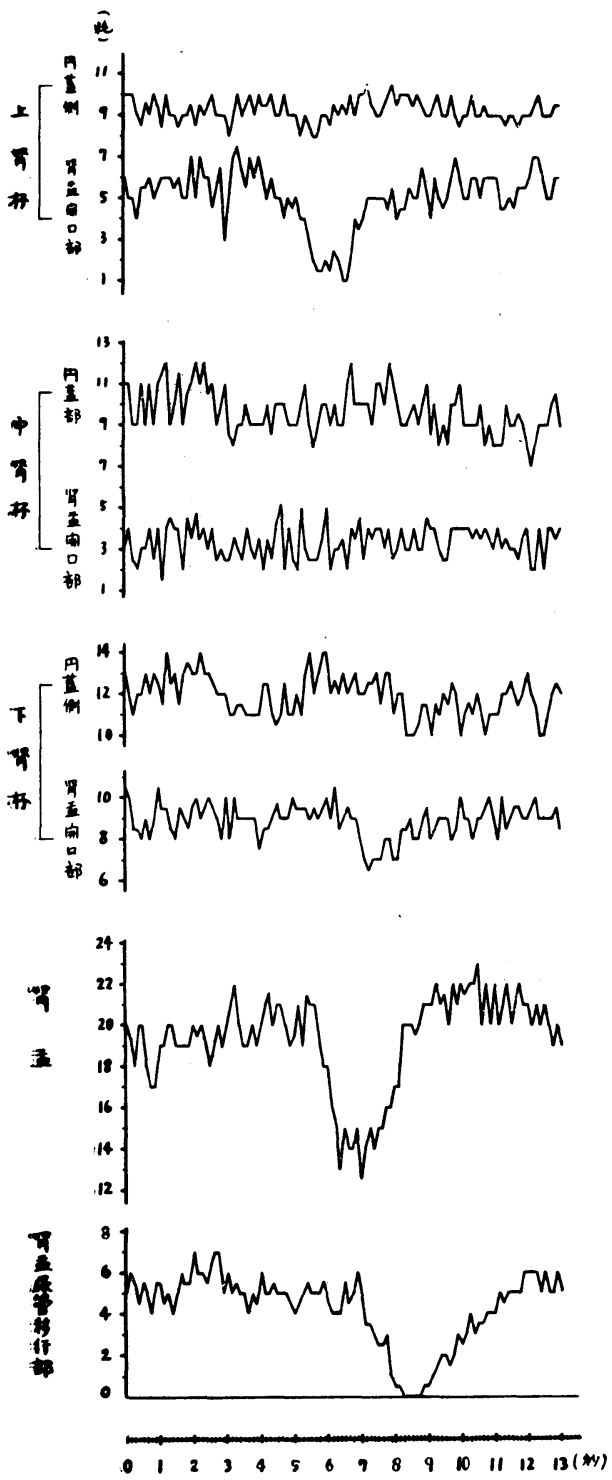

また腎孟収縮極期には立位でも, 中腎杯下腎杯円蓋側 《逆流現象を認めたが，上腎杯へ柱逆流なく，卧位にお いて逆流によつて収縮一拡張一収縮運動を行つた上腎杯 性收縮弛緩運動のみで，しかも腎盂開口部の運動は極め て軽微となつている. 中腎杯は逆に臥位では収縮弛緩運 動が明瞭でなかつたが, 立位をとると週期的収縮が円蓋 部より腎孟開口部へ向う蠕動運動として認められたの て, 腎杯運動が腎杯腎孟内容の変化に応じて変化する事 が判明した。
第19図 計測値, 症例 4, 立位
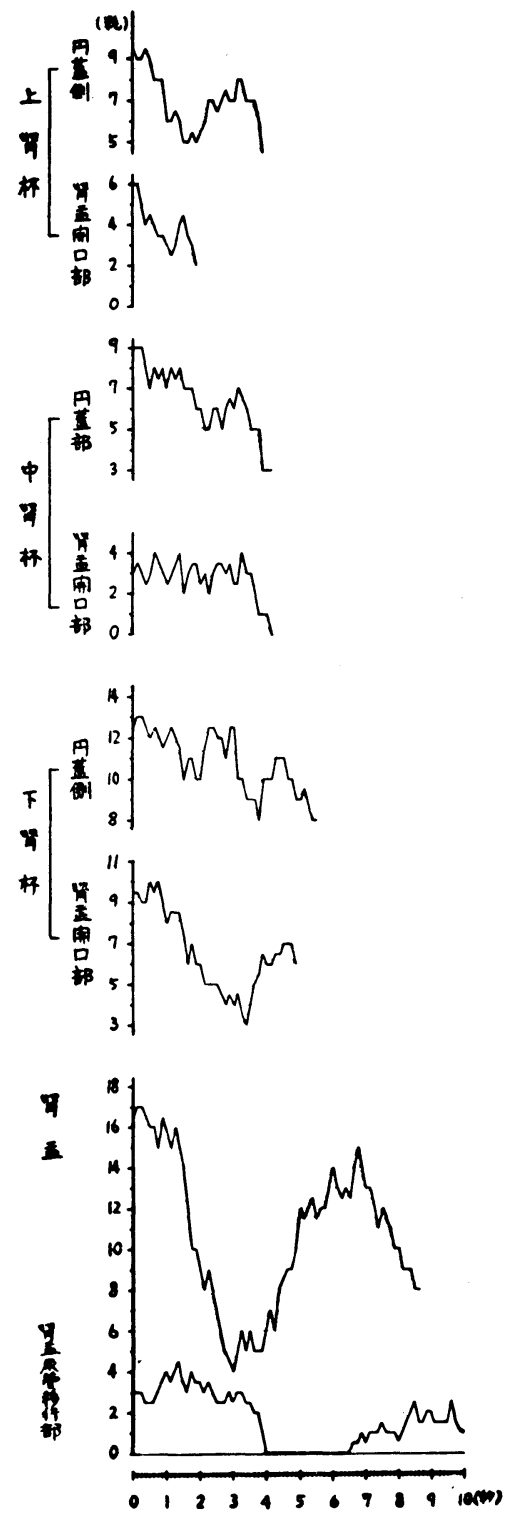

上腎杯収縮開始から腎盖尿管移行部の收縮に至る時間 は, 卧位で $3^{7} / 8$ 秒, 立位で $2^{6} / 8$ 秒を要し, この症例では 立位時早く伝達されている。

症例 4.45 才, 男子, 右腎

仰臥位, 70\%ウロコリン 3.0 ccを逆行性に注入した。 尿管カテーテルを抜去して30秒後より撮影されたフィル ムで第 112絾より13秒間計測し，レ線胦画像を第17図と 
第1表 腎杯横径の計測值 症例 $1 \mathrm{~S}=$ 収縮期,

\begin{tabular}{|c|c|c|c|c|}
\hline 齙数 & \multicolumn{2}{|c|}{ 円蓋部 } & \multicolumn{2}{|c|}{ 孟堅開口部 } \\
\hline$i / 8$ & $\mathrm{~S}$ & 8.0 & 4.0 & $:$ \\
\hline $2 / 8$ & & 6.5 & 3.5 & \multirow{5}{*}{$\mathrm{S}$} \\
\hline $3 / 8$ & \multirow{4}{*}{$\mathrm{D}$} & 7.5 & 3.0 & \\
\hline $4 / 8$ & & 8.0 & 3.5 & \\
\hline $5 / 8$ & & 8.0 & 3.0 & \\
\hline $6 / 8$ & & 8.0 & 3.0 & \\
\hline $7 / 8$ & \multirow{4}{*}{$\mathrm{S}$} & 7.5 & 4.0 & \multirow{3}{*}{$\mathrm{D}$} \\
\hline $8 / 8$ & & 7.5 & 4.0 & \\
\hline $9 / 8$ & & 7.5 & 4.0 & \\
\hline $10 / 8$ & & 6.5 & 3.0 & $\mathrm{~S}$ \\
\hline $11 / 8$ & \multirow{3}{*}{ D } & 8.0 & 3.5 & \multirow{3}{*}{$\mathrm{D}$} \\
\hline $12 / 8$ & & 8.0 & 4.0 & \\
\hline $13 / 8$ & & 8.0 & 4.0 & \\
\hline $14 / 8$ & $\mathrm{~S}$ & 6.0 & 3.0 & $\mathrm{~S}$ \\
\hline $15 / 8$ & \multirow{3}{*}{$\mathrm{D}$} & 7.0 & 2.0 & \\
\hline $16 / 8$ & & 7.5 & 3.0 & \multirow{4}{*}{$\mathrm{D}$} \\
\hline $17 / 8$ & & 7.5 & 3.0 & \\
\hline $18 / 8$ & \multirow{2}{*}{$\mathrm{S}$} & 7.0 & 3.0 & \\
\hline $19 / 8$ & & 6.5 & 4.0 & \\
\hline $20 / 8$ & \multirow{5}{*}{$\mathrm{D}$} & 7.0 & 3.0 & \multirow{2}{*}{$\mathrm{S}$} \\
\hline $21 / 8$ & & 8.0 & 2.5 & \\
\hline $22 / 8$ & & 7.5 & 3.0 & \multirow{4}{*}{ D } \\
\hline $23 / 8$ & & 7.5 & 3.5 & \\
\hline $24 / 8$ & & 8.0 & 3.5 & \\
\hline $25 / 8$ & $\mathrm{~S}$ & 7.0 & 3.5 & \\
\hline
\end{tabular}

第20図 䝳杯計測値

症例 1. 細線 $=$ 収縮期, 太線 $=$ 弛緩期

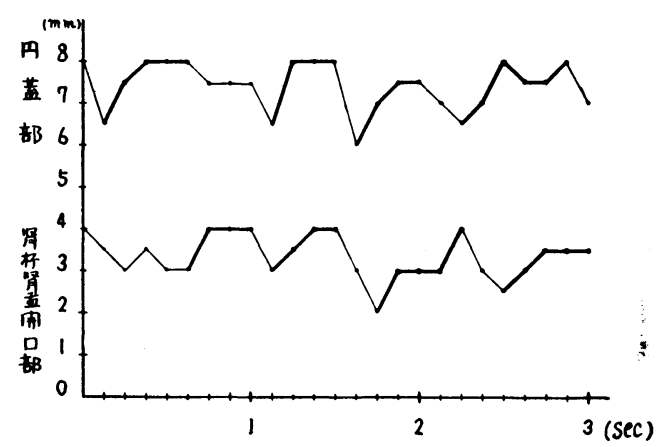

し, 計測值を第18図に示した。この症例では腎酉漏斗部 は水平位にあるため, 第 4 図 $\mathrm{d}^{\prime}$ の垂直断で計測した。

腎杯の運動

休止期の第22緌で上，中，下腎杯円蓋部で同時に収縮
第 2 表 腎杯横径の計測值 症例 $2 \mathrm{~S}=$ 収縮期, $\mathrm{D}=$ 弛緩期

\begin{tabular}{|c|c|c|c|c|}
\hline 数数 & \multicolumn{2}{|c|}{ 円蓋部 } & \multicolumn{2}{|c|}{ 腎孟開口部 } \\
\hline $1 / 8$ & \multirow{4}{*}{ D } & 10.0 & 3.0 & \multirow{4}{*}{$\mathrm{S}$} \\
\hline $2 / 8$ & & 10.0 & 2.5 & \\
\hline $3 / 8$ & & 10.0 & 2.0 & \\
\hline $4 / 8$ & & 11.0 & 2.0 & \\
\hline $5 / 8$ & \multirow{5}{*}{ S } & 10.0 & 3.0 & $\mathrm{D}$ \\
\hline $6 / 8$ & & 10.0 & 2.0 & \multirow{3}{*}{$\mathrm{S}$} \\
\hline $7 / 8$ & & 10.0 & 2.0 & \\
\hline $8 / 8$ & & 10.0 & 2.0 & \\
\hline $9 / 8$ & & 9.0 & 2.5 & \multirow{4}{*}{ D } \\
\hline $10 / 8$ & \multirow{4}{*}{$\mathrm{D}$} & 110 & 4.0 & \\
\hline $11 / 8$ & & 110 & 4.0 & \\
\hline $12 / 8$ & & 120 & 4.0 & \\
\hline $13 / 8$ & & 120 & 3.5 & \multirow{5}{*}{$\mathrm{S}$} \\
\hline $14 / 8$ & \multirow{4}{*}{$\mathrm{S}$} & 10.0 & 2.0 & \\
\hline $15 / 8$ & & 10.0 & 2.0 & \\
\hline $16 / 8$ & & 9.0 & 2.0 & \\
\hline $17 / 8$ & & 9.0 & 2.0 & \\
\hline $18 / 8$ & \multirow{2}{*}{ D } & 10.0 & 3.5 & $\mathrm{D}$ \\
\hline $19 / 8$ & & 12.0 & 3.0 & \multirow{4}{*}{$\mathrm{S}$} \\
\hline $20 / 8$ & \multirow{3}{*}{ S } & 10.0 & 3.0 & \\
\hline $21 / 8$ & & 9.0 & 2.5 & \\
\hline $22 / 8$ & & 8.0 & 2.0 & \\
\hline $23 / 8$ & $\mathrm{D}$ & 10.0 & 3.0 & $\mathrm{D}$ \\
\hline $24 / 8$ & \multirow{2}{*}{$\mathrm{S}$} & 9.0 & 2.5 & \multirow{2}{*}{$\mathrm{S}$} \\
\hline $25 / 8$ & & 9.0 & 2.5 & \\
\hline
\end{tabular}

第21図 腎杯計測值

症例 2. 細線 $=$ 収縮期, 太線=弛緩期
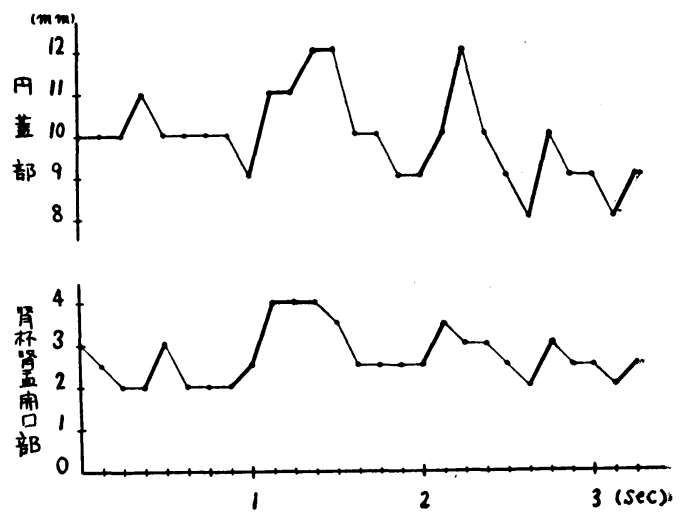

が開始された。 上腎杯 $3 / 8$ 秒, 中腎杯 $4 / 8$ 秒, 下腎杯 $16 / 8$ 秒: 収縮が持続し，この間に上，下腎杯では腎孟に向つて進 


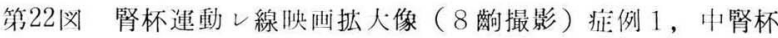
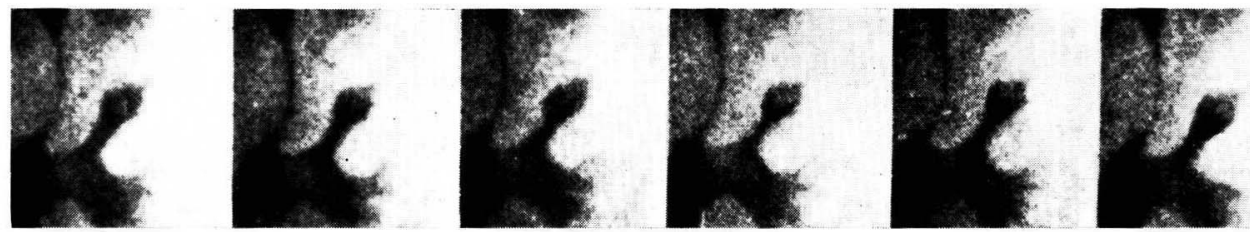

第23図腎杯運動レ線映画拡大像模型図，症例 1 ，中腎杯
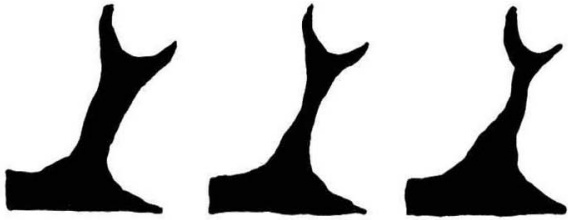

行し, $2 / 8$ 秒後上等杯㹂孟開口部， $5 / 8$ 秒後下婜杯開口部の

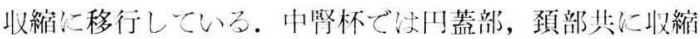

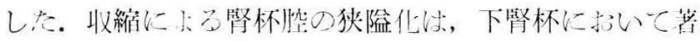
叮で上杯算円蓋侧冷特に少い。

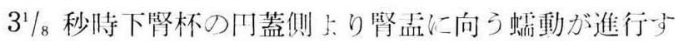

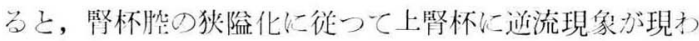

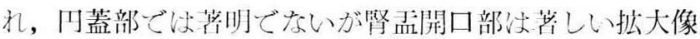

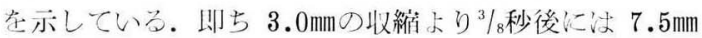
の掂張上なつている。逆流に上つて搪張した上㹂杯な，

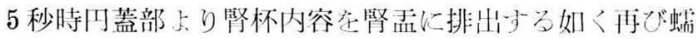
動的治く收縮運動を始めているが，㹂孟開口部でも閉 叙離断怘でには至つていない。

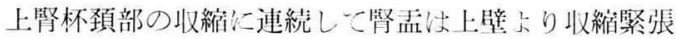

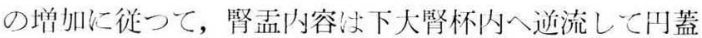
部，䅡部共汇搪張している（第17図A）。乙の近流沙腎 責の縮小と共に著明になり，筒盂収縮極期を過ざて驰緩

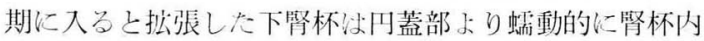

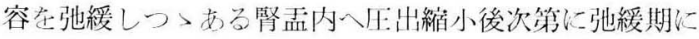
移行している。通流㹥下腎杯のみならず中腎杯にも認め られ，乙れに拮抗主る如く急激な収縮弛緩運動在繰遮え している.

慜酉の運動及び警孟尿管移行部の運動

$51 / 8$ 秒時上腎杯䅡部より中断するととなく連続して上 壁の収縮に移行し， $55 / 8$ 秒時纪决下腎杯側上り腎孟下壁

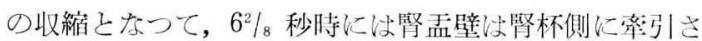
れて 7 秒時には, 求心性の収縮となり極期在示している (第17図B）。筒孟㓐の縮小に続き漏斗部も蠕動的に収縮 が移行している（第17図C）.

収縮極期学過ぎる上上腎杯側から弛緩し始め, 下腎杯
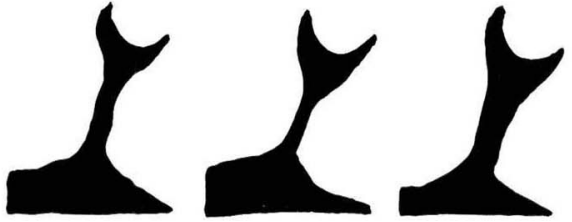

证道流に上る拙張から縮小在開始した後弛緩するため下 壁の池緩汶上壁に招くれて弛緩している。腎孟の上，下 壁池緩上共に尿管侧 一延長し，腎孟漏斗殏形成しつ >，更に収縮離断された腎冏尿管移行部も粲盂に連続し て上方分ら驰緩し，9秒時には腎杯，腎盂，上部尿管は 全く連続し、休止期乞なつている（第17図 C, D).

腎孟尿管移行部も蝡動収縮運動の通過飞小つて離断气 れ，独立した収繀像は認められていない。

とつで慜杯，腎孟，腎孟尿管移行部の関係至見ると， 週期的收縮運動山各腎杯系の円蓋部で 同㭙飞開始され た. 開始時灿腎孟，上部尿管㑊休止期にあって全く弛綏 している.

下腎杯の収縮進行上共以上腎杯法逆流红上り脑張像学 示し，上，下腎杯は逆の運動像を示している。

腎孟の収縮期认は先行した上筒杯の収縮期像上道流河 上る下腎杯の拡張像が見られ，腎孟漏斗部は収縮進行中 で女るが，尿管移行部は未だ造影剂で満されている（第 17図 B).

腎孟の弛緩期では，腎孟尿管移行部は蠕動的に収縮期

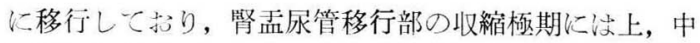
腎杯计坏に弛綏しており，下腎杯慜孟開口部及び腎孟は 弛綏途上にあつて，下腎杯円蓋部の及収縮像寺示した。 腎孟尿管移行部の弛緩期には，各腎杯系，腎孟は休止期 に移行し，いずれにも収縮は認めていない。

立位に扔ける運動

被検者を古位とし，70\%ウロコリン $4.6 \mathrm{cc}$ を逆行性に 注入すると上腎杯志で満され，尿管カテーテルの拢去々 同時你影した。第16図はレ線胦画像で，第19図はこの 計測值を示したものである.

尿管カテーテル抜去後から筒孟内の造影剂は弛緩して 
いる尿管内一盛に流下し，腎杯像活次第に縮小した。

$1 / 2$ 秒後, 上, 中, 下腎杯の円蓋側より同時に収縮が開 始された。収縮に上る腎杯の狭险化法腎盂へ向つて進行 し, 上腎杯 ${ }^{2} / 8$ 秒後, 下腎杯 ${ }^{3} / 8$ 秒後に腎孟開口部の収縮と なつている，中腎杯の腎孟開口部では著明な収縮弛綏老 絽返えすのみで持続的の収縮は認められない，腎杯円蓋 部の収縮開始時は，腎孟，尿管移行部は未だ休止期にあ つて全く弛綏して抢り，上部尿管は円蓋部収縮進行に伴 つて急に横径を增加し，しかも陰影は濃くなつているの で腎杯の腎孟内排出によつても腎孟内容の尿管への排出 が盛んに行われている.

腎杯頚部の収縮隹腎孟の収縮に移行し， $1^{3} / 8$ 秒時腎孟 上，下壁の順序で縮小した。 2 秒時腎孟收縮によつて 上，下腎杯円蓋側へ逆流し，陰影注增加している（第 目 a).

腎孟收縮極期の 3 秒時には腎孟漏斗部は収縮が始めら れているが，腎孟尿管移行部は多少緊張し始めているけ れぞも未だ造影剤で満されている。

腎孟の收縮極期を過ぎると上腎杯側から弛緩し，下筒 杯腎孟開口部のみ腎孟弛緩初期态で収縮を持続し，その 後弛緩して腎孟下壁の弛緩へと移行した。腎孟の弛緩が 進行するに従つて上，下腎杯の内容怯急に減少し， $3^{6} / 8$

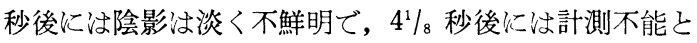
なつているが少量つ造影剂は未だ残留している.

下方尿管側へ移行した腎孟の収縮運動恃，腎孟が腎杯 側上り弛緩しつ>ある $3^{5} / 8$ 秒時に腎孟尿管移行部の収縮 となり，4 秒時收縮極期となり $2^{4} / 8$ 秒間離断された（第 16図 b).との離断した収縮梳，該部で離断した等〉上部 尿管に移行して蠕動的に下降し，尿管像怯消失して撮影 空外に出ている. $65 / 8$ 秒時腎孟漏斗部の弛緩に連続して 尿管移行部も弛緩し, 蠕動的に尿管上部より陰影を現わ している.

腎孟尿管移行部の収縮極期には, 腎孟 纴弛緩期にあ り, 各腎杯系は弛緩期ょり休止期の像となつている.

\section{運動週期}

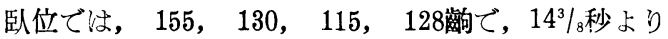
$19^{3} / 8$ 秒の週期が認められ，立位では 55,52 絧で $6^{4} / 8 \sim 6^{7} / 8$ 秒の周期が見られ, 立位に㧈いて頻数上なつている.

腎孟内造影剂消失時間

臥位, 8 分10秒, 立位, 3 分 21 秒で腎杯, 腎盘より排 泄された。

呼吸運動との関係

呼吸運動により腎が約 1 腰椎幅の上下移動を半つた外
には影響礼認められず，週期的收縮の発現と岋一定の関 係老見なかつた。

臥位，立位における運動像の比較

臥位，立位共に週期的収縮運動は各腎杯系で同時に開 始され, 蠕動的飞腎孟, 上部永管へ中断方る事なく移行 するのが観察された．しかしこの間にあって，卧位では 下腎杯の収縮に上る上腎杯への逆流と，上腎杯々腎孟の 収縮による下腎杯への逆流搪張像が見られたが，立位で

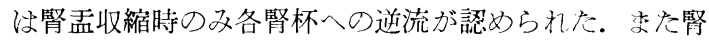
杯腎盂逆流現象のため, 収縮-一拡張一収縮の 2 相性の収

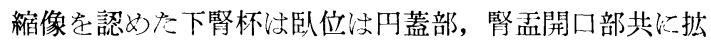
張像を認めたが，立位では円蓋部のみで腎孟開口部に隹 認められなかつた。婜杯間の逆流現象已腎寻内造影剂の 消失時間から臥位の方が明らかに貯溜しやすい事を示し ている. 円蓋部上り腎盂尿管移行部へ收縮が到達する時 間は, 臥位で $5^{4} / 8$ 秒, 立位では $3^{4} / 8$ 秒となつている。

\section{V 総括及び考按}

4 例の逆行性腎盂レ線映画像を観察すると腎杯より上 部尿管に至る尿路壁のいずれにも強い収縮運動が認めら れない或る期間の休止期の後に，腎杯円蓋部で開始され て腎㙉に向い，更に腎孟から腎孟尿管移行部学経て上部 尿管へ中断する事なく連続して移行する週期的蠕動収縮 が認められた。

この休止期にあつて尿路注驰緩状態と云つても全く拡 張したま〉運動を停止しているものではなく，尿路内容 に応じた緊張度を保つて, 各尿路壁は微練な波動様の緊 張変化を示し，乙の緊張の增減は極めて急速に行われ， 特に腎杯壁で著明に観察された。

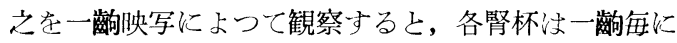
異つた運動像を示しており, との緊張の増加は, 或る場 合には明らか腎杯胿を狭めて腎杯内容を腎盂に向つて 駆出する収縮運動と看做される運動像 が認められたの で, 之を後に述べる腎盖に移行する腎杯の週期的収縮運 動の外汇腎杯固有の運動乞して観察した.

\section{〔1〕腎杯の運動}

a）腎杯固有の運動

対象とした腎杯は，独立して腎盂に開口する小腎杯で ある第 1 例及び第 2 例の中腎杯で, 円蓋部乳頭尖端の高 さと，腎杯腎孟開口部の横断径を休止期注扮ける 3 秒間 の拡大像について, 一顽毎に計測し, 腎杯壁の緊張增減 を時間的経過と共に調べた.

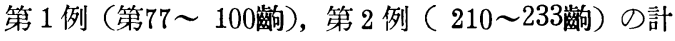
測值を夫々第 1,2 表とし, 計測值で $1.0 \mathrm{~mm}$ 以上の減少 
を収縮期 (S ）として細線に，1.0mm以上の増加を弛緩 期 (D) として太線に表わして, 夫々第20四，21図とし た.

第 1 例の中腎杯では，円蓋部で $1 / 8 \sim 4 / 8$ 秒の収縮期と， $1 / 8$ 〜 18 秒の弛緩期があり, 腎杯腎孟開口部では, $1 / 8 \sim 5 / 8$ 秒の収縮期已弛緩期が認められた。 また収縮，弛緩によ る横径の変化值快, 円蓋部収縮期 $1.0 \sim 2.0 \mathrm{~mm}$, 弛緩期 $1.5 \mathrm{~mm}$ ，腎杯腎孟開口部収縮期及び弛緩期共に 1.0 $2.0 \mathrm{~mm}$ 增娍を示した。第 2 例では，円蓋部で $3 / 8 \sim 4 / 8$ 秒 の収縮期と $1 / 8 \sim 4 / 8$ 秒の弛緩期が連続し，腎杯腎孟開口部 $て^{3} / 8 \sim 5 / 8$ 秒の收縮期と $1 / 8$ 秒〜 $4 / 8$ 秒の弛緩期があり, 円蓋 部で 2.0〜 4.0mmの収縮値と $2.0 \sim 3.0 \mathrm{~mm}$ の弛緩值, 腎 䀃開口部では 1.0〜 1.5mmの収縮值と，1.0〜 $2.0 \mathrm{~mm} の$ 弛緩値の変化が計測され，収縮弛緩の強さも持続時間も 一定しない腎杯壁の収縮 と弛緩運動が連続的汇急速に行 われている。

円蓋部之腎杯腎孟開口部に扮ける両者の運動時相を比 較する上，第 1 例では共に収縮期及び弛緩期を示してい る場合と，円蓋部の収縮期と腎盂開口部の弛緩期或快前 者と後者が全く逆の運動相を示す場合があつて同時又は 交互に運動するょうに見える。

しかし, 計測値の変化は円蓋部と腎孟開口部間の運動 の連続性を表わしているものではないので，両者が全く

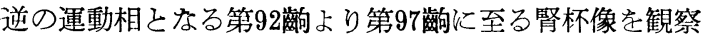
儿て，その拡大像と模写図を夫々第22及び 23 目とする と, 両者共に弛緩期から円蓋部の収縮開始時は腎杯腎孟 '開口部は尚弛緩の途上にあり，第94䍃で円蓋部収縮極期 には収縮緊張柱腎杯䅡部の略々中央まで進行しているが 腎孟開口部は弛緩極期である。円蓋部で収縮が終了して 弛緩期に移行する第95顽では腎孟開口部に収縮 が 移行

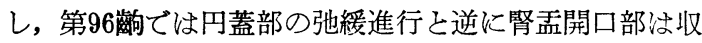
縮極期を示し，第97磷では腎盐開口部は円蓋部に抢くれ て共に弛緩期を示している。 との様に円蓋部より腎杯腎 盖開口部に向了蠕動収縮弛緩運動が認められた。

第 2 例に执いて山 3 回の両者共に収縮弛緩する律動的

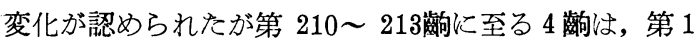
例と同様相反する運動時相のずれがあり，蠕動収樎を混 入している。腎乳頭部先端:より 腎孟開口部までの長さ は, 第 1 例 $21 \mathrm{~mm}$ に対し, 第 2 例は $11.5 \mathrm{~mm} て ゙$ 短く, 収縮進 行は迅速であるため第 2 例では多くの運動像が同時収縮 弛緩像となつているものと考えられるので，腎杯運動に 関しては毎秒 8 鉂撮影より更に高速撮影の必要を暗示し ているょうである。
以上の所見から腎跙の休止期にあつて腎杯の円蓋部か ら腎杯督孟開口部に向う蠕動収縮運動が頻回に繰返えさ

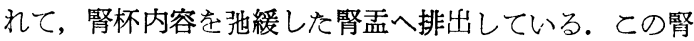

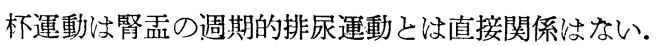

Catel u. Garsche ${ }^{25}$ ) は，每秒16嵫撮影炕上り得られ た腎杯円蓋部には，“ flimmernde” oder “ pendelnde”之形容される頻発する運動があり， 円蓋と乳頭先 端の高さでその横径を計測し，両者共に収縮弛緩する律 動的收縮弛緩運動が 43 絁中に 6 回行われた 症例老 報告 し，ての運動にょつて乳頭部集合管より腎杯への尿の排 出が助けられると述べている，その他腎杯固有の運動 は, 既に大原, 兼松によつて観察され, 夫々 4 回, 9回 の腎杯運動が腎責休止期に行われた症例を認めて招り, 著者も 3 秒間飞 3 乃至 4 回の腎杯蠕動運動を確認した通 り，いずれもレ線呐画によつて明らかにされたものであ る.

しかし円蓋部輪状筋が乳頭を括約すると云了能力恬, Narath の解剖学的所見功否定されており, 辻も同じ 見解である、筆者の腎杯像からもその収縮性不完全で円 蓋部を全く閉鎖して陰影を消失せしめる程強力な収縮て はなく, Catel 等のよう飞乳頭部の括約による尿排出へ の寄与は考えられない。腎杯固有の運動圢, 辻の腎杯輪 状筋運動説を支持出来了運動像で, Narath の腎杯運動 説とは異つた蠕動運動であり，その目的注腎杯内容の腎 孟への運搬にあると考えられる.

b) 腎杯の週期的収縮運動

腎㙉及び上部尿管の休止期に怯上述の腎杯内容を腎孟 へ排出する急速な堅杯壁の蠕動運動が絽返えされた後に 各腎杯系の円蓋部で開始され，腎杯䅡部から腎盂へ，更 に上部尿管に円滑に移行する強力な収縮蠕動運動が認め られ, この蠕動運動议週期的に行われた.

個々の腎杯について，蠕動収縮の開始を見ると，㹂杯 円蓋部で開始された収縮は，腎孟側へ向つて進行し， $1 / 8$ $\sim 1^{1} / 8$ 秒後に腎孟開口部の収縮に連続して抢り，乙の収 縮の進行状況は，第 1 例上腎杯(第 5,6 図), 第 2 例下 腎杯(第 8 図), 第 3 例下腎杯 (第14図) で見る如 $<$, 蠕 動収縮弛緩運動で，腎杯上り中断する事なく腎典の収縮 に連続している．運動像と計測に上る収縮弛緩期の時間 的推移を併わせ見れば，腎杯の週期的運動が蠕動形式で ある事も明らかである。しかし短小腎杯の中腎杯系で 法, 第 2,4 例の如く円蓋部々婜盂開口部は同時に収縮 期こして観察された腎杯もある.収縮進行が極めて早い ために，第 3 例上腎杯のように長大腎杯でも実際に映写 
して観察する時恃，円蓋部，頝部同時に収縮したように 見える場合もある。腎杯の週期的収樎運動扎いても，

8 锁以上の撮影速度が要求されるょうである.

レ線映画像の計測によつて知り得た腎杯の運動汢，円

蓋部, 腎盖開口部で

(1) 休止期 $\rightarrow$ 収縮期 $\rightarrow$ 弛緩期 $\rightarrow$ 休止期（第 1 例上腎 杯，中腎杯腎孟開口部，第 2 例上腎杯円蓋側，下腎杯腎 孟開口部, 第 3 例下腎杯腎孟開口部, 第 4 例立位下腎杯 腎盂開口部）の基本的収縮弛綏運動の他々

(2) 休止期 $\rightarrow$ 収縮期 $\rightarrow$ 拡張期 $\rightarrow$ 収縮期 $\rightarrow$ 弛緩期 $\rightarrow$ 休止 期（第 1 例中腎杯円蓋部，下腎杯腎盂開口部，第 3 例上 腎杯，第 4 例臥位上，下腎杯）

(3) 休止期 $\rightarrow$ 収縮期 $\rightarrow$ 払張期 $\rightarrow$ 縮小期 $\rightarrow$ 休止期（第 2 例下腎杯円蓋部)

(4) 休止期 $\rightarrow$ 拡張期 $\rightarrow$ 収縮期 $\rightarrow$ 拡張期 $\rightarrow$ 縮小期 $\rightarrow$ 休止 期（第 2 例上腎杯腎孟開口部，第 3 例下腎杯円蓋部）の 4 型の運動像が認められた。縮小期よしたの注，一時拻 張した腎杯腔が休止期以下の狭险化を示さずに漸次休止 期の緊張汇還つた場合である。

同一腎杯でも円蓋部，腎孟開口部共に同じ運動型をと る時（第 1 例, 上腎杯(1), 第 3 例, 上腎杯(2), 第 4 例, 下腎杯(2) と, 両者が異つた型をとる場命（第 2 例, 上 腎杯円蓋側(1) と腎孟開口部(4)，同下腎杯円蓋側(3)腎孟 開口部(1)，第 3 例，下腎杯円蓋側(4)之腎孟開口部(1)）が あり，同一腎に捛いても第 1 例，第 2 例，上，下腎杯系 のように腎杯により異つた運動型が認められて, 運動型 の発現と腎杯との組合せには一定の関係汹認められな い. 計測によつて多くの腎杯は，収縮弛綏の経過に拡張 期が嵌入されて甚だ複雑な運動像を呈する事が判明した が, この拡張期は腎杯の能動的な拡張ではなく, 腎杯胿 への逆流による受動的な拡張である事は拡張期に一致し て他の部で強力な収縮が計測されている事から充分推察 出来る. 即ち腎杯ょり移行して腎盂の収縮期になると腎 孟内容の一部が腎杯内に逆流して腎杯の搪張を惹起する ばかりでなく，腎杯間でも収縮運動の進行と共に他の腎 杯への影響は拡張となつて現われる関係法，第10及び第 12図で明らかである.

逆流現象を見ないで基本的な収縮弛緩運動のみを認め た腎杯について，その運動時間を計ると，収縮期と弛綏

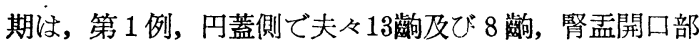

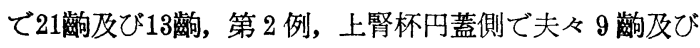

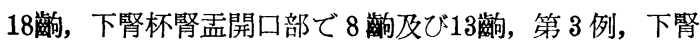

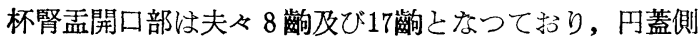

では $1 \frac{1}{8} \sim 1^{5} / 8$ 秒の收縮期 と $1 \sim 2^{2} / 8$ 秒間の弛緩期があ り, 督孟闒口部では $1 \sim 2^{5} / 8$ 秒の収縮期と, $1^{5} / 8 \sim 2^{1} / 8$ 秒 間の弛䌅期が認められ, 収縮又は弛緩に要する運動時間 洁一定の傾向は認力られない。

収縮開始後逆流現象を半つた腎杯では，第 4 例に例を とると，上腎杯腎孟開口部で $1 / 8$ 秒の収縮を示した後に $3 / 8$ : 秒間の急速な拡張があり, その後法 $3^{2} / 8$ 秒間徐々に収縮 して腎杯内容を排出すると共に開始時より強力な収縮を 行つて, $2^{1} \frac{8}{8}$ 秒の弛緩期を経て休止期に至つている. こ れに反して下粲杯では円蓋部 $1^{2} / 8$ 秒, 腎盘開口部で $/ 8$ 秒 の收縮の後に極期となり, その後に逆流による桩張があ つて開口部で $3 / 8$ 秒間の急激な収縮を示すのに対し, 円蓋 部では徐々に $24 / 8$ 秒間の収縮を示しているが, 一般的に 注開始時の収縮より逆流後の収縮の方が強力で収縮時間 も長い場合が多い。

円蓋部で収縮が開始されて蠕動的に腎杯腎盖開口部の 収縮弛綏を経過し, 全く休止期に至るまでの腎杯の全運 動時間を見ると，督杯頝部で全く収縮離断された第 1 例 上腎杯は， $4^{7} / 8$ 秒を要したのに対して逆流を見た他の大 腎杯では $54 / 8 \sim 8$ 秒を要し, 逆流による拡張期が加わつ て延長されることを示している。 また第 1 例の短小腎杯. である中腎杯でも $6^{5} / 8$ 秒の運動時間が計測され, 腎杯の 大小拘らず逆流現象化よつて腎杯の週期的収縮運動の 時間は延長するものと考えられる。

腎杯における収縮運動の強さは計測值の減少で示され ているょうに, 円蓋部で, 最小 $2.0 \mathrm{~mm}$ (第 4 例, 上腎 杯）～最大 $5.5 \mathrm{~mm}$ (第 2 例上腎杯) の収縮之, 腎孟開口. 部では収縮弛緩を明瞭に区別出来ない第 3 例の中腎杯吕 ら $6.5 \mathrm{~mm}$ の诚少を見た第 4 例上腎杯があり, 腎杯の大き さには関係していない。

いずれの腎杯も円蓋部では 1 回の収縮で腎杯腔を完全 に狭隘閉鎖する程の収縮は認められず, 各例とも数分後: の督孟内造影剂の減少に平行して腎杯内容も減少する が, 造影剂が腎孟内に存在している限り腎杯円蓋部にも。 恒に残留しているのが認められた。 また腎杯䅡部及び腎: 孟開口部の運動領の小なる第 1 例上腎杯は, $2.0 \mathrm{~mm}$ の収. 縮で笔全に離断されたが, 同一腎でも下腎杯腎孟開口部、 は計測上 $3.0 \mathrm{~mm}$ の収縮を行つているが, 造影剤が残存し ている範囲では, 終始収縮による閉鎖離断は認められ ず，第 4 例下腎杯に扢いても同様である．また腎杯，腎 孟内の造影剂の減少した時 第 1 例中腎杯 ( 2 分後), 第; 2 例下腎杯 ( 4 分後), 第 4 例上腎杯 ( 2 分後) の腎孟開 口部の完全閉鎖離断が見られたが，すべての腎杯に閉銷: 
能力が恒に存在するとは限らないようである.

被検者を立位とした時の腎杯の運動恃，臥位と同じく 円蓋部で開始されて腎㙉開口部へ移行する蠕動収縮が認 められた，立位時注入された造影剂证急速に腎孟上り尿 管へ流下し 1 乃至 2 回の週期的収縮運動によつて大量の 排出が行われ，陰影は减少するので上，中腎杯系は上方 加腎杯像消消失し，10秒以内に 計測不能となつてい る.上，中腎杯では収縮運動によつて排出されると云う より，造影剂の自然流下の方が著明である.

第 3 例，上，下腎杯と第 4 例，上腎杯及び下腎杯腎孟 開口部では，臥位に执いては腎孟腎杯逆流により収縮 $\rightarrow$ 应張 $\rightarrow$ 収縮 $\rightarrow$ 弛綏の運動が, 立位ではいずれも収縮 $\rightarrow$ 弛 緩の基本的収縮運動型に還えり，特に第 3 例の中腎杯 は, 臥位に执いては明膫に認められなかつた収縮運動が 立位時には円蓋部より腎孟に向う蠕動運動を現わしてい る. との様な症例では運動時間も短縮 している. しか し, 第 2 例の下腎杯は上記の 2 例とは逆に腎盂開口部て 立位時腎盂収縮に上る逆流が起つて, 第(1)型兮ら第(2型 に変化し, 運動時間も延長している.

体位の変化によつて腎杯連動の変化を来たす事は, 造 影剤の腎孟内分布の変化から逆流の有無に従つて生ずる ものである. また腎杯運動が或る腎杯で一定の運動型て 終始するものではない事を示している.

腎杯の運動以個々の腎杯の観察に加えて, 必ず他の腎 杯或は腎孟間の収縮 との関係を考慮しなければならな い.

c）腎杯間の収縮運動の関係

腎杯を上，中，下の 3 腎杯系に大別して，円蓋部収縮 開始時期を比較与ると, 第 1 例(臥位), 第 4 例（臥位, 立位)の 2 症例は， 3 腎杯系で同時に開始された。

第 2 , 第 3 例牲臥位で, 下腎杯円蓋部の収縮開始柱夫 々 $2^{3} / 8$ 秒, $6 / 8$ 秒上, 中腎杯に抬くれて発現した. 4 例と も上，中腎杯系は同時に收縮が開始されている.

下腎杯の収縮開始が遅れた第 3 例臥位について第 12 図 を見ると, 上, 中腎杯円蓋側での収縮が開始されると下 腎杯円蓋部の横径は增加し, 逆流による拡張を認めた 後, 収縮が開始されて抢り, 甚だ興味ある事は同一腎で 逆流現象の消失した立位時には, 臥位の $6 / 8$ 秒の遅延から $1 / 8$ 秒に短縮されて下腎杯の収縮発現となつている事であ る. それ故下腎杯収縮発現の遅延は逆流現象によると考 えられ，立位時の急速な腎孟内容の排出が行われる結 果, 腎杯より腎孟への抵抗減少に伴つて容易に収縮運動 が行われるものと考えられる，換言すれば，低利尿状態
下では各腎杯系の円蓋部で同時に収縮が開始し，腎盂へ 向つて進行すると思われる.

Narath ${ }^{99}$ は腎杯壁平滑筋の協調によつて行われる緩 徐な collecting phase と,急速な emptying phase の 2 つの運動像（第1図）を示したが，彼によれ腎杯 は円蓋部と腎孟開口部で恒に交互の収縮弛緩像を繰返え している事になる．著者の所芫は，腎杯円蓋部より腎孟 開口部に至る蠕動収緶運動で, 最も異なる所見は共に収 縮期又は弛䋸期の進行が見られる事と，全腎杯の運動時 間よりも注るかに長い休止期があつて円蓋部，腎孟開口 部共に弛綏状態を続け，収縮運動次週期的に行われる事 である. しかし休止期の弛緩状態と言つても緊張の増减 を示す事は前項で述べた。 また腎杯が腎孟尿管移行部と 協調して運動が見られると述べているが，てれは後に言 及する。

Johnson $^{64)}$ は括約筇で区切られた小分節が一定の䦨値 に達するまで括約筋は収縮していると述べているが，腎 杯䅡部の括約筋部は螦動波の通過によつて収縮運動を営 むけれども，休止期の間腎杯と腎盂の収縮離断せしめる 運動の持続は認められない。

腎杯の運動像から週期的収縮運動も辻 ${ }^{125)}$ の腎杯輪状 筋運動説が支持される.

著者の得た腎杯運動も小野（レ線キモグラフィー） ${ }^{105)}$ 三矢 ${ }^{911}$ 及び大原 ${ }^{107)}$ (レ線映画) 等の観察と同様の蠕動 運動も認めたが, すべて一致するものではない，即ち三 矢，大原の如く腎杯頚部から収縮が開始された症例はな い. しかし第 4 例上腎杯 (第18図) の円蓋部の収縮運動 は腎孟開口部のそれに比して極めて弱小であり, 計測法 によつて收縮を知り得たが，映写又はビュアーによる観 察では腎杯頝部にのみ収縮弛緩運動が存在するように見 える場合がある. 第 1 例, 上腎杯 (第 7 図) で円蓋側で 収縮開始後，腎孟開口部も共に収縮極期となつてから円 蓋側加弛緩し全く弛緩後に腎孟開口部の弛緩が始めら れているのは, 小野のキモグラフィーの所見と一致する が，第 2 例上，下腎杯 (第10図) のように同時に極期を 示すとは限らず，また第 3 例下腎杯（第12図）は共に収 縮極期の後殆んど同時に弛緩期に移行しているので，大 原の所見と一致した腎杯も認められたが，小野とは異つ た場合むある。

第 2 例, 上, 下腎杯 (第10図) の運動圷, 円蓋側と腎 孟開口部の運動時相が相反している所見が得られたのみ でな（第8図（3)）に示されたように，Narath の goblet 形成に似た弛緩像がある。これは円蓋部より腎孟 
開口部へ進行し，弛緩も円蓋部から始まる蠕動運動の一 過程である事は，映画像の連続印画から明らかである.

また goblet 形成訬腎孟腎杯逆流現象により受動的に形 成されたものであるＮNarath は腎杯の収縮完成末では 多くの場合 1 秒以内の事象であると述べているが，著者 の例では第 1 例の腎孟開口部は $2^{5} / 8$ 秒の収縮期があり, 腎杯全体から言元ばはるかに長い収縮を示す事は明らか である. 腎杯の休止期に行われる固有の運動は 1 秒以内 であるが週期的収縮運動には商用されない。

Narath の腎杯運動説は連続性に乏しいフィルムから 得られた知見と考えられる. 彼は満足すべき所見を得る に流每秒 4 枚の撮影が必要であると述べているが，著者 注毎秒 8 溦撮影恃最小限度と考える。

各腎杯間の収縮運動は，Hennig (1937) ${ }^{53)}$, Narath (1940） ${ }^{99)}$ は総べての腎杯が同時に運動するととはない と述べて抢り, 大原 ${ }^{1077}$ は収縮運動が全腎杯に認められる 時上，一部の腎杯にのみ見られる場合があり，各腎杯の 運動開始と終了は或る範囲で異なり一斎に開始され，一 斉行終了するものではないが，各腎杯間には一定の運動 の序列は認めないと述べ，兼松も各腎杯は別々に運動す ると云う．之に対し Catel (1957) ${ }^{25)}$ 虫上，中，下腎杯 は同時に同じ運動態度を示す事もあり，上，中腎杯と下 腎杯は全く逆の機能状態を示す事学観察しており，Bodner 等 ${ }^{15)}$ は, 各腎杯系が同時に収縮する場合と, 右及 び左迴りの順序で行われる場合があるようだと記載して いる.

著者は計測に上つて 4 例中 2 例恰上，中，下腎杯系円 蓋部で同時に収縮開始があり，2 例は上，中腎杯系は同 時に，下腎杯の夕遅れて発現した。しかし Bodner の ように下腎杯より開始する症例は認められなかつた。

Oeconomos (1937) ${ }^{103}$ は, 尿の排出は一種の反射て むつて，反射の刺战は上部尿路の尿による機械的並びに 化学的刺㦸であり，Th 6 ～11迄の脊髄後根から脊䯣の 反射中枢に伝わり，と>から運動性神経が腎平滑筋に達 しているものとしているが, Lapides(1948) ${ }^{78)}$, Johnson
$(1952)^{64)}$ は上部尿路運動の起因には神経源性を否定し ている. しかしこ>て 4 例中 2 例は 3 腎杯同時に収縮が 開始された事と，下腎杯のみ扢くれて収縮が開始された 症例が立位時には，臥位の $6 / 8$ 秒の遅延から $1 / 8$ 秒に短縮さ れて略々同㭙に収縮する傾向を見を事は，腎杯，腎孟内 圧の変化だけでなく，神経源性の起因も否定出来ないも のと思了。

\section{〔2〕腎孟の運動}

腎盖の収縮運動は，腎杯䅡部の収縮に連続して腎孟の 腎杯側から腎孟漏斗部を経て上部尿管へ中断する事なく 進行する蠕動運動が認められ，週期的に行われる。

第 2，3，4 例では，腎孟は腎杯側の収縮と共に腎孟 漏斗部へも蠕動的に収縮が進行し, 漏斗部は腎杯側へ緊 縮されて極期には上下腎杯及び漏斗部の収縮から求心性 の収縮像となり，蠕動収縮が尿管側へ移行するに従つて 腎孟の腎杯側から弛緩し始め, 順次漏斗部の蠕動的弛緩 となつている．第14図，第17図の写真でよく現われてい るが，第 1 例では腎孟漏斗部の腎杯側への緊縮が著明で はなく, 求心性の腎盂胿縮小注認められない。

腎盂の収縮の強さは，症例により異なりまた体位によ つても異つているが，造影剤の残留する範囲では，腎孟 䐑を全く閉鎖する収縮は認め引れない。しかし第 4 例 （第17図C）では腎雪漏斗部は完全に閉鎖した.

腎盂に扮ける計測值は，休止期住17〜23mmて，収縮極 期には $5 \sim 13 \mathrm{~mm}$ に減少し, 収縮値は $5 \sim 18 \mathrm{~mm}$ である。 3 例中 2 例は立位時腎盂の収縮以減弱し，1例は逆に収縮 值増加した。

腎孟の運動時間を第 3 表に挙げると，一般的には収縮 期治弛緩期より短く，立位をとると，共に延長する傾向 がある。

大原は腎盂の運動時間は臥位で $3^{3} / 12 \sim 7^{6} / 12$ 秒, 立位 ${ }^{13} / 16$ $\sim 4^{3} / 12$ 秒で臥位の方が立位より運動時間が長いと云つて いるが，著者の 3 例は立位時延長している。

山口 ${ }^{141)}$ は収縮は腎杯側より開始されるが，弛緩拡張 は腎孟尿管移行部より始まつて次第に固有腎孟の上方に

第 3 表 腎孟の運動時間（䕬数）

\begin{tabular}{|c|c|c|c|c|c|c|c|c|c|}
\hline 例 & 第 1 例 & \multicolumn{2}{|c|}{ 第 2 例 } & \multicolumn{2}{|c|}{ 第 3 例 } & \multicolumn{2}{|c|}{ 第 4 例 } & \multicolumn{2}{|l|}{ 平 } \\
\hline 哂数 & 臥 位 & 臥 位 & 立 位 & 臥 位 & 立 位 & 臥 位 & 立 位 & 臥 位 & 立 位 \\
\hline 収縮期 & 11 & 14 & 26 & 17 & 21 & 11 & 13 & 13.8 & 20 \\
\hline 弛緩期 & 20 & 13 & 18 & 16 & 21 & 16 & 24 & 16.3 & 21 \\
\hline
\end{tabular}


向つて蠕動的に行われるとしているが, 対象の 4 例には 全経過を通じて逆蠕動の所見はない。また大原は腎皿の 下腎杯側から収縮が開始されて後に上腎杯側の収縮とな り漏斗部へ向う症例挙げているが, 著者の所見では 上，下腎杯側の腎盂で同時に開始するか，上腎杯側で開 始されるかのいずれかて，腎杯の週期的收縮と同様腎孟 も下腎杯側から収縮が開始された場合はない。

腎杯と腎孟の週期的収縮運動の関係を見ると, Main$\mathrm{t} z$, Meese u. Wüllenweber (1938) ${ }^{84}$ のレ線キモグラフ ィーによれば，腎盕収縮時上腎杯は应張又は収縮してい る事もあり, 腎杯収縮時には腎盕は拡張中又は極期を示 す時がある，時には両者共に收縮している場合もあつて 何ら連絡むなく, 収縮時期は色从の配合をとり得ると言 3.

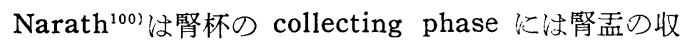
縮期を, 又 emptying phase には拡張期を仮定し腎杯 括約筋の収縮によつて腎孟より腎杯への逆流防止を重視 している. 小野 ${ }^{105)}$ 注レ線キモグラフィーの分析から腎 瑥の収縮蠕動は, 上腎杯の収縮に連続していると推論 し，上腎杯と腎孟の収縮数は同数々報告し，大原 ${ }^{107)} の$ レ線映画撮影法では，腎杯の週期的収縮は腎盂の収縮に 先行して起り蠕動的に腎盂へ移行し, 多数例は両者の収 縮数は同数となつて打り前述の腎杯固有の運動と思われ る 3〜4回の腎杯収縮も報告しているが, 小野, 大原共 に逆流現象については言及していない.

Johnson $^{64)}$ は腎杯より尿管を経て膀胱に達する上部 尿路の蠕動収縮運動を疑問視して, 括約筇で区切られる Pascalunits を提唱し, 本質的には腎杯, 督孟, 尿管 の運動は神経源的には関連のない運動と看做している. $\mathrm{Kiil}^{72}$ は尿路内圧の記録とレ線撮影を同調させた腎盂像 から, 腎杯と腎孟は無関係に収縮運動を行うと述べてい る.

こ〉で筆者の腎杯と腎孟の週期的収縮運動の関係圢, 臥位, 立位のすべての症例に掞いて腎杯の収縮開始は腎 孟の収縮に先行して各腎杯系の円蓋側で始められ, 蠕動 的に腎杯頝部から腎孟開口部の収縮となり, 腎杯内容を 腎孟に排出して中断する事なく腎孟の腎杯側から漏斗部 へ連続移行する。腎杯の螦動収縮時又は腎杯上り移行し た腎盂の収縮が進行すると或る腎杯では逆流現象があ る. 逆流の起る腎杯及び拡張する部位は不定であり, 逆 流によつて拡張した腎杯は収縮弛緩の基本的運動以外の 複雑な運動像を呈する事は既に述べた通りである。そし て最初開始された腎杯の収縮は, 明らかに腎杯内容を腎
孟から更に尿管へ排出する排尿機転の開始と看做され る. しかし逆流にょつて拡張した腎杯は, 主として䇛盂 の弛緩期に至つて再び収縮し逆流内容を弛緩した腎孟へ 再び排出する，桩張後収縮を見ない場合むあつて，ての 時は腎盂弛緩期又はその直後の休止期になつてから緩徐 な縮小像となつて自己の緊張状態（休止期）となり, 腎 杯内容は弛緩した腎盂へ単に移動したように見える.

腎㙉腎杯逆流現象後の腎杯運動恃, 最初開始された 蠕動収縮と異つて屡々縮小と表現されるもので，腎瑥の 収縮には移行しないでその後洪に休止期となる事から 尿排出機転としては間接的な運動である. 即ち逆流現象 をみない腎杯の週期的運動は必ず腎孟の収縮に直接蠕動 移行して両者の収縮数は同数であり, 腎監腎杯逆流現象 を生じた腎杯では腎跙の 1 回の収縮に対して直接及で間 接的の 2 つの腎杯収縮運動像を認め, 週期的収縮運動に おいては腎杯と腎孟が独立して収縮する事なく, 必ず両 者は関係ある運動像を示している。乙れは計測による運 動時相の比較から明らかである. 特に逆流現象を伴う腎 杯での直接的な収縮運動が $1 / 8$ 〜 $/ 8$ 秒の短時間持続した後 急速に拡張像となり, 逆流後弛綏期にある堅盂へ排出す る間接的な収縮像の方がむしろ強力な収縮を示主症例が 多く存在する事は, 上線学的に充分な連続像をもつて運 動の推移を観察しない限り腎杯と腎孟の運動像淕つた 解釈が行われるものと思う.

腎杯括約筋部の閉鎖能力惊, 乙線学的に Hennig ${ }^{53}$, Narath $^{99)}$, 小野 ${ }^{105)}$, 大原 ${ }^{107)}$, Catel $^{25)}$ 等によつて観察さ れ, こ〉に挙げた第 1 例上腎杯 (第 5 図) も明らかに䫋 部で収縮離断を示す，乙の腎杯括約筋の収縮閉鎖能を機 能的に見て, 腎孟収縮時閉鎖して腎孟よりの逆流を防 止し, 腎杯内尿貯溜に寄与するとなす代表的なものは, Haebler ${ }^{43}$ であり, Narath の collecting phase があ る. Johnson ${ }^{64)}$ も括約筋収縮機序の仮説を提唱した.

之に対して，Kiil ${ }^{22)}$ は上腎杯内へカテーテルを挿入 出来た 1 例で腎杯内圧を記録したところ, 陽圧又は陰圧 の特有な圧変動は認められず生理的食塩水を注入した時 初めて律動的な圧変動を認め, 腎盂へ直接注入した時と 全く同じの圧波動を認めて腎杯内圧の所見は, 腎杯運動 が乳頭部集合管から尿を滴下させるために必須の運動て あると云う事を示してはいないと述べ, 彼はまたレ線撮 影の同調法から腎杯碩部と腎孟の収縮とは無関係に起き るとし, 腎孟を少しく伸展させた例では腎孟収縮時造影

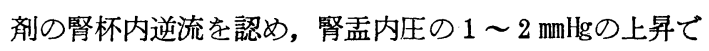
充分逆流が起きる事を報告した. との腎杯への逆流の証 
明は，腎杯括約筋は腎孟内圧の極く軽度の上昇にも耐え られない事を示していると述べている。また彼は腎孟の 排尿運動中腎孟内圧は收縮弛緩を区別出来ない程低いま 〉で，腎機能を保護するための腎杯，腎盐間の巧妙な機 能的協調作用は必要ではないとし，腎杯括約筋の運動は 明らかに尿運搬にとつて重要であると述べている。

著者の得た所見は腎杯上り腎盂への蠕動運動で，その 中に果して上述のような腎杯括約筋の協調機序が存在す るか否かを観察した。計測值から腎杯腎孟開口部と腎孟 の収縮時相を比較すると，第 1 例，上腎杯（第 7 図）は 腎孟の収縮極期を過ぎて弛緩後（極期より $5 / 8$ 秒後）に至 るまで収縮離断しており，第 3 例立位下腎杯 (第13図) は，腎孟収縮極期から $3 / 8$ 秒後の弛緩期に至つて収縮極期 となり次いで共に弛緩し休止期となつている.

$2 つ の$ 腎杯では夫々の腎孟開口部で腎盂収縮の間収縮 して逆流を防止出来る時相とする事が出来る. 事実第 1 例（第 5 図）では明らかに離断されたけれども，第 3 例 は立位で造影剤がある限り腎孟開口部で閉鎖離断を認め ないばかりか腎孟收縮に伴つて円蓋部への逆流が認めら れた。

また逆流により搪張を見なかつた第 2 例下腎杯（第10 図）と第 3 例臥位下腎杯(第12図)，腎盂開口部では，腎 孟收縮途上（腎孟收縮極期前夫々 $5 / 8,1^{3} / 8$ 秒）飞極期を 示し, 腎孟極期々は両腎杯は共に概ね弛綏期となつてい る. 腎杯間の逆流を生じた第 4 例，上腎杯（第18図）に あつても，腎孟開口部は腎孟の収縮極期に先行して極期 を示し，弛緩も腎盖に先行している．また第 1 例で柱上 腎杯に閉鎖離断が見引れたが，下腎杯汸終始離断能力は

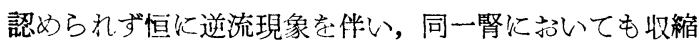
能力が異なる事忏明らかである。この様腎杯に忏腎孟 収縮時に腎孟内容の逆流を阻止出来る収縮時相と能力を 持たない腎杯が多数存在するので, 腎杯腎孟移行部の収 樎運動は，腎杯より腎孟へ移行する蠕動収縮の一過程で あり，腎杯括約筋の逆流防止機構が存在するとは考えら れず，腎杯の運動は腎杯ふら腎孟への尿運搬を目的とす る運動とみるべきものと思う。

辻 ${ }^{134)}$ に上れ《゙腎杯輪状筋の排列構造から見ると，腎 杯括約筋は腎杯輪状筋の最後且最強力なものであると同 時に腎盂輪状筋の最初のものと解するのが妥当と考える と述べ, 腎杯括約筋の独立性については否定的であり, 事実休止期に沙腎杯円蓋部，腎孟と共に腎孟開口部は収 縮期に比してはる加に長時間弛緩開口して抢り，Johnson $^{64)}$ のように腎杯への尿分泌によつて腎杯内圧が上昇
して一定の閾值に達卞る态で腎杯括約筋は収縮閉鎖して 腎瑥より逆流を防止していると云う所見は, 著者のいず

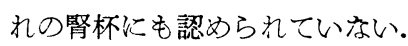

レ線胦画像の分析からすべての症例に見られた腎孟腎 杯逆流現象に就いて考察すると, 一回の蠕動収縮て尿管 側へ排出されなかつ腎㙉内容が伸展性を持つたいずれ かの腎杯へ逆流する事によつて腎杯腎盎内圧の上昇を調 節する事が出来ると思わ礼るのて, 腎乳頭への障害防止 に逆流現象の大きな意義を見出す事が出来上了. ての逆 流現象は, 研究认用いられた逆行性腎孟像にのみ見られ る病的所見でない事は Catel 等 ${ }^{25)}$ が正常腎の排洲性腎 孟像のレ線胦画による観察でも報告せる所である. また 揭載した連続印画で見るように腎孟収縮極期には相当高 度の内腔縮小があり, 当然腎盎内圧の著明な上昇が予想 されるのであるが，腎孟内圧に関して Lacus の興味あ る報告がある。

Lacus (1908） ${ }^{77)}$ は大の実験で督孟内圧が零であつて も蠕動に上り尿を腎盂から排出するととは興味があると 述べている. しかし Davis (1954) ${ }^{301}$ は Lacus の使 用した圧力計は蠕動を起す最低圧を測定出来る程の感度 がなかつたものと反対して人間の腎盂内圧は仰臥位て 8 $\sim 15 \mathrm{~cm}\left(\mathrm{H}_{2} \mathrm{O}\right)$ の值を発表している讨れぞも, $\operatorname{Kiil}(1957)$ ${ }^{7}{ }^{2}$ 㤝高感度の Urometry による研究では, 200例以上 の正常腎孟内压の Urometrogram で腎孟の収縮期と休 止期を区別出来る圧波動は殆んど認める事が出来ず， 3 〜 $4 \mathrm{~mm} \mathrm{Hg}$ の圧波動を示した少数例は尿路の拡張を認めた 症例であつたと述べ, 立位, 臥位共に腎孟内圧は低いま 〉に保たれて扣り，腎孟の压波動が全く上昇しないで毎 分 $8.0 \mathrm{cc}$ の尿が腎瑥から送り出されたと注目すべき結果 を報告している. この様に腎孟の収縮によつて尿の運搬 が行われる一方腎孟内圧が恒に低い状態に保たれている ものとするなら济, その調節は週期的収縮時の腎再腎杯 逆流現象によつて保持される以外にはない. Johnson ${ }^{64)}$ は上部尿路排尿機構に Pascal's Law を商用したが, 腎杯間及び腎孟腎杯間のみならず後述の腎杯収縮によつ て腎盂尿管移行部（第 7 四及び第10図）にも内容増加に 伴う拡張が見られる事は, Pascal's Law はむしろその 成因の説明に適用されるものであり，乙の逆流現象浔前 述の如く腎に対する安全弁的な存在と考える.

〔3]腎孟尿管移行部之上部尿管の運動

腎孟尿管移行部の収縮は腎孟漏斗部の収縮に直接連続 して蠕動的に移行し，4例共腎盘尿管移行部においては 内腔は完全に収縮閉鎖され，陰影は離断された。第 4 例 
第 4 表 腎孟尿管移行部の運動時間（朦数）

\begin{tabular}{|c|c|c|c|c|c|c|c|}
\hline 一症例体位 & 第 1 例 & & 例 & & & & \\
\hline 間 & 臥 位 & 臥 位 & 立 位 & 臥 位 & 立 位 & 院 位 & 立 位 \\
\hline $\begin{array}{c}\text { 収 縮 期 } \\
\text { (䧽断) }\end{array}$ & $\begin{array}{r}16 \\
(8) \\
\end{array}$ & $\begin{array}{l}10 \\
(2) \\
\end{array}$ & $\begin{array}{r}17 \\
(6) \\
\end{array}$ & $\begin{array}{l}14 \\
(6) \\
\end{array}$ & $\begin{array}{c}18 \\
(10) \\
\end{array}$ & $\begin{array}{l}13 \\
(4) \\
\end{array}$ & $\begin{array}{c}23 \\
(20) \\
\end{array}$ \\
\hline 弛緩 期 & 20 & 7 & 6 & 21 & 10 & 19 & 16 \\
\hline
\end{tabular}

は腎孟漏斗部の内腔も完全に閉鎤され，閉鎖した収縮が 蠕動的烙行している. その他の症例も腎盂尿管移行部 を離断した蠕動収縮は更に中断する事なく上部尿管へ伝 わり，尿管内容を膀胱側へ排出しつ〉下方へ移動する と，腎孟漏斗部の弛緩も腎孟側から蠕動的に腎孟尿管移 行部を経て上部尿管へ移行し膀胱側へ弛緩が進行してい る（第 1 例第 5 図 (c,d), 第 3 例第 14 図 (八), 第 4 例 第17図 (B,C,D).

腎孟尿管移行部で計測された運動時間は, 第 2 表の如 くである.

収縮期恃臥位 $1^{2} / 8 \sim 2$ 秒, 立位 $2^{1} / 8 \sim 3^{3} / 8$ 秒

弛緩期は臥位 $7 / 8 \sim 2^{5} / 8$ 秒，立位 $6 / 8 \sim 2$ 秒

臥位に㧧いては収縮期 $>$ 弛緩期 1 例

収縮期 <弛緩期 3 例で弛緩期が長い傾向があり, 立位で 饮 3 例とも收縮期 >弛緩期となつて運動時間々逆の傾向 を示している，また収縮離断している時間は収縮期の延 長之同じく立位で延長し, 臥位の ${ }^{2} / 8 \sim 6 / 8$ 秒から $6 / 8 \sim 24$ 秒となつているので, 立位では尿路内容の流下移動がよ り容易で抵抗が少く充分な收縮運動が行われ 1 個の収縮 蠕動波が長くなるものと考えられる. しかし正常腎で立 位を観察した 8 例中, 計測に適しなかつた 2 例も追㪤的 観察で腎孟尿管移行部のみならず腎孟の収縮期は上述の 3 例と同様立位時延長したが, 昭和 31 年報告した 3 例の 如く立位時逆に該両部の収縮期が短縮した症例もある。

腎盂尿管移行部と腎盃の收縮時相を計測点で比較する と, 腎孟収縮極期の直後に尿管移行部で収縮緊張が開始 されたものに第 $1 ， 2 ， 4$ 例があり，腎盂収縮進行中に 尿管移行部にも収縮が伝わり，共に収縮極期を示した第 3 例がある. 立位ては第 3 例は臥位と同じく共に収縮極 期を示しているが，第 $2 ， 4$ 例ては腎孟收縮極期には未 だ弛緩して抢り，臥位の時より蠕動収縮の移動が遅れて 該部の極期となつている. 此は立位時多量の尿路内容が 尿管へ流入する為に腎孟尿管移行部の収縮が遅れるもの と思われる.いずれも腎孟の収縮開始は腎孟尿管移行部 の収縮に先行している。

Oeconomos ${ }^{103)}$ は腎盂下括約筋を挙げているが，他に
は組織学的に証明した者はない。 Narath ${ }^{99}$ は組織学的 に注該括約筇は認めなかつたが，乙線学的には腎酉尿管 移行部は機能的に括約筋様の運動をなし, 腎盂弛緩時に 尿管よりの逆流を防ぐものとしている. Narath と同様 にレ線連続撮影法によつて観察した山口 ${ }^{141}$, Johnson ${ }^{64}$ も腎盂が収縮する時開いて腎孟内容を送り，尿管上部が 収縮して更に尿を膀胱側へ送る時は閉鎖して尿の逆流を 防ぐとしているが,こつで得られた所見は, 腎孟より順次 進行して来た蠕動収縮は腎孟尿管移行部に打いていずれ も内胿を閉鎖し，腎孟と尿管を離断するに至り，腎杯， 婜盂より一層強い収縮が行われたように見えるけれぞ も, 腎孟尿管移行部の収縮のみにとざまらず更に進行し て尿管上部に及び，約 $1 / 2 \sim 2$ 腰椎体の長さの収縮波とな り, その間の尿管像は全く消失し, 収縮波が螦動的に上 部尿管老膀胱側へ移動するのであつて, 腎孟尿管移行部. のみが特に強い収縮絞窄を示すものではない．また腎孟 漏斗部の内胿が完全に収縮閉鎖され，乙れに腎孟尿管移 行部より尿管上部の閉鎖離断が連続している第 3 例（第 14四（八））西つて，腎孟尿管移行部を中心に考元れ ば, 收縮波の膀胱側は収縮の進行, 腎孟側は弛䌊の途上 にあるので結果的には尿管内の尿の逆流が行われないけ れごも，乙れは腎杯におけると同様蠕動收縮が移動する 一過程で，腎孟尿管移行部の括約筇的収縮運動と解する のは妥当ではない。これらの所見は小野 ${ }^{105)}$, 大原 ${ }^{107)}$, 兼松 ${ }^{68)}$ 等と略々同様の結果である.

レ線学的研究以外の所見でも, $\mathrm{Kiil}^{22)}$ は尿路内圧計 己 乙線像の併用から腎孟尿管移行部は, 尿管特有の収縮圧 波形が記録された上端と定義され，収縮压波形から腎盐 尿管移行部々他の尿管部分と区別するととは出来ず, 他 の尿管部分でより高い振幅が記録された事は, 腎孟尿管 移行部は特殊な性質を持つていない事を示していると述 べ, 機能的括約筋の存在を否定している.

尿管上部では腎孟尿管移行部を閉鎖離断した収縮は次 第に膀胱側へ蠕動的に延長移動して $1 / 2 \sim 2$ 腰椎幅の映像 消失となり，尿管内容を膀胱側へ圧排しつ>下降し，収 縮波の通過後は腎側より逐次弛緩して腎孟内容は弛緩し 
つ>ある尿管内へ上方から流入し、再び陰影を現わすのが 認められる。

Narath $^{1003}$ は尿管を通常 3 つの機能的分節飞分讨, 各 々に collecting phase と emptying phase があつて 上部 $1 / 3$ 上下部 $1 / 3$ 江同時に満され，次の収縮波は上部 $1 /{ }_{3}$ の 尿柱を中央 $1{ }_{3}$ の部认運び, 同時に下部 $1 / 3$ が膀胱へ排出さ れる. 更に次の運動により中央部は下方 ${ }^{1} / 3$ 亿移動し, 同 洔に腎孟尿管移行部は開口して腎孟より排出された尿を 上部 $1 / 3$ に受け入れると云う分節的運動上なし，上部尿管 内の尿は中断しない流下運動に上つて膀胱へ運ばれるわ けではないと述べている。し玑しレ線キモグラフィーに よる木下 ${ }^{76)}$, 土屋 ${ }^{133)}$, 小野 ${ }^{105)}$, や三矢 ${ }^{91)}$, 大原 ${ }^{107)}$, 兼 松 ${ }^{68)}$ 等は腎盂より中断する事なく移動する蠕動波䒚認め て招り，特に兼松は 1 二の収縮輪が次第に下降するもの ではなく, 上部尿管の収縮は持続されたま〉, 下部尿管 の収縮に移行して一時は尿管の殆んど全体に亘り収縮を なし, 陰影の全消失の後上部尿管より弛緩して次第に下 方灾で再び陰影を現わす症例を観察している.

筆者の観察でも，第 $3 ， 4$ 例の立位では第 5 腰椎の高 さまで尿管像の消失を見, 収縮波は下降して撮影空外一 去り，弛緩む腎側より順次下方に移動して上方上り陰影 を露呈して来る所見が得られたので, 少くとも第 5 腰椎 の高さまでは懦動運動で分節的括約筋的排尿運動冲認め られなかつた。

尿管の運動観察には, 使用した像増倍管の撮影抱括範 曲注内径 5 时のため, 尿管運動の全般を観察する事が出 来ないので上部尿管に限定され, 尿管中央部以下を主と する時は腎杯, 腎孟との関係を明ら加する事は出来 ず，また両側の上部尿路を含む事が出来ないととが久点 で, 更に内径の大きな像増倍管が望ましい.

〔4〕腎杯, 腎孟, 腎孟尿管移行部の運動の関係

これまでに腎杯腎孟開口部及び腎孟尿管移行部での括 約筋機能がない事と, 特に腎杯の腎孟よりの逆流を阻止 する収縮時相と能力を有しない多数の腎杯について述べ て来た. Narath ${ }^{99100)}$ の提唱した腎杯と腎盂尿管移行 部の協調運動とよる尿排出説（第 1 図）によれば腎杯の collecting phase では腎孟は収縮排出期に相当し 腎孟 尿管移行部は開口して尿は上部尿管へ送られ，腎杯括約 筋は収縮閉鎖して腎盂よりの逆流は防止される（第 1 圀 A), 次にemptying phase になると腎孟は拡張期で腎 盂尿管移行部は閉鎖して尿管よりの逆流が防止されると 共に腎孟の陰圧注腎杯へ作用するとなし，逆流現象は全
く生じない機構であると言う.

尿の排出に対してての様な逆流阻止が必要な機構なら ば，すべての腎杯，少くこも上，中，下腎杯系等の大腎 杯の運動時相は腎盂尿管移行部に対し一致する事が必要 条件と思われるけれども彼の論文中すべての腎杯は同㭙 に運動するものではないと述べているので収縮時相には 矛盾した点も認められる.

レ線映画撮影法によつて観察した結果は, 既に述べて 来たょうに腎杯より順次上部尿管へ移行する蠕動収縮 で，乙の運動によつて尿運搬が行われる．との間にあつ て果してての様な機構が存在するか否かを観察する目的 で, 計測法による収縮時相を究明した.

筆者の所見から得られた排尿運動は, 上部尿路に強い 収縮運動が見られない休止期にも全尿路壁は恒に緊張の 変化を示して弛緩停止している事はなく内容に応じた緊 張度を有して抢り, 各腎杯壁には円蓋部ょり腎盖開口部 に向う不完全ながら迅速に行われる蠕動運動があり, 腎 杯内に分泌された尿を弛緩した腎盂へ送り出す運動が絶 えず繰返えされている．乙の時期には腎盘と上部尿管は 弛緩していて全く造影剤で満され，腎盂尿管移行部も弛 緩して閉鎖は認められないのてての場合には Narath の説流出出来ない. 次に休止期の内に上部尿路が充さ れると, 強力な蠕動収縮運動が腎杯円蓋部 から開始さ れ，週期的に行われる．この腎杯ての週期的運動は既に 詳細に述べた通り各腎杯系の円蓋部で同時に開始される ようである。

腎杯円蓋部で収縮が開始された時, 即ち Narath の emptying phase（第 1 区 B ）に相当する時期には, 計 測値の図表を参照すれば, 全例の腎盖尿管移行部は未だ 全く休止期にあつて弛緩を示すのみならず，第 1 例（第 7 図)，第 2 例 (第10図)，第 4 例立位 (第19図) では腎 杯の収縮が進行するに從つて休止期の映像より更に横径 を增加して上部尿管も拡張し, 腎盂内容の移動の影響が 現われているので, Narath の云う腎盖への逆流防止の ための収縮期と恃全く反対の腎孟内容の尿管移動を伴う 弛緩桩張期を示している．乙れは腎盂の収縮運動だけて なく，腎杯の収縮運動が尿管内への尿運搬にも寄与する 事を示すものである.

第 4 例（第18図）下腎杯円蓋側で収縮開始後，上腎杯 及び腎孟の収縮進行に伴つて逆流した腎杯内容を弛緩期 となつた腎需へ排出して再び縮小像となつた第 67 踹, $83 / 8$ 秒時は, 蠕動収縮 は既に腎盂から尿管移行部へ進行し て該部の収縮極期となつて離断しているので，第67檞か 
ら 3 铂の $3 / 8$ 秒間の腎盂像を抽出すれば，Narath の第 1 図 B と一致した像が得られる. しかしながら第67销よ りの円蓋部の縮小像は, 逆流による拡張から自己の緊張 度に還る運動で尿排出機転から見れば間接的な運動であ る事は既に述べた通りであり, 同一症例でも上腎杯は弛 緩休止期となつて抢り同じ運動状態ではなく，12秒時に は各部とも休止期となりいずれの部にも收縮運動は認め られない。

次に腎杯円蓋部で開始された収縮が移行して腎杯腎孟 開口部の収縮極期となり離断した第 1 例（第 7 図）上腎 杯で見ると, 腎杯運動の様式は異なるけれぞもその収縮 時相の同じ Narath の第1図Aの collecting phase と比較すれば，腎杯腎盂開口部の収縮離断の開始時は， 腎孟尿管移行部は明らかに弛緩しているが 1.5秒後洁腎 孟尿管移行部は腎孟より蠕動的に収縮を開始し, 離断後 より $1^{7} / 8$ 秒時には腎杯腎孟開口部も腎孟尿管移行部共に 収縮離断している（第５：（）。故に腎杯腎血開口部の 収縮期には腎盘尿管移行部㹥弛䌊期だけでなく收縮期と なつているととがある。また腎盐腎杯逆流現象を認めた 第 4 例（第18図）下腎杯腎孟開口部の第58絔, $72 / 8$ 秒時 の収縮時は腎孟尿管移行部の収縮像があり, 第 3 例（第 12図) 上腎杯腎孟開口部も逆流による拡镸より再び収縮 進行中の第50踹では 腎孟尿管移行部は収縮離断してい る. そして腎孟尿管移行部が弛緩途上にある時の第 62

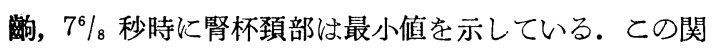
係は第 1 例下腎杯にも見られる.

逆に腎孟尿管移行部の運動時相吕ら腎杯, 腎盂の運動 像を見れば，腎孟尿管移行部の収縮極期には各腎杯系で は円蓋部の弛緩期又は既に休止期にあるものが多く, 小 数例ではあるが腎杯腎孟開口部の収縮期を示して抢り, 腎盂も共に 収縮極期を 示す症例（第 3 例）もあつて, Narath の協調的運動を適用する事は困難である.

Narath 汢括約筇が尿の逆流を防止し, 貯溜に関与す ると考え，Johnson ${ }^{64)}$ は括約筋に対して上方よりの压 は括約筋を開口せしめ, 下方よりの圧は之を閉鎖せし め, 尿を膀胱側へ一定した方向に送り, 逆流を阻止する と仮定したので, 下方への排出期に先行して括約筋恒 に収縮閉銷していなければならない事になる。しかし筆 者の所見では螦動運動は週期的に行われ, その間に休止 期があり腎杯䅡部, 腎孟尿管移行部に限る収縮離断像は 認められなかつた。腎跙内造影剤が減少した $3 \sim 5$ 分後 に掞いても休止期沙杯々尿管像は著しく狭細上なり時 には殆んど認め難くなるが，乙れは尿路内容に応じた緊
張度を示しているものと考えられ，括約筋的収縮とは解 されない。

週期的蠕動収縮が通過後，尿管も腎孟側から満されて 休止期が完成される事は，Kiil ${ }^{72)}$ が腎孟と尿管内圧の記 録から，腎盂と腎盂尿管移行部との間に内圧の傾斜を見 出すととが出来ない事から, 腎孟の filling phase に 证腎盂尿管移行部は開いた㐘〉であり，休止期にあつて は腎孟と限定する事なく上部尿管も态た reservoir と して働くととを暗示すると述べているが, 筆者の所見か らも同意見である。

曾つてレ線胦画供覧に際し，腎杯頚部及び腎孟尿管移 行部において收縮時結果的に逆流が阻止されている映像 を報告したが, 詳細に分析すれば蠕動運動の一過程と考 えるべきで, 分節的協調運動は存在せず, むしろ逆流現 象によつて腎杯腎罡内圧が調節され，腎乳頭集合管への 逆流圧が防止されるものと思う.

レ線映画撮影法も連続撮影法の一種には相違ないけれ ぞも, 短時間内に数十乃至数百枚の腎孟像が得られ, 現 今行われているレ線連続撮影法に比すればその連続性は 比較にならない。計測值よりすれば，上部尿路の週期的 蠕動収縮が腎杯に始忍つて上部尿管を通過して再び休止 期に至るまでには, 少くとも10秒, また屾それ以上の連 続した観察時間が必要である. Narath ${ }^{100)}$ の如く 2 秒間 に 4 枚だけ撮影出来る装置をもつてするならば，その間 に認められる上部尿路の運動の中で腎盖を中心とする時 は, 腎杯から上部尿管までの全運動を観察出来ないであ ろろし, Johnson ${ }^{64)}$ のうに $1 / 2 \sim 2$ 秒間隔で撮影された 像からは充分な連続性が望めない事は, 計測伯を一定間 隔で抽出する時, 蠕動運動も 2 計測部で交互収縮運動 として観察されるからである。 また連続性にそしい像か らは同じ程度に陰影が狭小を示しても, それが収縮進行 中であるか，又は弛緩途上にあるものか，収縮極期を継 続しているものか判定は困難であり, てれにょつて推論 するならば, 他の部分との運動時相の比較検討は甚だ当 を得ていない。事実多くの腎杯には逆流現象があつて,

腎杯, 腎盂間に複雑な運動像が見られる事は, 乙線映画 像の分析により知り得たものであり，上線映画による観. 察の多くが, 蠕動運動としているのに対してレ線連続撮 影法の観察では, 分節的括約筇的収縮運動と看做され, 時に腎杯と腎孟の収縮が関係なく行われるとしているの は, 腎盂の運動期の前後に逆流した腎杯の拡張像乃至は 収縮像が現われるので, 種々異つた所見として報告され ているものと思う。. 
第 5 表 運動週期（莓句数）

\begin{tabular}{|c|c|c|c|c|c|c|c|}
\hline 例 & & 体位 & I & $\mathbb{I}$ & III & IV & 間 \\
\hline 症例 & 1 & 臥 & 85 & 76 & 114 & 102 & $94 / 8 \sim 142 / 8$ 秒 \\
\hline \multirow{2}{*}{ 症例 } & \multirow{2}{*}{2} & 臥 & 134 & $i 22$ & 95 & 86 & $106 / 8 \sim 166 / 8$ 秒 \\
\hline & & 立 & 55 & 52 & & & $64 / 8 \sim 67 / 8$ 秒 \\
\hline \multirow{2}{*}{ 症例 } & \multirow{2}{*}{3} & 臥 & 121 & 82 & 114 & $\ddot{i} 12$ & $102 / 8 \sim 15 \mathrm{i} / 8$ 秒 \\
\hline & & 立 & 95 & 102 & & & $117 / 8 \sim 126 / 8$ 秒 \\
\hline \multirow{2}{*}{ 症例 } & \multirow{2}{*}{4} & 臥 & 155 & 130 & 115 & 128 & $143 / 8 \sim 193 / 8$ 秒 \\
\hline & & 立 & 50 & 88 & & & $62 / 8 \sim 11$ 秒 \\
\hline
\end{tabular}

〔5]呼吸運動と週期的收縮運動との関係 呼吸運動に伴つた尿路内圧の変動飞就いては, Davis ${ }^{30}$ 注 $1 \mathrm{~cm}\left(\mathrm{H}_{2} \mathrm{O}\right)$ の腎孟内圧の変化を記錄し, $\mathrm{Kiil}^{722}$ 仗 上部尿路の休止期汇呼吸運動と同調して, 吸気中に頂点 飞達する $2 \mathrm{~mm}(\mathrm{Hg})$ 以下の压波動学認め, 督孟内で最 も大きく記録され, 共に腹圧の変化によるものであると している. Lapides ${ }^{78)}$ は尿管の毉張度と週期的収縮は中 枢神経系及びすべての神経細胞々は全く無関係であり， 尿管震動の開始及び維持に対する適切な刺战は排泄され た尿によつて尿管平滑筋線維 が伸展 される事にあると し，排出された尿量の変化によつて蛹動頻度が変化する としている. Johnson ${ }^{64)}$ はレ線連続像から Lapides と 同じく上部尿路への唯一の刺战は，尿路自体内の液圧 (尿)で, 分節の収縮は液圧がその分節に対する闇值に 達した時に現われると仮定している.

若し尿路内压の上昇が収縮発現の刺韩となるならば, 呼吸運動, 特に吸気時の他動的腎盂内压上梨によつても 蠕動収縮が開始されるのではないかと云う疑問がある. 木下 ${ }^{76}$ はレ線キモグラフィーにて呼吸を一時停止せしめ て, その間に腎盂より膀胱に向う蝫動運動を観察し, Kiil 注収縮律動と頻度は呼吸王変動には無関係であると 報告しているが，著者は吸気時に腎の下方移動と共に腎 孟像の縮小を認的, 腎孟内压の上昇を充分予想出来る症 例を得たので之に就いて考えると, 第 1 例(第 7 図)で週 期的収縮通過後, 休止期に移行する第 63 繁, $77 / 8$ 秒時上 り第 75 浖, $9^{3} / 8$ 秒時に至る間は, 吸気時に相当して腎の 下方移動に伴い，中，下腎杯系と特に腎孟に均等な縮小 が認められ，計測值の急激な減少が見られた。 この時は 週期的収縮のような逆流現象は認められていないので腎 杯，腎孟の縮小につれて弛緩した上部尿管内への造影剤 圧出々，一時的の腎杯腎孟内圧の上昇は推察される所て あるが, この均等な縮小の後は再び弛緩した休止期に還 えり, 3 秒後に週期的収縮運動の開始となって, 吸気に
よる縮小が週期的収縮を誘発させる所見は認められなか

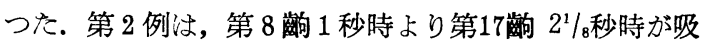
気の頂点で, 腎孟横径 $21 \mathrm{~mm}$ 幅より $2.5 \mathrm{~mm}$ の縮小が見られ た. この時吸気に一致して上, 中腎杯で週期的収縮が開 始されたけれぞも，134敵後 $\left(16^{6} / 8\right.$ 秒後) に開始された 週期的運動は呼気の中間で開始となり直接関係は認めて いない．他の例では呼吸運動々よる尿路の縮小を計測上 明らかにする事骀出来なかつたが, どの症例も週期的蠕 動運動の発現は呼吸運動と注一定の関係は認められなか つた.

\section{[6]運動週期}

1 分乃至 1 分 30 秒間の連続フィルムから得られた収縮 運動の週期を, 最も明膫に観察出来る腎盂尿管移行部の 離断を以つて計ると，第 5 表の如くである.

卧位では $8^{4} / 8 \sim 19^{3} / 8$ 秒に 1 回, 立位では $6^{2} / 8 \sim 12^{6} / 8$ 秒に 1 回の週期的蠕動運動が認められ, 一般に立位では 臥位より週期が短縮されてより頻回に行われる傾向があ る. 大原は臥位 $7^{1} / 12 \sim 11^{9} / 12$ 秒, 立位て $2^{5 / 8} \sim 6^{6 / 8}$ 秒の週 期を観察して立位時著明に頻数となると述べているが, 著者も同じ傾向を認めた．時間の経過による変化では, 第 2 例に多少短縮される傾向があるが，3 分後に 104 踹 を数え特別な傾向は認められなかつた.

[7]造影剤の腎孟内消失時間

注入された造影剤の消失時間をもつて尿路の運搬機能 を推察した. 70\%, ウロコリンを卧位 $3.0 \mathrm{cc}$, 立位 5.0 cc以下の注入で各腎杯系まで満たす量にとぶめ, 尿管力 テーテル抜去直後より、観察した. 消失㭙間は第 6 表の如 くである.

臥位に拧いては 4 分 09 秒乃至 8 分 46 秒, 立位で 1 分 20 秒乃至 4 分 48 秒て腎杯腎孟より造影剂は消失した。一般 に卧位上り立位に括いて排泄が早く，略く $1 / 2$ 又はそれ以 下に短縮されている。これは70\%ウロコリンの比重が 1.39 でり，尿と比較すれば著しい差があるために臥位 
第 6 表 造影剤腎盂消失時間

\begin{tabular}{|c|c|c|c|}
\hline & 体位 & $\begin{array}{c}\text { 注入量 } \\
\text { (cc) }\end{array}$ & 消失時間 \\
\hline 症例 1 & 臥位 & 2.0 & 4分 20 秒 \\
\hline \multirow{2}{*}{ 症例 2} & 臥位 & 3.0 & 8 分 46 秒 \\
\hline & 立位 & 5.0 & 4分 48 秒 \\
\hline \multirow{2}{*}{ 症例 3} & 臥位 & 2.5 & 4分 09 秒 \\
\hline & 立位 & 3.8 & 1分 20 秒 \\
\hline \multirow{2}{*}{ 症例 4} & 臥位 & 3.0 & 8 分 10 秒 \\
\hline & 立位 & 4.6 & 3 分 21 秒 \\
\hline
\end{tabular}

でー一層貯溜して生理的排泄より延長するであろうし， 立位ではより一層流下が促進される事を考慮しなくては ならないが, レ線学的研究では多少なりこもこの影響は 避けられない。 Hanley ${ }^{48}$ 㳉レ線映画の忘用について, 卧位より立位とした時腎孟内の造影剂が数秒内に消失す るを見てその比重の影響を重視しているが，しかし生亀 ${ }^{599}$ は体位による腎盂排出尿量を観察し, 頭側を高くして 行くと最も多く，頭側を低くすると尿が腎盂内に眝溜さ れ易い結果を示しているので, 差異のすべてが造影剂の 比重のみに帰せられない，また腎盖が腎杯側へ拡がる一 方, 尿管側で漏斗状となつて尿駆出に法適さない形態 で，腎盂収縮時腎杯へ逆流し甚だ能率の悪い排尿運動が 行われ，乙れが特に臥位に执いて著明に現われる事と， 立位では腎杯腎孟の収縮が緩徐行行われ且臥位の時程強 い収縮を示さない傾向がある事汸, 吾々人間の日常生活 に扒いては上部尿路に対して臥位をとる時間よりも立位 をとつている時間の方が長いのが通常であり, 従つて尿. 運搬能力も立位時の尿路内容に順応して立位ではょり一 層円滑な排尿機構が行われるようになつていると考える ならばてつでもまた造影剂の比重の影響の及と判断する 事は出来ないであろう.

Alken 等 ${ }^{5)}$ は， 50\%ウロセレクタン 4.0cc の逆行性 注入後透視を行い， 1 分 10 秒で 尿管 カテーテルを找去 し， 1 分50秒で直立位として観察すると， 3 分で腎盖上 部の造影剤は娍少し, 5 分55秒で腎孟内造影剂は認め られなかつた症例を記載して大体 3 ～ 8 分で消失するむ のとしている.

筆者は, 70\%ウロコリンの臥位 $3.0 \mathrm{cc}$, 立位 $5.0 \mathrm{cc}$ 以 下の注入量に限定して, 卧位 10 分, 立位 5 分以内の腎盂 内消失時間をつて正常範囲とし, 今後の病的腎の尿路 内停滞について比較考察する資料とした。

\section{第 II 編 遊走督上部尿路排尿運動}

遊走腎の症状は甚だ多岐て, 泌尿器科的症候のみなら
第 24 計測值, 症例 1 , 右腎, 臥位
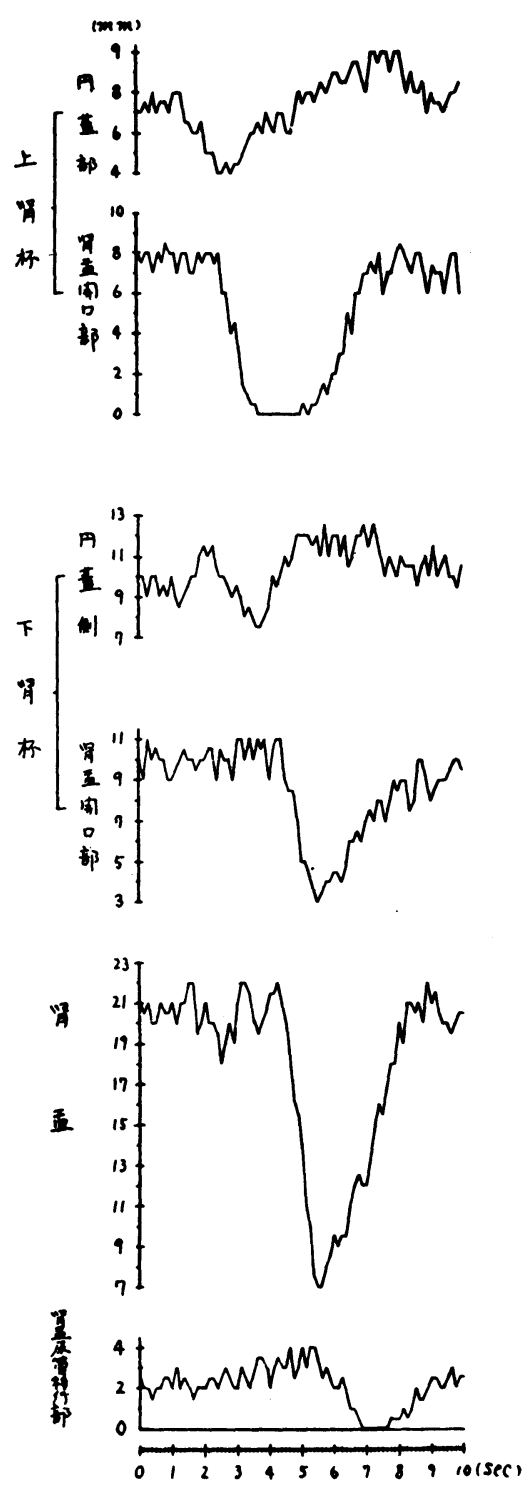

ず屡々消化器症状を主訴としたり, 時には所謂 Dietl's crisis として側腹疝痛発作と共に乏尿, 無尿, 呕気, 呕吐の後, 虚脱に陥り, 他科疾患と鑑別困難なる場合が ある. 清水の遊走腎に関する広範なる研究 $\left.{ }^{(16)}-124\right)$ によれ ば, 遊走腎症状は腎の移動度に一致せず生理的範囲を越 えた腎移動の結果, 血管の伸長, 腎孟, 尿管の屈曲或は 捻転によつて生ずる血行障害と尿の停滞の程度に比例し て種々の症状が誘発され, 腎被膜と腹膜との瘾著牽引に よつても症状を現わす事が明らかにされた．また臥位, 
第25図計測值, 症例 1 , 右腎, 立位
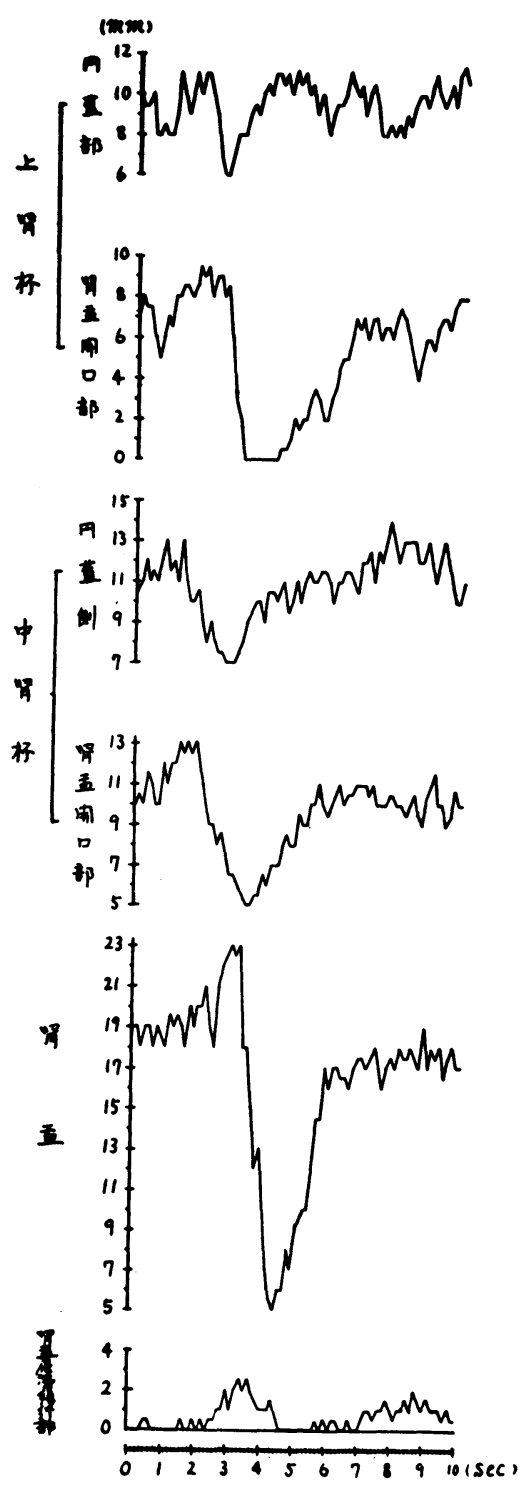

立位時のレ線腎孟像の比較観察を行つて, 腎孟像の変化 と自覚症状の原因とは密接な関係があり腎孟変形像は本 症の診断に当つて腎下降の程度, 尿管像の変化等と共に 極めて重要な所見で, 立位腎孟撮影法の重要性を強調し ている.

私は16ミリレ線映画撮影によって14例21患側の遊走腎 におりる逆行性腎盂像学撮影して卧位，立位時の上部尿 路排尿運動像を分析し，上線像増倍管による腎孟透視法 を併用して造影用の排泄状況を観察した結果 $2 ， 3$ の新
知見を得たので報告する. 本文の要旨は第 8 回日本泌尿 器科学会中部連合地方会及び第45回，46回，47回，日本 泌尿器科学会総会で発表し, 映画を供覽した。

\section{I 自験例}

男子 4 例，女子 10 例計 14 例 21 患側の遊走腎について卧 位, 立位の逆行性腎盂映画像から上部尿路の運動を観察 し, その内 7 例は腎固定術前, 後の排尿運動を比較検討 した.

造影済の注入量访各症例臥位 $3.0 \mathrm{cc}$, 立位 $5.0 \mathrm{cc}$ 以下 とし, 撮影は臥位では尿管カテーテル抜去30秒後, 立位 は抜去直後から開始した。腎遊走度の分類は，清水及び 吉川の分類 ${ }^{123)}$ に従つた。

症例 1.48 才，男子

主訴 血尿

診断 両側遊走腎(右腎遊走第 III 度, 左腎遊走第 II 度) この症例は膀胼鏡検查によつて左腎血尿を確認し，立 位腎盂像で上記の腎遊走を認めたが, 遊走度の強い右側 腎には臨床上何ら症状を訴えなかつた症例である。

所見 右側腎臥位

第61藠よりの計測値をグラフに示すと第24図で，運動 像は第26困である。

腎孟は双枝型の腎杯に分かれ，下腎杯下端は第 II 腰椎 下縁の高さにあつて呼吸運動により $1 / 2$ 腰椎幅の移動が認 められた.

週期的蠕動收縮は正常腎と同様に腎杯円蓋部より腎孟 を経て尿管上部へ移行する状況は第26図の写真のように 明らかである. この症例では上腎杯の収縮進行によつて 下腎杯への逆流現象が著明で, そのため下腎杯円蓋部収 縮は 1 秒遅れて開始されている.上腎杯から腎盂の収縮 に移行すると下腎杯への逆流が一層著明となり, 下腎杯 の収縮についで腎孟収縮極期に至ると腎孟内容は既に弛 緩した上腎杯へ逆流し, 上腎杯円蓋部の拡張となり上, 下腎杯は交互に収縮拡張像を呈している。

第24図の計測値による運動の推移も正常例と異る所は ない. 上腎杯像を見ると第 26 図 $1 ， 2$ のように吸気時の 腎下方移動を伴つて上腎杯の屈曲が現われ，呼気時には 上方に移動すると腎杯は直線的に延びている像が得られ た. この現象は腎の前傾又は後傾のみでは説明出来ない ので生体内では立位にょる腹部の圧迫によつて腎杯の変 形を来たすものと考える.

䌮動收縮運動は $5^{6} / 8 \sim 7^{3} / 8$ 秒の调期で行われ, 7 分 12 秒 で造影剂は腎杯，腎孟から排泄された。

右側腎立位

70\%ウロコリン $5.0 \mathrm{cc}$ 逆行性注入.

腎盂像註第27図のように腎の下垂が著明で下腎杯下端 
1）第10嚙

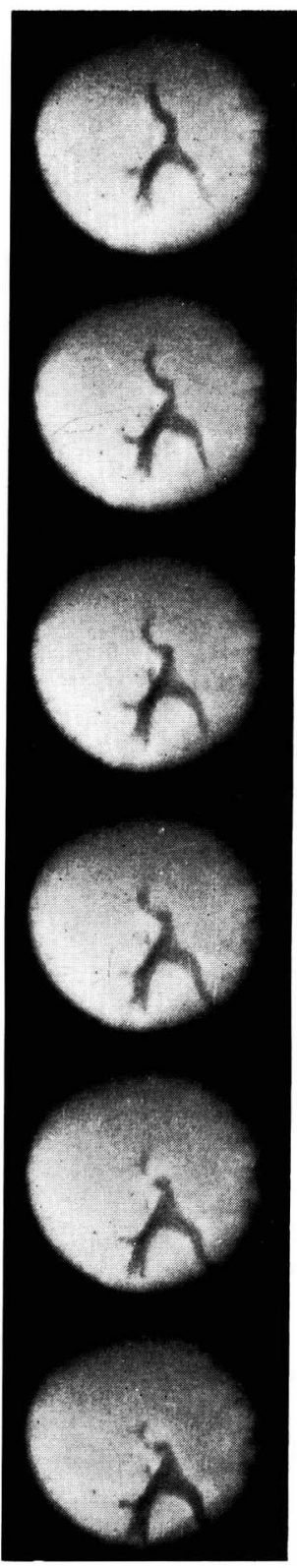

第26図 症例 1 , 右腎, 防位

2) 第30㰅

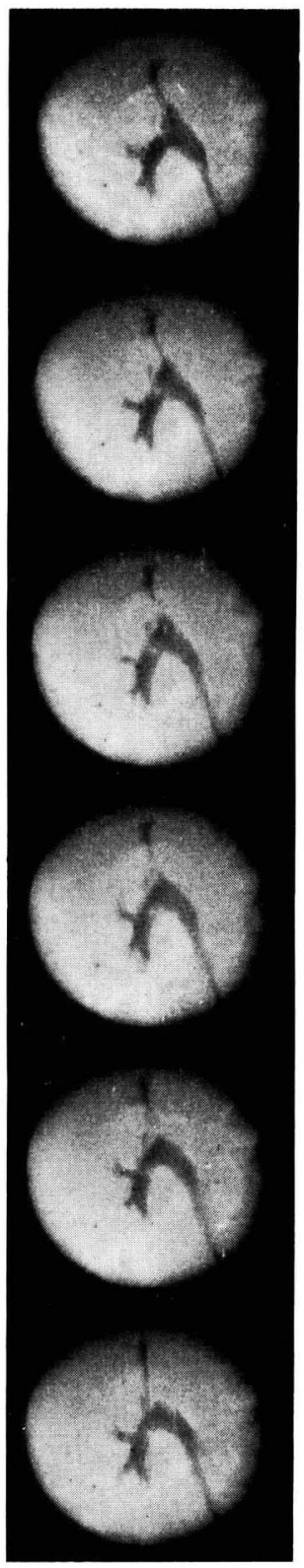

3）策,45苟

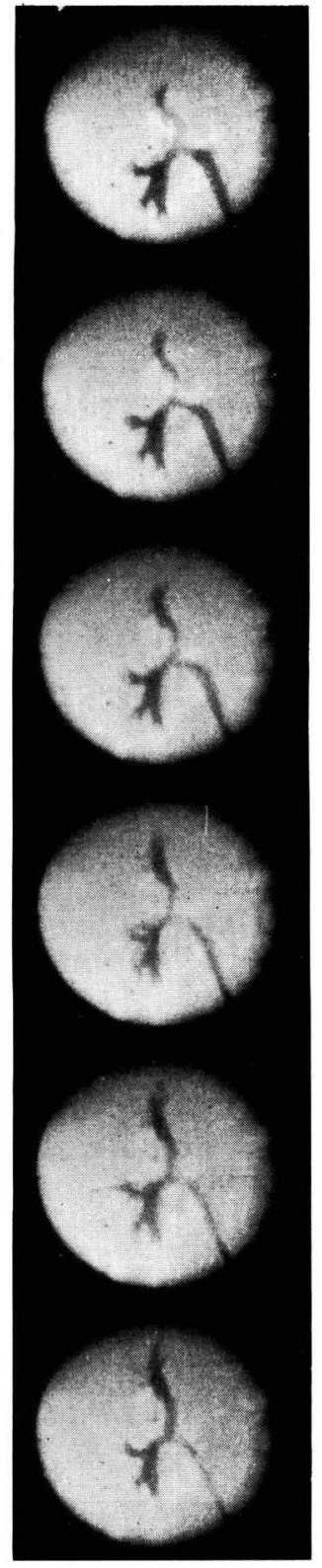

4）第60粉句

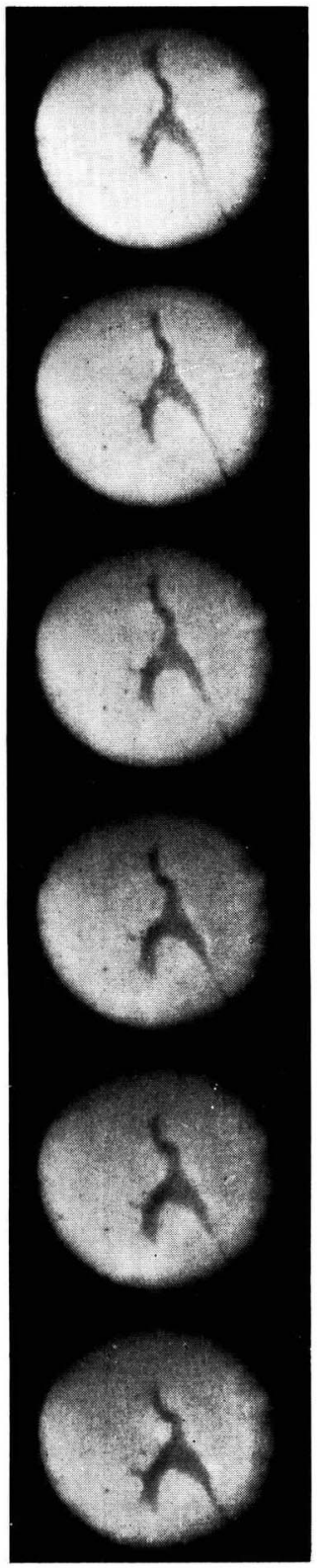

1）上腎杯収縮開始，腎杯用曲像

2）下腎杯収縮と腎盘収縮開始

3）腎孟収縮極期と尿管収縮

4）尿管弛緩期 
第27脳症例 1, 右腎, 立位
1) 第 5 蹒句

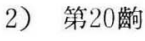
3）第30嘆
4）第36跔
5）第55萄
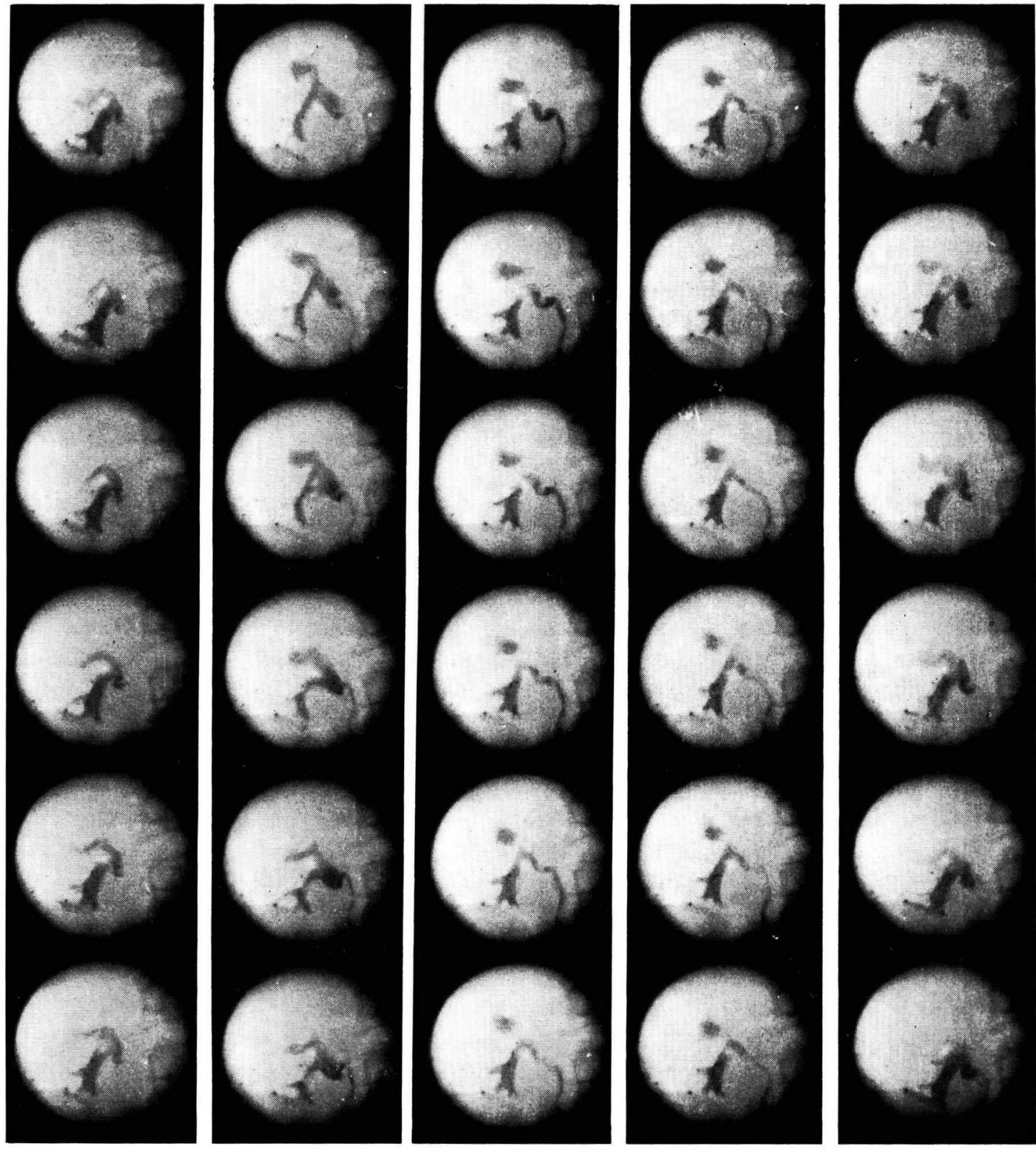

1）上腎杯収縮期，吸気時上腎杯届曲著明

2）下腎杯収縮期，弛緩せる上腎杯へ逆流

3）腎孟収縮極期，上，下腎杯への逆流著明

4）上部尿管の収縮期, 腎盂弛緩期

5）腎盘，尿管の弛緩期，次回の蠕動が上腎杯にて開始 
第28図 症例 1 , 左腎, 臥位

1. 第57萄

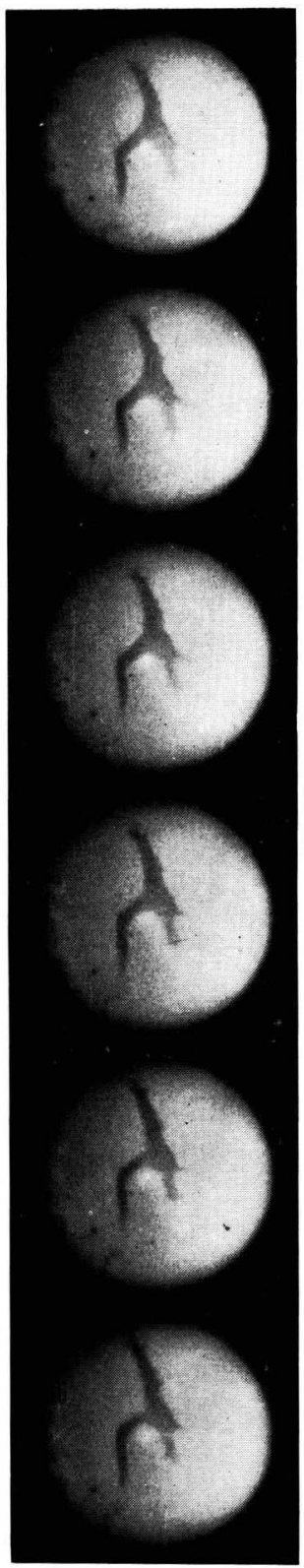

2. 第63龆

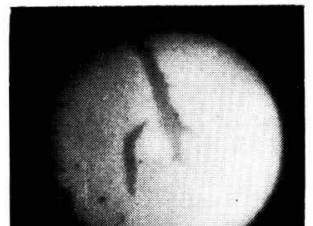

(*).
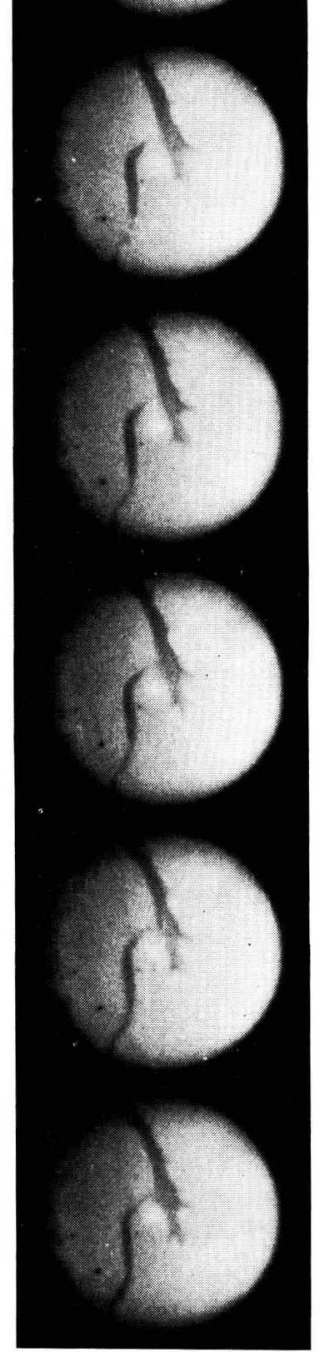

1.上腎杯より下腎杯の収縮像と腎孟収縮開始

2. 腎跙収縮極期

3. 上部尿管収縮期

4. 上部尿管驰緩期，尿管届曲部で陰影の中断を示す.
4. 第82唃
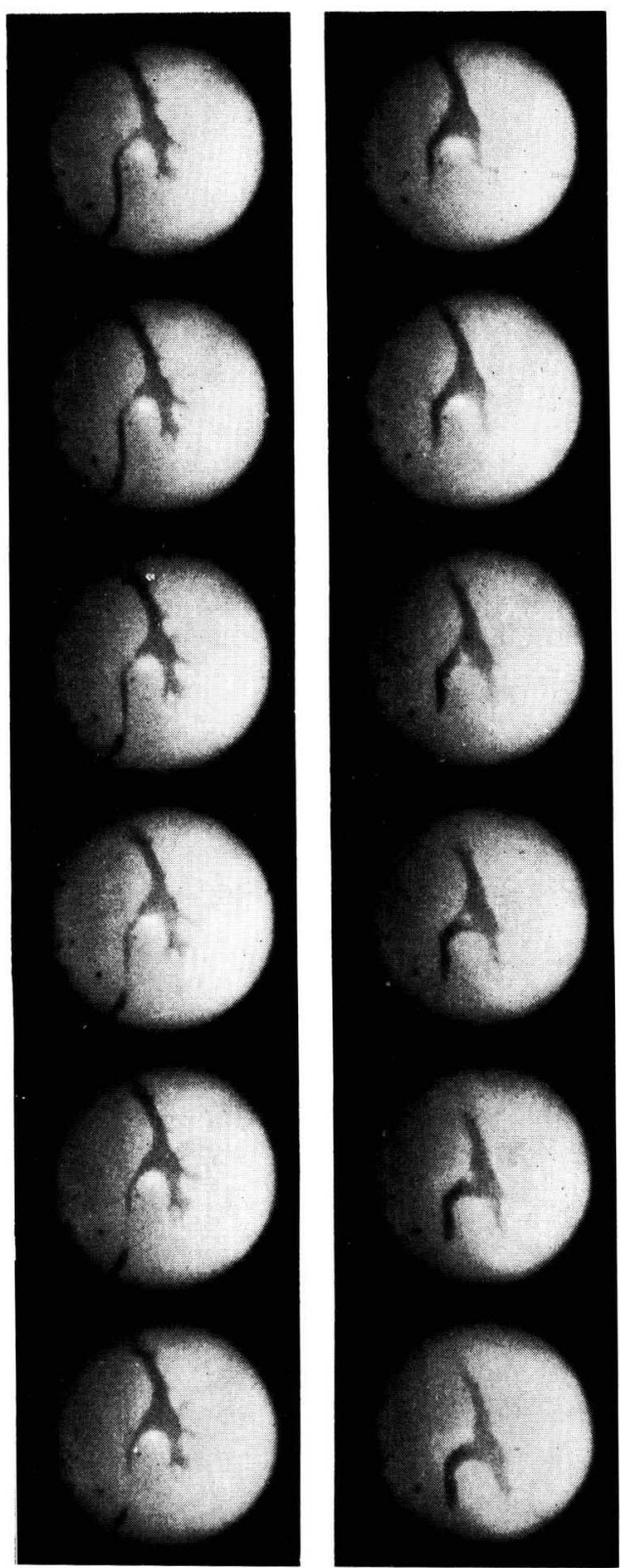
第29这 症例 1 , 左腎, 立位

1. 第 60 䔻

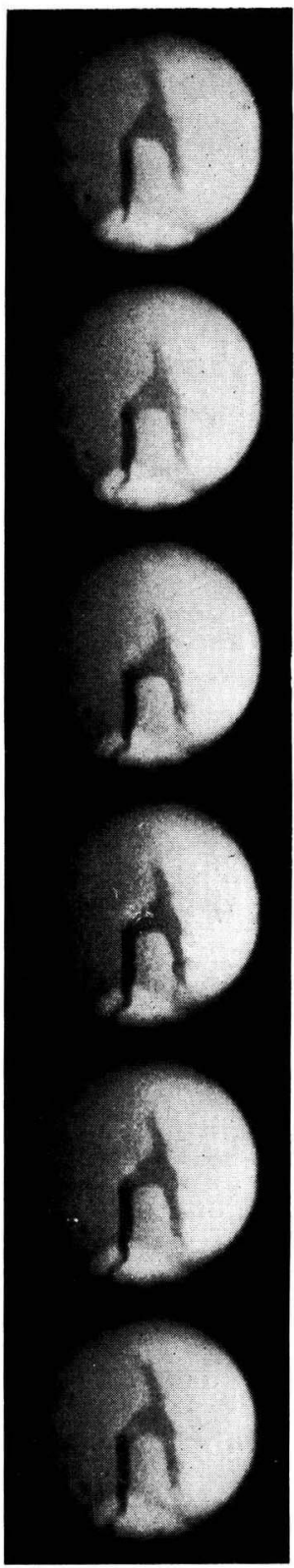

2. 第67齣

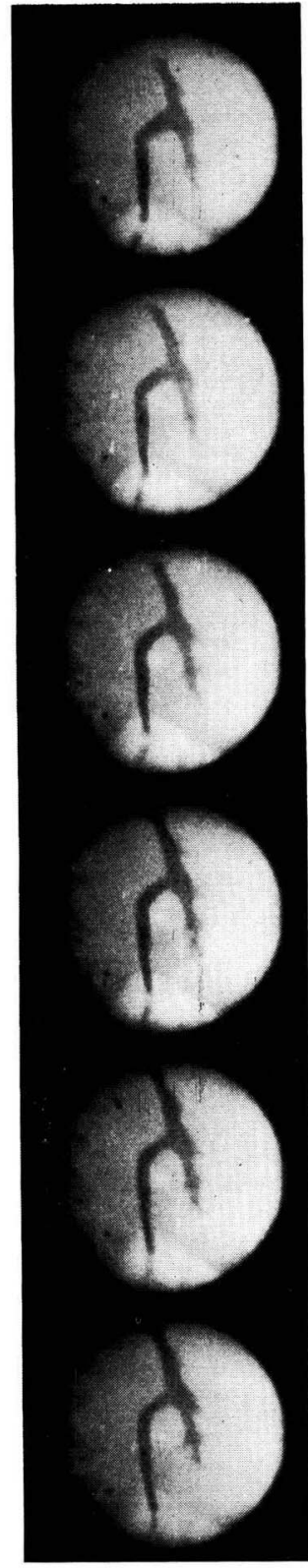

3. 第 74 路
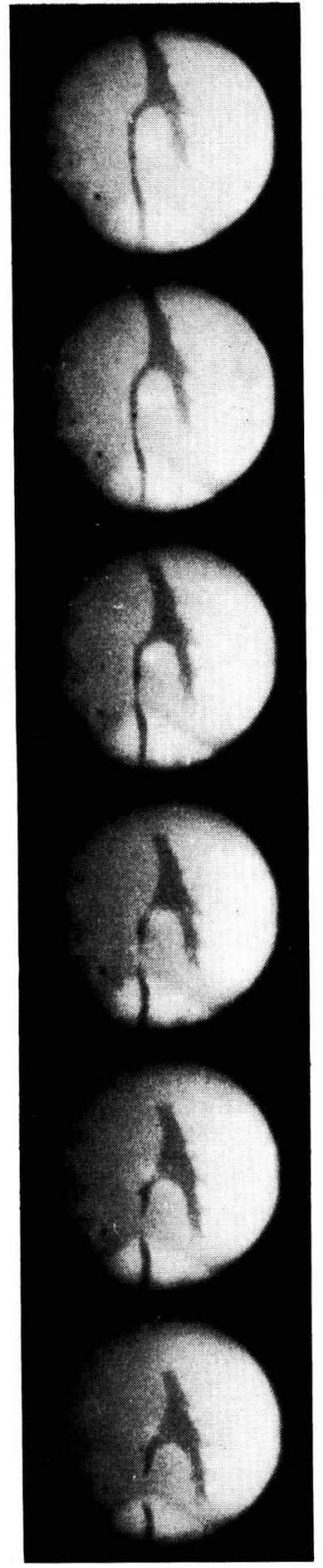

4. 第80嘆

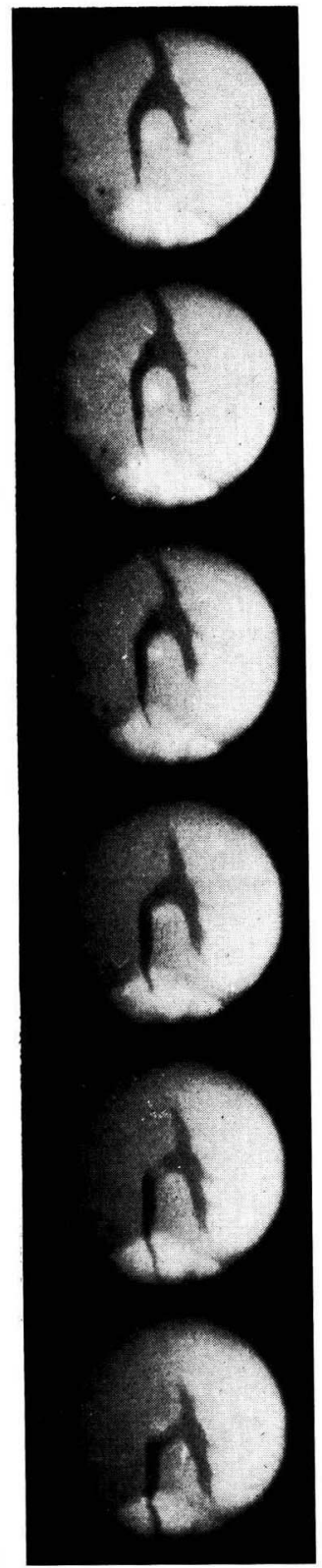

1. 腎杯収縮期, 尿管届曲部上の造影剂停滞著明

2. 腎衁収縮極期

3. 尿管収縮期, 腎杯腎血弛緩期

4. 尿管弛緩期，上腎杯にて次の蠕動開始 
第30図計測值, 症例 2, 臥位

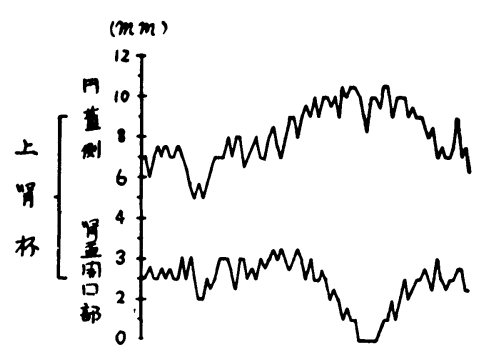

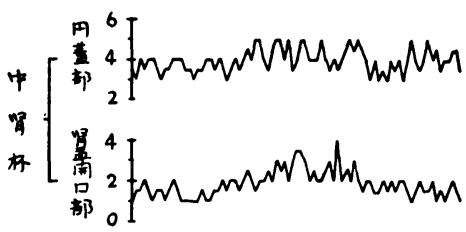

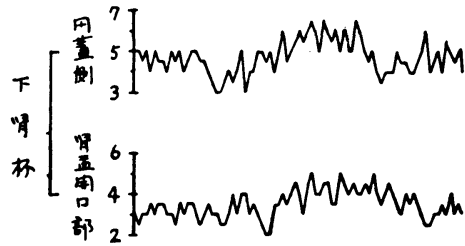

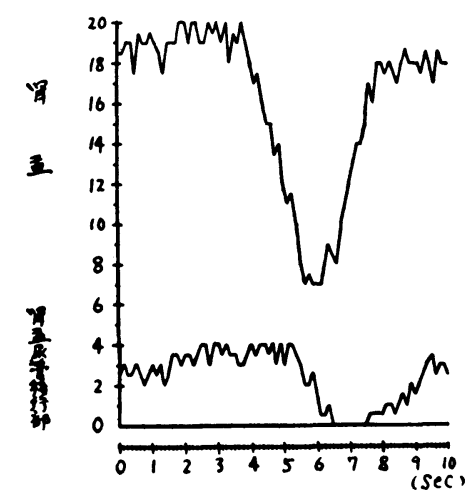

は腸骨櫛の高さまで下降し, 腎孟漏斗部の屈曲が認めら れる. 撮影第 140 經より 10 秒間の各部の計測値は第 25 図 に示す. 収縮運動の経過恃立位時にも上腎杯, 下腎杯,

腎孟, 上部尿管の順に週期的蠕動収縮が行われて臥位と 異つた点は認められない。しかし立位時には腎杯間及び 腎孟腎杯間の逆流現象が臥位よりも著しく認められるの は腎孟尿管移行部の屈曲が通過障害の原因となつて造影 剤の腎孟内貯溜を招来しているものである.

第27図 1，5で見るょうに吸気時上腎杯が外側へ屈曲 して水平位をとり，卧位時よりも一層著明となつてい る. 斜位の透視で腎上極は後方へ, 下極は前方へ転移し て吸気時に腎の後傾が増強する事を確認したが，ての上
第31図 計測値, 症例 2 , 立位
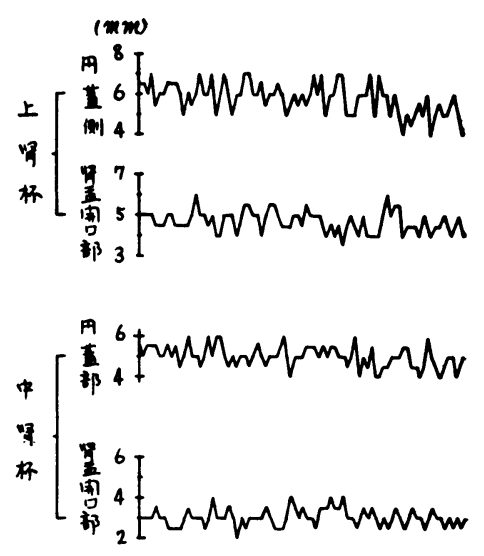

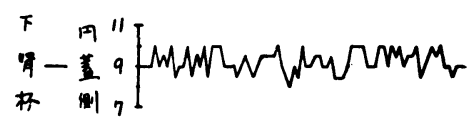
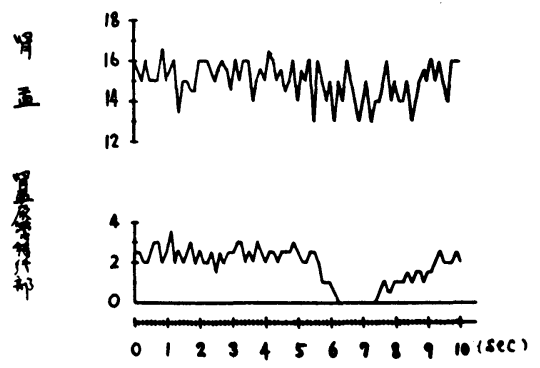

腎杯の変形像は下腎杯像との関係から腎の前, 後傾では 理解し難い現象であり, 吸気時の圧迫で腎上極の屈曲を 来すものと思う.

収縮運動の週期は, $52 / 8 \sim 84 / 8$ 秒で臥位と略々同様であ る.

腎孟内造影剤の消失時間は 6 分 04 秒で, 臥位の 7 分 12 秒とは小差であり, 立位をとつても腎孟内容は尿路内に 停帯するようである.

左側腎臥位（第28図）

造影剤注入量 $2.8 \mathrm{cc}$ で全腎像を現わし, 右側腎とは全 く異つて腎杯分岐の少い小腎杯アンプル型の腎孟像で, 吸気時下腎杯下端は第 2 腰椎下縁より第 3 腰椎上縁の高 さまで移動し, 尿管は第 3 腰椎中央の高さで腰筇辺縁と 交叉し屈曲を示している.

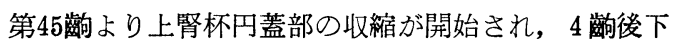
腎杯の収縮となり,蠕動的腎孟の収縮に移行している. (第28図 1) $24 / 8$ 秒後腎盂收縮極期を示し腎盂漏斗部は 
極めて狭小となつているが完全閉鎖には至つていない. 尿管側へ排出された造影剂は，尿管届曲部より上部に一 時貯溜して紡鍾形を呈している. 腎孟漏斗部の収縮が蠕 動的に上部尿管へ進行すると紡鍾形の尿柱（造影剤）は 次第に膀胱側へ移行し, 䗇動收縮も尿管屈曲部で中断す ることなく移行している．弛緩の経過も腎杯側より尿管 側へと蠕動的に認められ正常腎と同様である（第28図 $3,4)$.

運動週期は $4 \sim 7^{3} / 8$ 秒て, 3 分54秒後には腎孟内造影 剤は全く排泄された。

左側腎立位 (第29図)

造影昘注入量 $4.5 \mathrm{cc}$. 下極腎杯下端は第 4 腰椎上縁ま で下降し, 尿管仗第 4 腰椎下縁の高さで屈曲を示し, 上 部尿管内の造影剂貯溜㳉顥著である（第29図 1)。しか 乙運動像は臥位己同様に上腎杯円蓋部で開始された蠕動 収縮で中断することなく尿管へ移行し，尿管屈曲部に扢 いても中断洁認められず特に変化はない。

運動週期は $4^{1} / 8 \sim 5$ 秒で右側よりや>頻数である. 腎 孟内造影剂の消失時間仙 3 分 09 秒で正常值を示した.
血尿を認めた左側腎汢尿管屈曲部での造影剂停滞の他 には收縮運動の異常は認めなかつた。

症例 2.18才, 女子

主訴 右側腹痛

診断 右遊走腎第 $\mathbf{I}$ 度

所見

臥位

造影剤注入量 $2.0 \mathrm{cc}$. 第30図は第 120 锁よりの各部の 計測值で，レ線映画像は第32図である. 腎孟尿管像は屈 曲もなく全く正常で，蠕動収縮は腎杯円蓋部より腎盂を 経て上部尿管に移行し，その時間的推移も正常である. 運動週期は $13 \sim 16^{2} / 8$ 秒で，腎孟内造影剤は 4 分53秒で消 失した。

\section{立位}

造影剂注入量 $3.0 \mathrm{cc}$. 撮影された第 240 铛よりの計測 値をグラフに示すと第 31 図の如くで，そのレ線映画像は 第33図である。

立位をとると下腎杯下端は第 5 腰椎中央の高さまで下 降するのみでなく腎盂尿管移行部で屈曲下垂して著明な

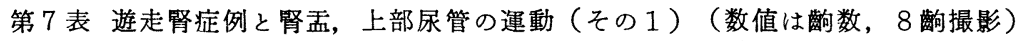

\begin{tabular}{|c|c|c|c|c|c|c|c|c|c|c|c|c|c|c|}
\hline \multirow{2}{*}{ 症例 } & \multirow{2}{*}{ 性 } & \multirow{2}{*}{ 年令 } & \multirow{2}{*}{ 主訴 } & \multirow{2}{*}{\multicolumn{2}{|c|}{ 患側 }} & \multirow{2}{*}{ 遊走度 } & \multirow{2}{*}{ 体位 } & \multicolumn{2}{|c|}{ 腎孟 } & \multicolumn{2}{|c|}{ 上部尿管 } & \multirow{2}{*}{ 週期 } & \multirow{2}{*}{$\left|\begin{array}{c}\text { 造影剤 } \\
\text { 消失間 }\end{array}\right|$} & \multirow{2}{*}{ V線像 } \\
\hline & & & & & & & & 収縮 & ·弛緩 & 収縮 & 弛緩 & & & \\
\hline \multirow{4}{*}{1} & \multirow{4}{*}{$\hat{\delta}$} & \multirow{4}{*}{48} & \multirow{4}{*}{ 血尿 } & \multirow{4}{*}{ 両 } & \multirow{2}{*}{ 右 } & \multirow{2}{*}{ III } & 臥 & 8 & 20 & 21 & 19 & 55 & $7^{\prime} 12^{\prime \prime}$ & \\
\hline & & & & & & & 立 & 10 & 12 & 27 & 10 & 54 & $6^{\prime} 04^{\prime \prime}$ & 尿管届曲 \\
\hline & & & & & \multirow{2}{*}{ 左 } & \multirow{2}{*}{ I } & 臥 & 13 & 9 & 12 & 12 & 50 & $3^{\prime} 54^{\prime \prime}$ & \\
\hline & & & & & & & 立 & 11 & 11 & 12 & 11 & 45 & $3^{\prime} 09^{\prime \prime}$ & $\overline{\text { 尿管用曲 }}$ \\
\hline \multirow{2}{*}{2} & \multirow{2}{*}{$q$} & \multirow{2}{*}{18} & \multirow{2}{*}{ 右側腹痛 } & \multirow{2}{*}{\multicolumn{2}{|c|}{ 右 }} & \multirow{2}{*}{ III } & 臥 & 12 & 14 & 14 & 14 & 118 & $4^{\prime} 53^{\prime \prime}$ & \\
\hline & & & & & & & 立 & & & 18 & 16 & 80 & $8^{\prime} 10^{\prime \prime}$ & 俯届像 \\
\hline \multirow{2}{*}{3} & \multirow{2}{*}{ 우 } & \multirow{2}{*}{40} & \multirow{2}{*}{ 右側腹痛 } & & & & 臥 & 3 & 4 & 9 & 7 & 46 & 15'以上 & 尿路拡張 \\
\hline & & & & & & III & 立 & & & 14 & 15 & 56 & $15^{\prime}$ 以上 & 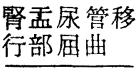 \\
\hline 4 & 우 & 33 & 右側腹痛 & & & III & 臥 & 16 & 13 & 10 & 9 & 130 & $8^{\prime} 55^{\prime \prime}$ & \\
\hline & & & & & & & 立 & 10 & 6 & 29 & 32 & 99 & $6^{\prime} 37^{\prime \prime}$ & 俯用像 \\
\hline & & & & & 右 & III & 臥 & 17 & 14 & 16 & 16 & 86 & $6^{\prime} 35^{\prime \prime}$ & \\
\hline & & & & & & & 立 & & & 24 & 21 & 67 & $9^{\prime} 53^{\prime \prime}$ & 俯凮像 \\
\hline 5 & 우 & 28 & 残尿感 & 両 & & & 臥 & 14 & 17 & 11 & 14 & 65 & $5^{\prime} 20^{\prime \prime}$ & \\
\hline & & & & & 左 & II & 立 & & & 18 & 15 & 49 & $6^{\prime} 20^{\prime \prime}$ & 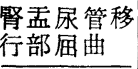 \\
\hline & & & & & & & 臥 & 21 & 11 & 18 & 20 & 104 & $12^{\prime} 50^{\prime \prime}$ & \\
\hline 6 & ? & 43 & 腰痛 & 右 & 石 & III & 立 & 18 & 10 & 19 & 18 & 98 & $15^{\prime}$ 以上 & $\begin{array}{l}\text { 堅孟烝管移 } \\
\text { 部屈曲 }\end{array}$ \\
\hline & & & & & 左 & III & 臥 & 16 & 20 & 20 & 23 & 121 & $10^{\prime} 51^{\prime \prime}$ & \\
\hline & & & & & & & 立 & 14 & 19 & 17 & 20 & 101 & $11^{\prime} 46^{\prime \prime}$ & \\
\hline 7 & 우 & 23 & |右側腹痛| & & & $\mathrm{I}^{\prime}$ & 臥 & 11 & 10 & 13 & 12 & 108 & $3^{\prime} 20^{\prime \prime}$ & \\
\hline & & & & & & & 立 & 15 & 18 & 14 & 16 & 67 & $1^{\prime} 55^{\prime \prime}$ & \\
\hline
\end{tabular}


第 7 表 遊走腎症例と腎监，上部尿管の運動（その 2)

\begin{tabular}{|c|c|c|c|c|c|c|c|c|c|c|c|c|c|c|}
\hline \multirow{2}{*}{ 症例 } & \multirow{2}{*}{ 性 } & \multirow{2}{*}{ 年令 } & \multirow{2}{*}{ 主訴 } & \multirow{2}{*}{\multicolumn{2}{|c|}{ 患側 }} & \multirow{2}{*}{ 遊走度 } & \multirow{2}{*}{ 体位 } & \multicolumn{2}{|c|}{ 腎孟 } & \multicolumn{2}{|c|}{ 上部尿管 } & \multirow{2}{*}{ 週期 } & \multirow{2}{*}{$\mid \begin{array}{c}\text { 造影剤 } \\
\text { 消失間 }\end{array}$} & \multirow{2}{*}{ レ線像 } \\
\hline & & & & & & & & 収縮 & 弛緩 & 収縮 & 弛緩 & & & \\
\hline \multirow{2}{*}{8} & \multirow{2}{*}{ q } & \multirow{2}{*}{23} & \multirow{2}{*}{ 右側腹痛 } & \multirow{2}{*}{\multicolumn{2}{|c|}{ 右 }} & \multirow{2}{*}{ II } & 臥 & 29 & 30 & 26 & 29 & 86 & $7^{\prime} 11^{\prime \prime}$ & \\
\hline & & & & & & & 立 & 13 & 10 & 19 & 15 & 53 & $6^{\prime} 20^{\prime \prime}$ & 尿管届Hil \\
\hline \multirow[t]{2}{*}{9} & \multirow{2}{*}{ 우 } & \multirow{2}{*}{33} & \multirow{2}{*}{ 下腹痛 } & \multirow{2}{*}{\multicolumn{2}{|c|}{ 右 }} & \multirow{2}{*}{ I } & 臥 & 24 & 20 & 34 & 30 & 137 & $8^{\prime} 23^{\prime \prime}$ & \\
\hline & & & & & & & 立 & 17 & 27 & 26 & 29 & 78 & $4^{\prime} 18^{\prime \prime}$ & \\
\hline \multirow[t]{2}{*}{10} & \multirow{2}{*}{ q } & \multirow{2}{*}{20} & \multirow{2}{*}{ 血尿 } & \multirow{2}{*}{\multicolumn{2}{|c|}{ 左 }} & \multirow[t]{2}{*}{ I } & 臥 & 27 & 29 & 31 & 22 & 136 & $9^{\prime} 41^{\prime \prime}$ & \\
\hline & & & & & & & 立 & 22 & 13 & 21 & 12 & 143 & $8^{\prime} 50^{\prime \prime}$ & \\
\hline & & & & & & & 臥 & 26 & 35 & 13 & 28 & 71 & $7^{\prime} 36^{\prime \prime}$ & \\
\hline 11 & $\hat{o}$ & 28 & 右腰痛 & 両 & 石 & III & 立 & 14 & 19 & 14 & 26 & 44 & $8^{\prime} 18^{\prime \prime}$ & 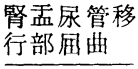 \\
\hline & & & & & 左 & II & 臥 & 16 & 10 & 21 & 22 & 52 & $6^{\prime} 32^{\prime \prime}$ & \\
\hline & & & & & & & 立 & 14 & 18 & 20 & 26 & 42 & $3^{\prime} 10^{\prime \prime}$ & \\
\hline & & & & & & & 臥 & 16 & 24 & 30 & 26 & 102 & $6^{\prime} 49^{\prime \prime}$ & 腎孟拡張 \\
\hline 12 & 우 & 31 & 腰痛 & 両 & 石 & II & 立 & 33 & 38 & 36 & 39 & 136 & $9^{\prime} 10^{\prime \prime}$ & 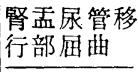 \\
\hline & & & & & 左 & II & 臥 & 22 & 42 & 34 & 26 & 98 & $7^{\prime} 14^{\prime \prime}$ & \\
\hline & & & & & & & 立 & 26 & 37 & 40 & 23 & 133 & $5^{\prime} 58^{\prime \prime}$ & \\
\hline & & & & & & & 臥 & 26 & 31 & 24 & 23 & 134 & $8^{\prime} 53^{\prime \prime}$ & \\
\hline 13 & 今 & 20 & 下腹痛 & 両 & 石 & $\mathbb{1 1}$ & 立 & & & 29 & 27 & 146 & $15^{\prime}$ 以上 & $\begin{array}{l}\text { 㹂孟尿管移 } \\
\text { 部届曲 }\end{array}$ \\
\hline & & & & & 左 & I & 臥 & 24 & 27 & 22 & 12 & 132 & $5^{\prime} 47^{\prime \prime}$ & \\
\hline & & & & & & & 立 & 28 & 31 & 18 & 9 & 109 & $7^{\prime} 39^{\prime \prime}$ & 尿管周日肖 \\
\hline & & & & & & & 臥 & 27 & 25 & 21 & 25 & 86 & $6^{\prime} 24^{\prime \prime}$ & \\
\hline 14 & $\hat{o}$ & 43 & 両側腹痛 & 両 & 石 & III & 立 & 35 & 30 & 22 & 19 & 91 & $9^{\prime} 18^{\prime \prime}$ & $\begin{array}{l}\text { 堅孟尿管移部届曲 } \\
\text { 部 }\end{array}$ \\
\hline & & & & & & $\pi$ & 臥 & 21 & 20 & 23 & 16 & 102 & $7^{\prime} 51^{\prime \prime}$ & \\
\hline & & & & & 石 & II & 立 & 24 & 20 & 28 & 15 & 84 & $8^{\prime} 04^{\prime \prime}$ & 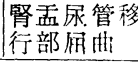 \\
\hline
\end{tabular}

第 8 表 立位時腎孟収縮運動の変化

\begin{tabular}{|c|c|c|c|c|c|}
\hline \multirow{2}{*}{ 腎昷運動時間 } & \multirow{2}{*}{ 例数 } & \multicolumn{3}{|c|}{ 腎遊走度 } & \multirow{2}{*}{ 百分率 } \\
\hline & & I & II & III & \\
\hline 収縮運動消失 & 5 & & 2 & 3 & $23.81 \%$ \\
\hline 収縮期短縮 & 9 & 3 & 3 & 3 & $42.85 \%$ \\
\hline 収縮期延長 & 7 & 2 & 3 & 2 & $33.33 \%$ \\
\hline 弛緩期短縮 & 8 & 1 & 3 & 4 & $38.09 \%$ \\
\hline 弛緩期延長 & 7 & 4 & 2 & 1 & $33.33 \%$ \\
\hline 弛緩期不変 & 1 & & 1 & & $4.76 \%$ \\
\hline
\end{tabular}

俯屈像を呈している，腎杯，腎孟は造影剂の販溜によつ て拡張しその収縮弛緩運動は判然としない. 第31図の計 測值の変化を見ても腎杯，腎肝は緊張の增減を繰返えす のみで収縮期，弛緩期を分ける事は困難である.

腎杯，腎孟の収縮運動は立位時に消失したが，屈曲し た腎盂尿管移行部以下の上部尿管には終始週期的収縮運
第 9 表 立位時上部尿管の収縮運動の変化

\begin{tabular}{|c|c|c|c|c|c|}
\hline \multirow{2}{*}{$\begin{array}{l}\text { 上部尿管運動 } \\
\text { 烸間 }\end{array}$} & \multirow{2}{*}{ 例数 } & \multicolumn{3}{|c|}{ 腎遊走腎 } & \multirow{2}{*}{ 百分率 } \\
\hline & & I & $\mathbb{I}$ & III & \\
\hline 収縮期短縮 & 7 & 3 & 3 & 1 & $33.33 \%$ \\
\hline 収縮期延長 & 14 & 2 & 5 & 7 & $66.66 \%$ \\
\hline 池緩期短縮 & 12 & 4 & 4 & 4 & $57.14 \%$ \\
\hline 吔緩期延長 & 9 & 1 & 4 & 4 & $42.85 \%$ \\
\hline
\end{tabular}

動が認められて，少量の尿管内容が膀胱側へ送られるの が認められた。

腎孟内造影剂が次第に減少した 4 分後に恪各腎杯で略 «同時に緊張の增加が起り，わずかに腎杯胿を狭め，乙 れに続いて腎孟の軽微の収縮運動があり, 腎孟内容が座 曲した腎孟尿管移行部を通つて上部尿管に移動するのが 認められた。

臥位と立位で上述の様に収縮運動が変化するの社立位 
時の腎下降によつて腎杯, 腎盘は尿管起始部より下方に 転移する上に腎孟尿管移行部の屈曲による高度の通過障 害が加わり腎孟内圧の上昇のため収縮力の減弱を来たす ものと考える.

腎固定術後の排尿運動像

腎固定術施行後27日で撮影したレ線映画像が第34四で ある.術前の造影剂注入量と同じく臥位 $2.0 \mathrm{cc}$, 立位 3.0 ccの逆行性腎盂像で観察した.

臥位に损ける収縮運動㹥術前の臥位時と全く同じで正 常運動である.

立位でも下極腎杯の下端认第 3 腰椎上縁の高さに固定 されて腎の転移, 尿路屈曲は認められず, 呼吸運動によ る上下移動も殆ん，ぞ認めない．尿管カテーテル拔去 5 秒 後（第34図 2 ）収縮住上腎杯兮ら開始されて蠕動的に腎 孟へ移行し，円滑に上部尿管の収縮となつている（第34 図 3，4)．立位では臥位に比して収縮運動は緩徐であ るが，30秒後に注第 34 図 5 の如く腎孟内容㹥急速に排泄 されて, 第 2 回の蠕動収縮でカテーテル抜去 38 秒後には 腎孟内造影剤は全く排泄された。

症例 3.40 才, 女子

主訴 右側腹痛

診断 右遊走腎第正度，水腎症

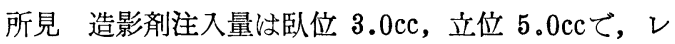
線咉画像は第35図である.

臥位，レ線像で腎杯，腎孟，上部尿管は水腎状で高度 の拡張を示しているが尿路屈曲は認められない。

腎杯は搪張したま つで収縮運動は消失しており, 腎典 にて軽微の収縮運動が行われ, 上部尿管へ移行するのが 認められたが，その収縮力は甚だ弱い。腎孟収縮時には 腎孟腎杯逆流現象はなく，尿管カテーテルを拔去して15 分経過するも腎孟像の陰影はわずかに薄くなつた程度で 殆んど変化せず排泄能力は著しく低下している（第35図 1, 2).

立位（第35図 3 )

下極腎杯の下端恣第 5 腰椎中央の高さまで下降し, 腎 孟尿管移行部々上部尿管の 2 力所で強い屆曲を示し, 腎 孟は一層水腎状に拡張している.

収縮運動を見ると，臥位でわずかながら認められた腎

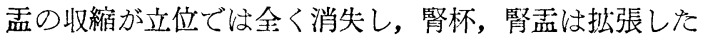
ま〉で収縮運動は認められない，甚だ特異な所見は，立 位腎盂像で造影剤が腎孟下部腎杯に貯溜して鏡面像を形 成し, 下部から造影剂の貯溜層, 混合層, 透明層の 3 つ を識別出来る映像が得られた事である。これは腎杯，腎
孟の収縮運動が消失したために，これまでに屡从述べた 腎㙉腎杯逆流現象も行われず腎盂内容の移動がなく, 完 全なアトニー状を示すものて，撮影前から多量の尿が拡。 張した腎杯，腎杯に停滞していた事を示すものである.

腎杯，腎盂では収縮運動が消失したけれごも，屈曲し た腎盂尿管移行部以下の尿管には週期的蠕動収縮が下方 の尿管屈曲部でも中断することなく膀胱側へ移行するの が認められた。しかし尿管の弛緩時には腎盂より流下し た造影剂は上部尿管の屈曲部上り上部に一時停溜し, 尿 管屈曲部より下方の尿管像は出現せず，更に腎盂からの 流下が増加すると造影剂は屈曲部を通過して全尿管像を 現わすに至り，尿管の通過障碍は顕著である.

尿管カテーテル抜去15分後も下部腎杯内に多量の造影 剤が残存するのを見た。

腎固定術後の排尿運動像

第36図は腎固定術後33日で撮影したレ線咉画像であ る.

臥位（第36図 1，2，3）

腎孟尿管像快未だ水腫拡張を認めるが, 上腎杯に術前 認められなかつた收縮が軽度ながら出現している（第36、 図 1)。腎孟尿管の収縮運動は明膫に認められるょうに なり，特に拡張した尿管の運動は術前に比して可成り強 力に行われ尿管腔を狭ばめている。週期的蠕動收縮が上 腎杯円蓋部より腎㙉，尿管へと連続移行するのが認めら， れるに至つたが，下腎杯の收縮は未だ回復していない。 立位（第36図 4,5 )

立位でも下極腎杯の下端经第 II 腰椎下縁の高さにあり 正常位置に固定されて尿管像は直線状で術前の尿管屈曲 は全く認めない。

$5.0 \mathrm{cc}$ の造影剤注入では上腎杯円蓋部 まで造影出来 ず，尿管カテーテル抜去と同時に造影剂は腎盂下部に貯 溜し，未だ尚鏡面像を形成しているが，弛緩せる尿管へ の造影剤の流下は急速に行われ，尿管カテーテル抜去10 秒後には第 36 図 5 で見るよう腎搵収縮と同時に腎㙉内 造影剤结急激と排出されて僅に下部腎杯腔内に残留して いるのみである。

腎固定術後の腎盂内造影剤の消失時間 卧臥位 13 分 21 秒, 立位 3 分 24 秒となり, 立位時汇注著しく短縮され, 腎固定術によつて上部尿路の排尿運動と腎孟内容の排泄 に極めてよい結果を得た。

\section{II 総括及び考按}

遊走腎と診断された 14 例（両側 7 , 右側 6 , 左側 1 例), 21患側について撮影したレ線映画像から腎孟，上部 
第32図症例 2 , 臥位

1. 第10莗

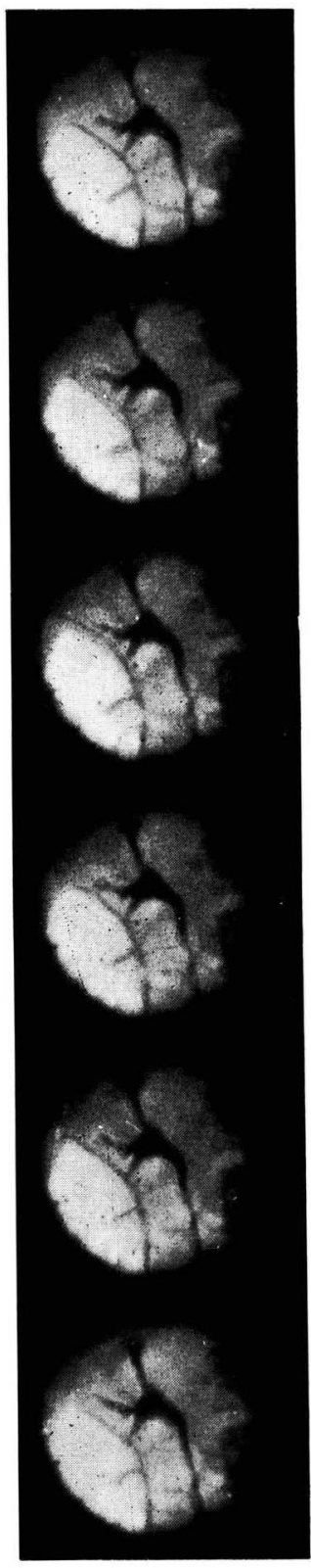

2. 第35齫

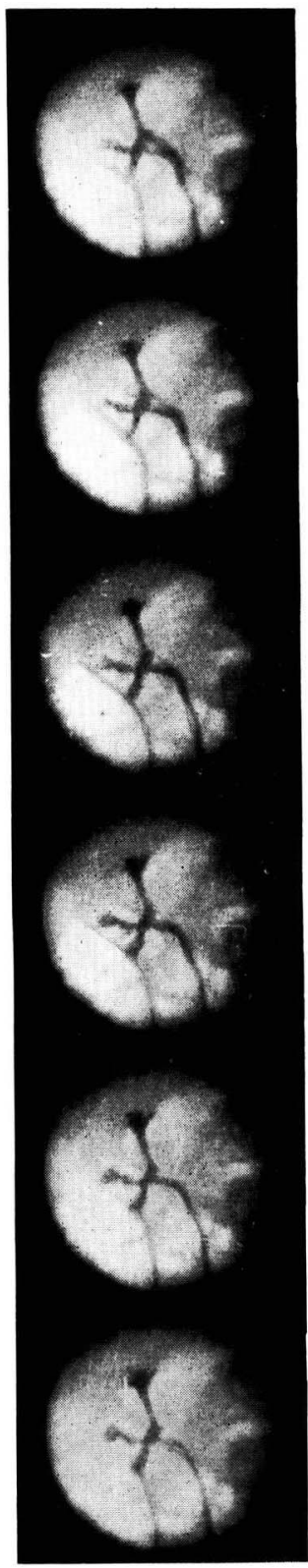

3. 第52齙

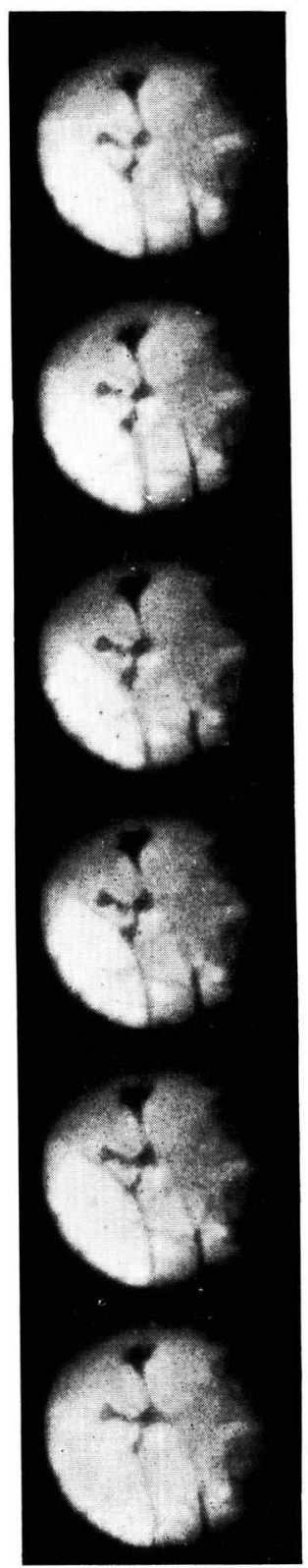

4. 第60萄

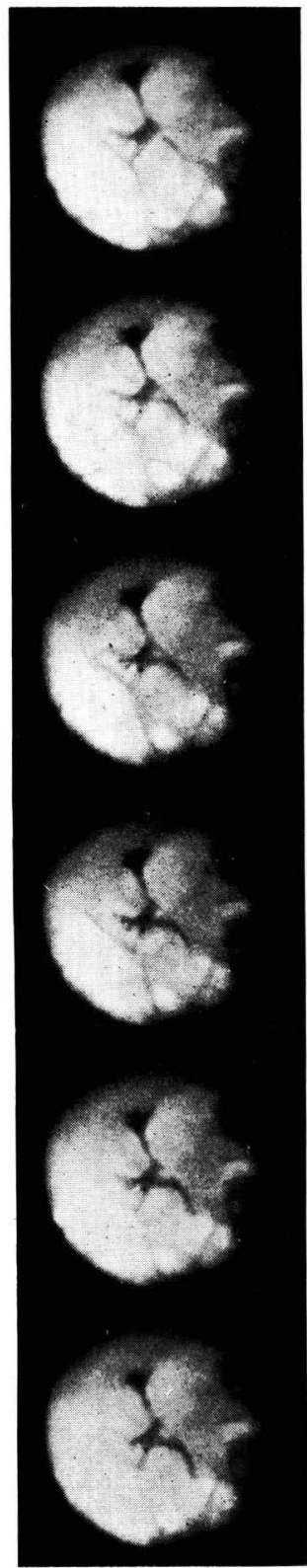

1.上, 下腎杯収縮

2. 3. 腎盎より尿管への蠕動収縮を示す。各腎杯系への逆流現象著明

4. 尿管弛緩期, 各腎杯縮小 
第33図症例 2 , 立位

1. 第 40 䶗

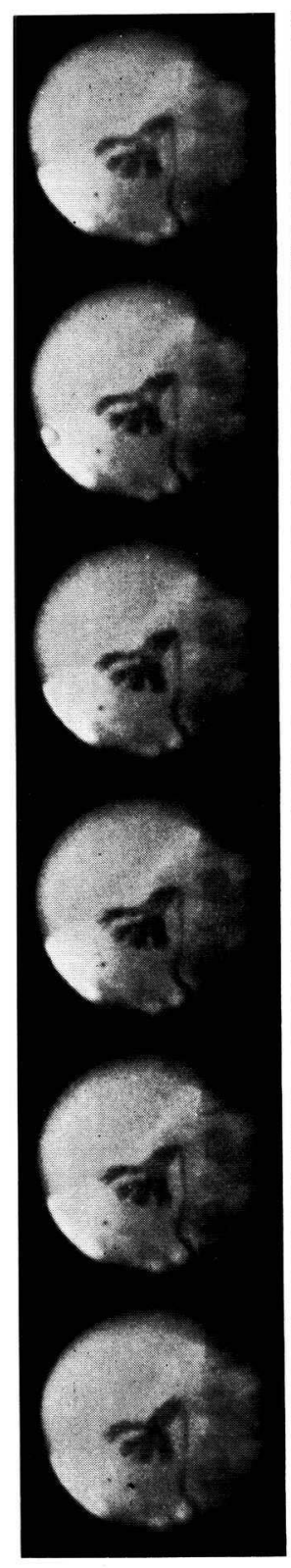

2. 第48踤

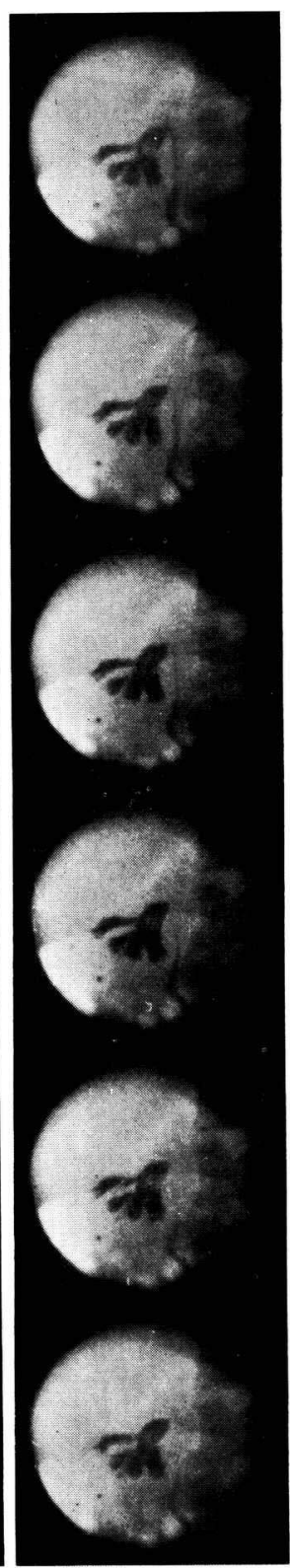

4. 第60萄

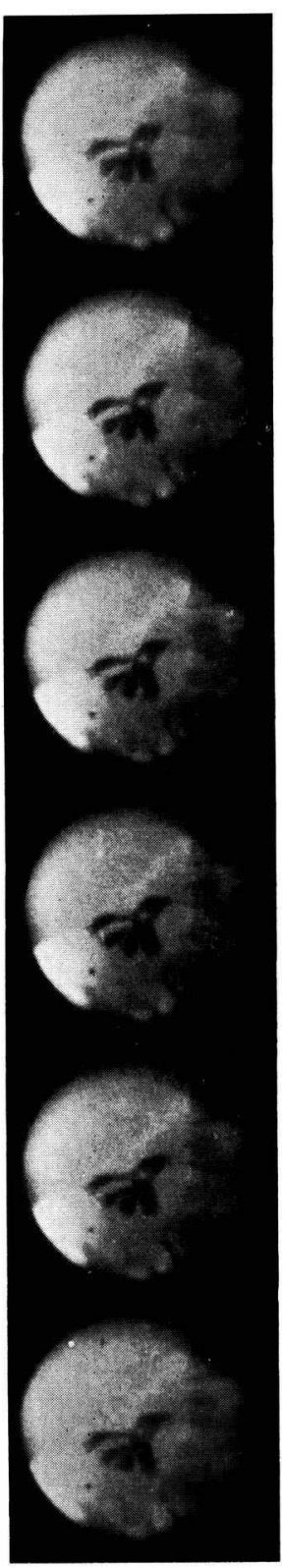

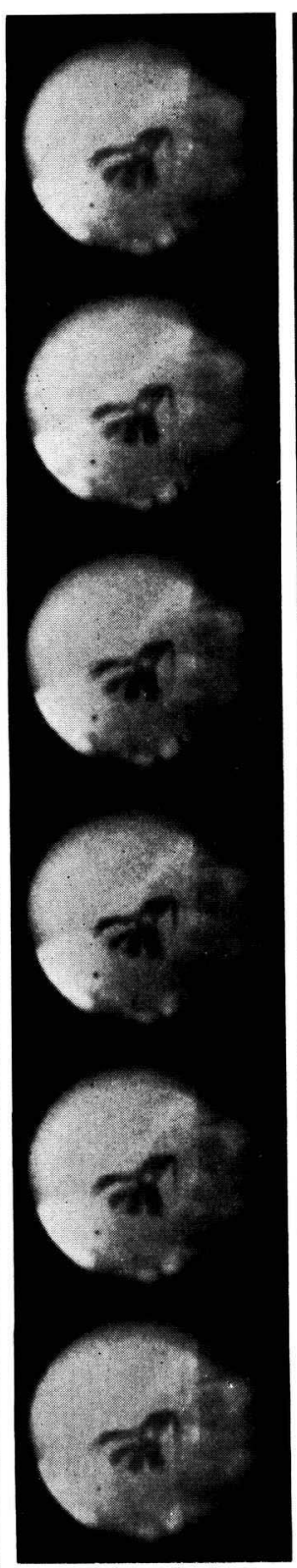

5. 第70䶖

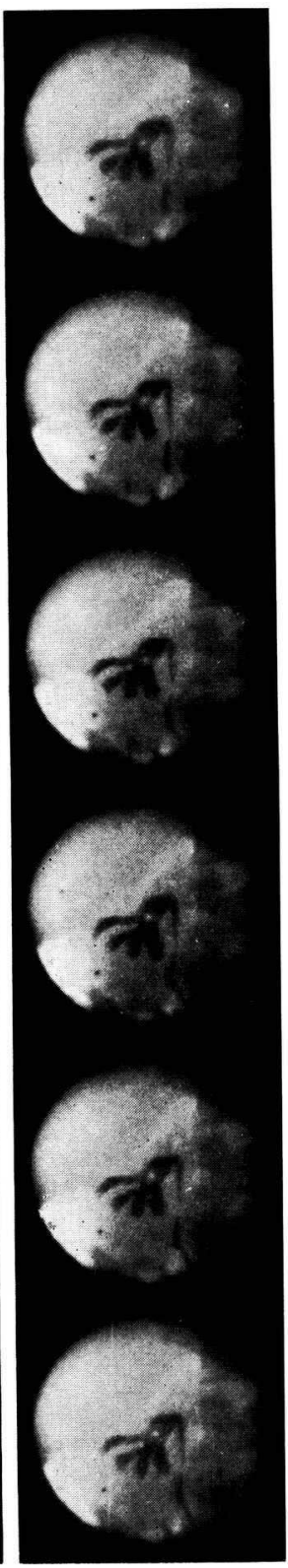

立位時の俯圧像と腎孟の蠕動収縮の消失を示す。 尿管の蠕動収縮は認められる. 
第34図 症例 2, 腎固定術後, 立位

\section{1. 逆注直後}

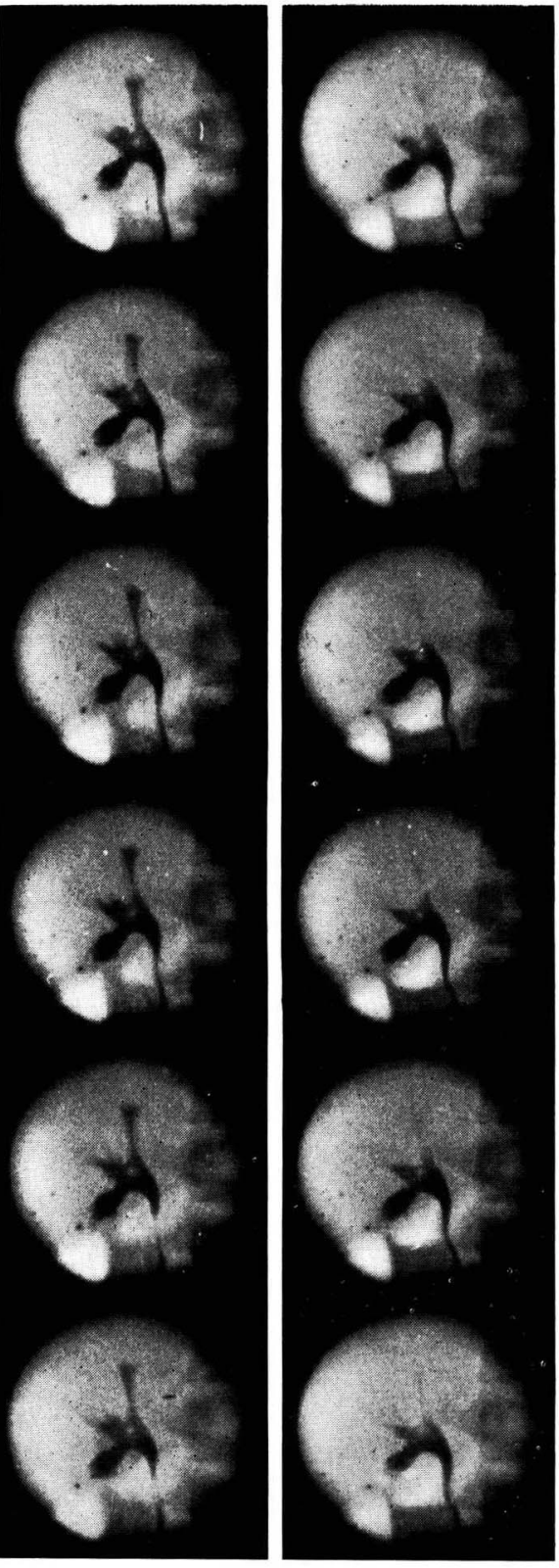

2. 第30齛

3. 第 45 齣

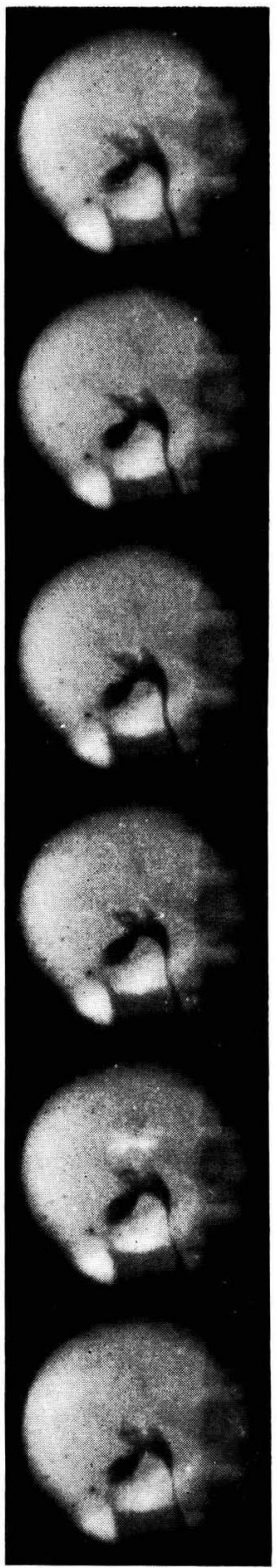

5. 第 160 鲾

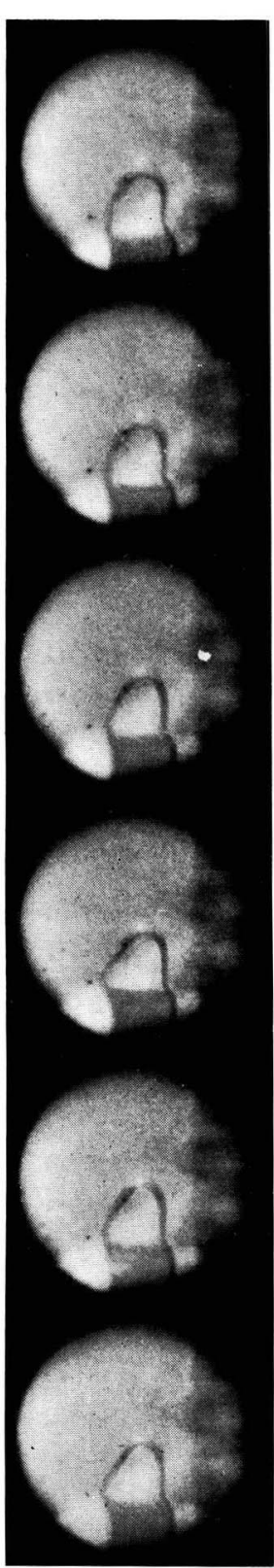

2. 上腎杯収縮

3. 4. 腎盂及び尿管の蠕動収縮を示す，

5. 20 秒後の腎㙉像，急速な造影剂排出を示す.

4. 第60踊

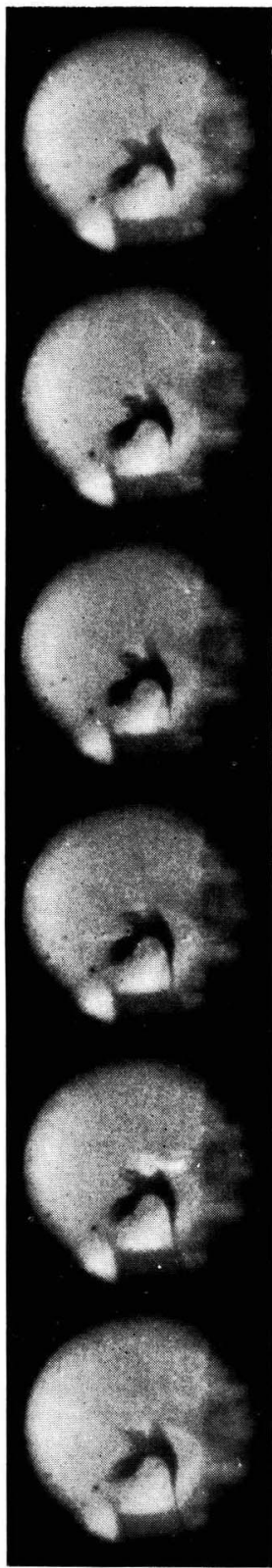


第35図症例 3

2.
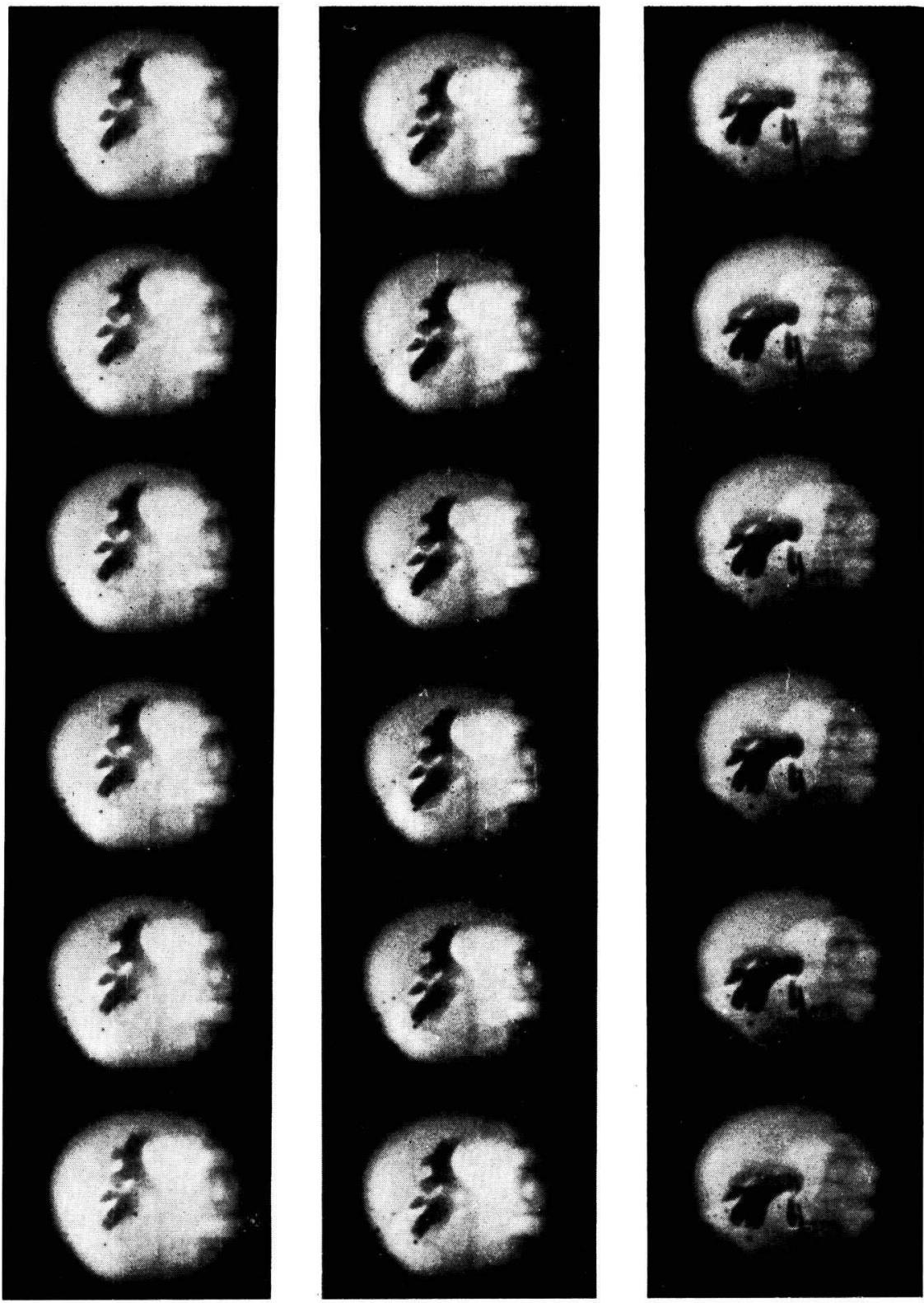

1. 及び2. 臥位腎孟像，水腎を合併し腎孟尿管運動隇弱

3. 立位腎孟像, 腎孟尿管移行部及び上部尿管㐿曲著明, 腎孟下部鏡面像形成 
第36図 症例 3 ，腎固定術後

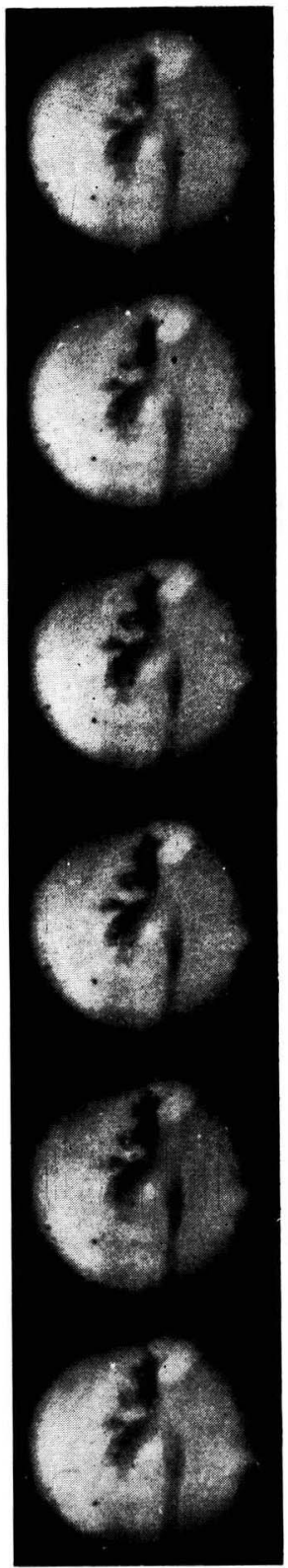

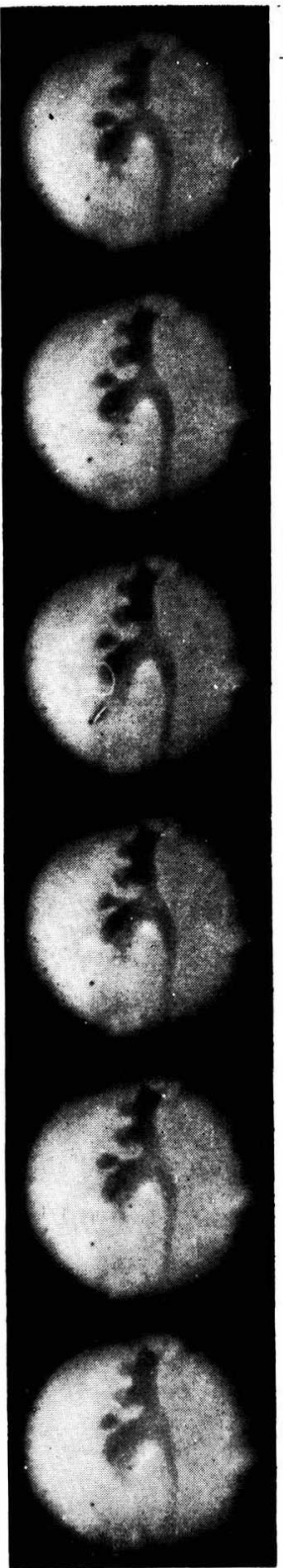

3

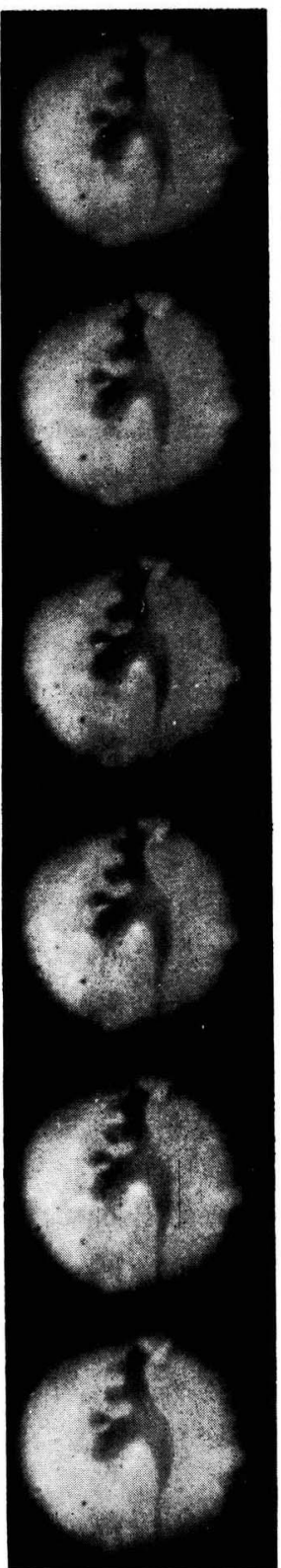

4
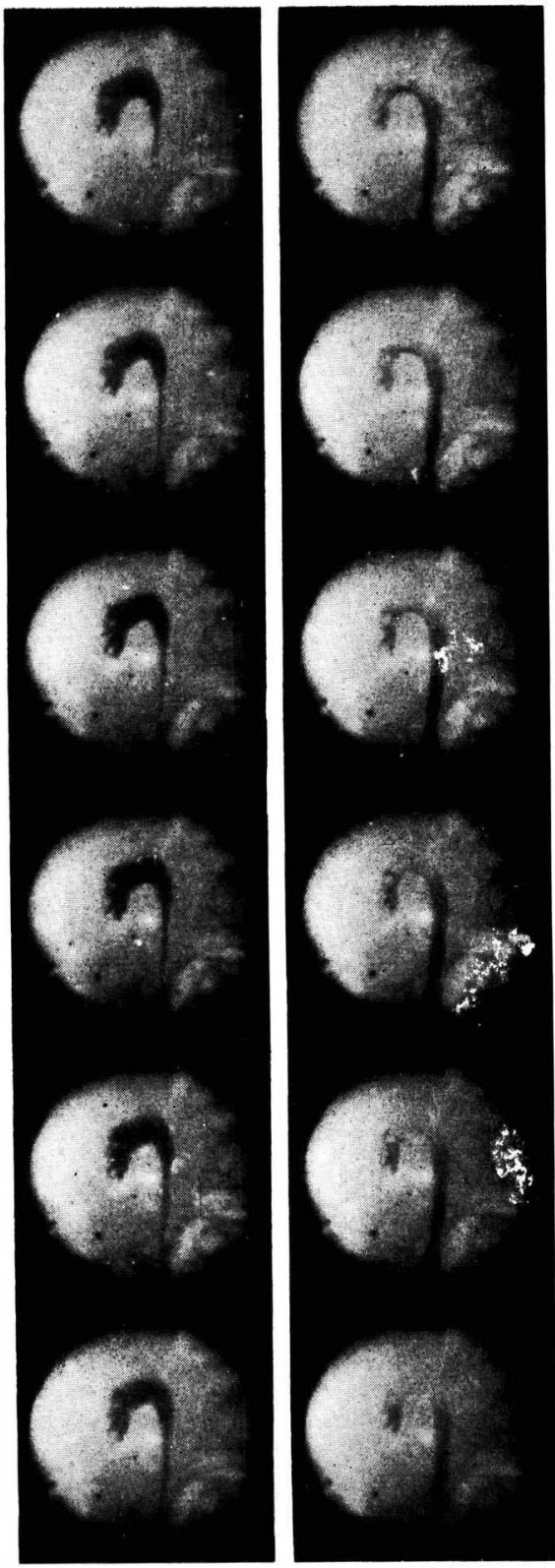

1. 2. 及び 3. 臥位堅孟像 1 は上腎杯， 2 腎孟， 3 尿管の収縮運動明瞭となる.

4. 及び 5 . 立位腎孟像, 造影剤の急速な腎孟内消失を示す。 
第37図症例 4

1

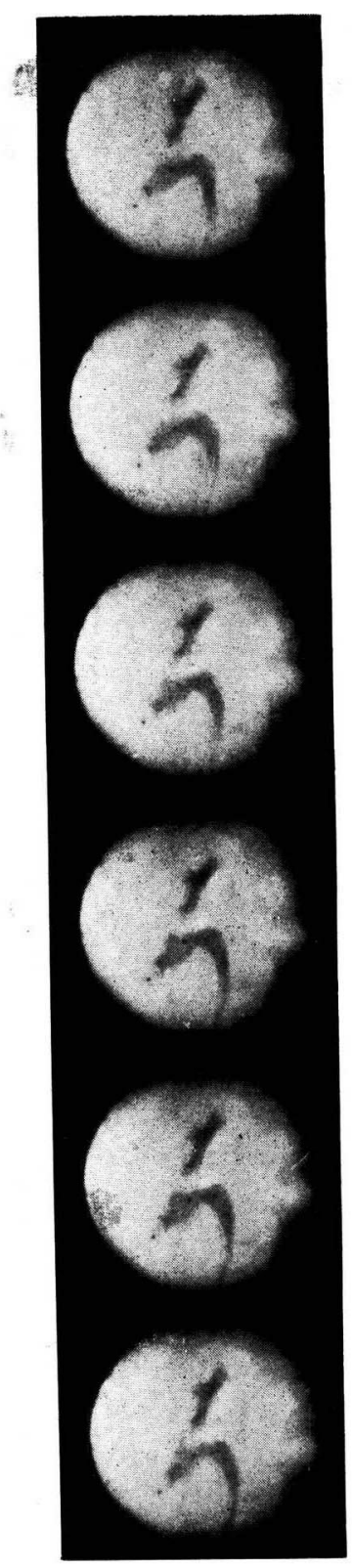

2
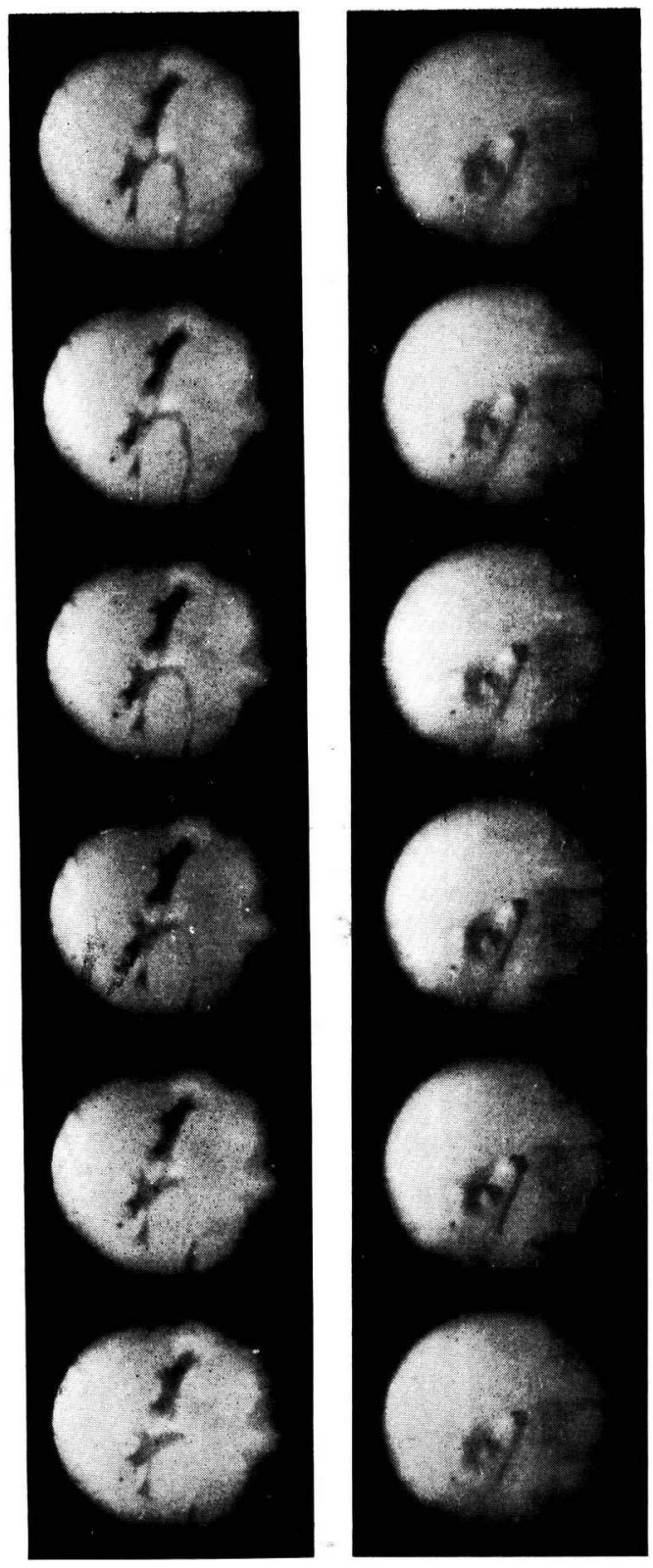

4

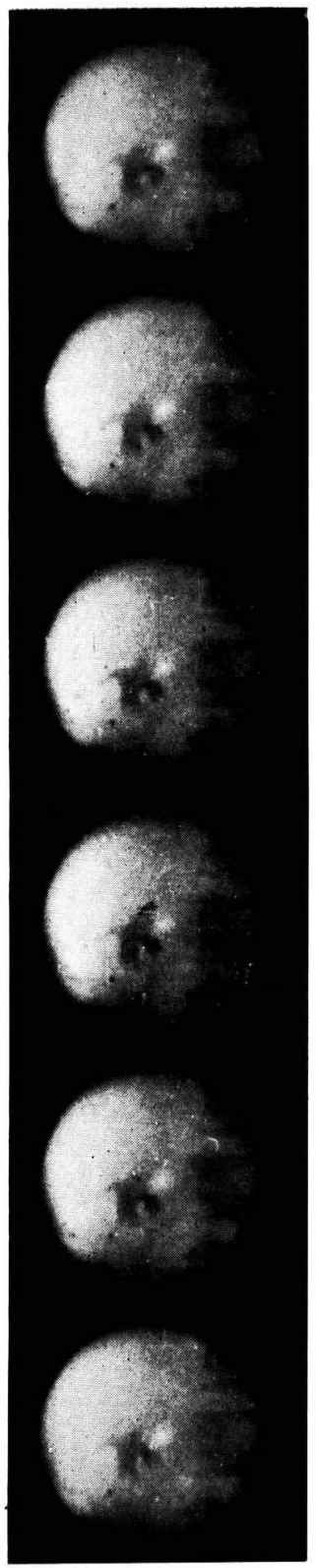

1 及び 2 臥位腎孟像

3 及び 4 立位腎孟像, 著明な俯屈像 
第38図 症例 4 , 腎固定術後
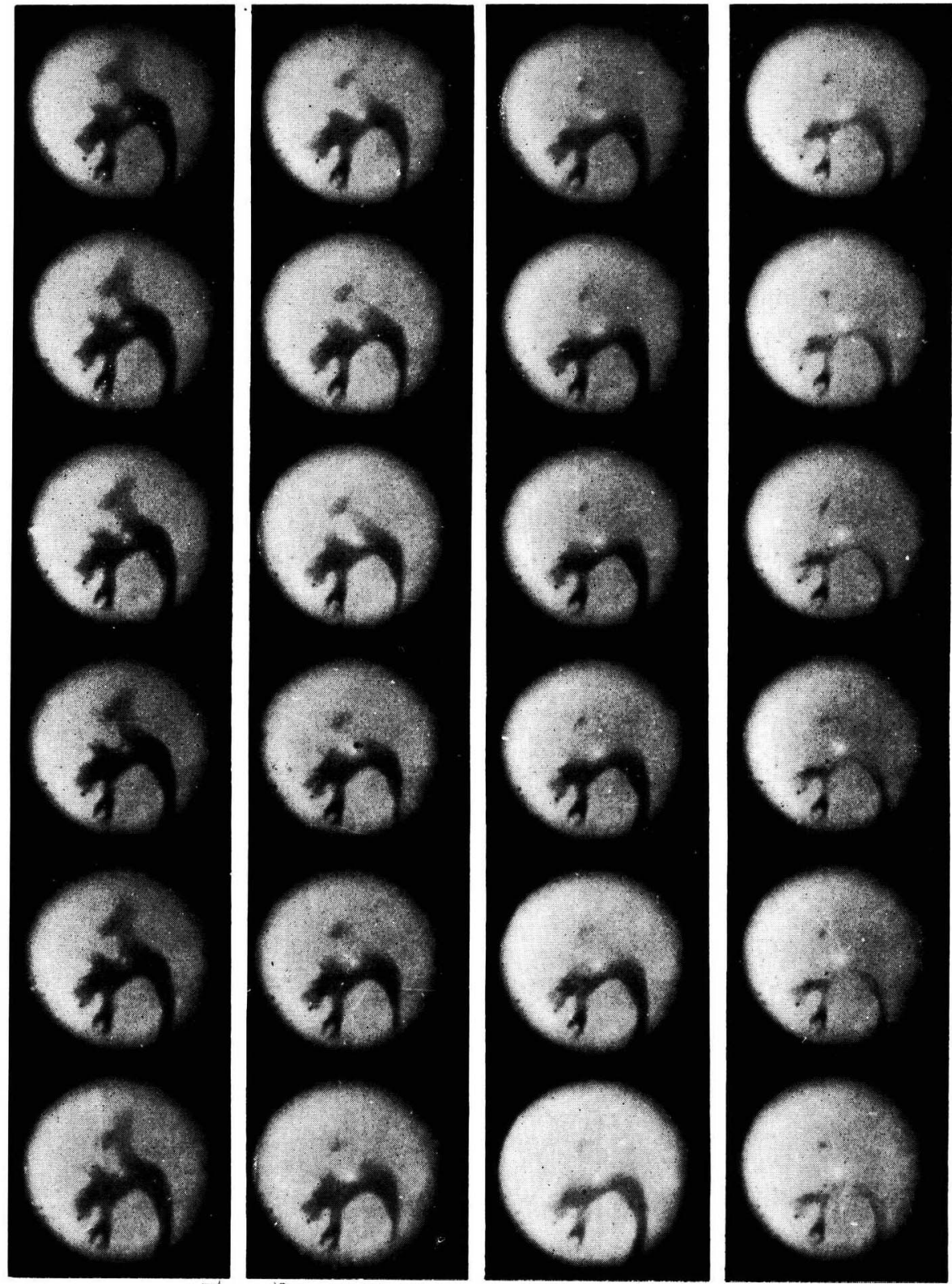

5

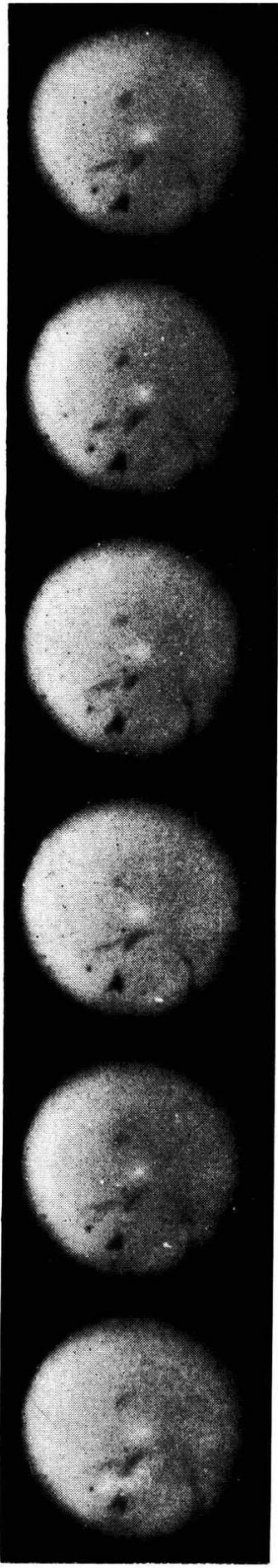

1. 逆行性注入直後,

2. 尿管カテーテル拔去直後

3. 同 5 秒後

4. 同10秒後

5. 同 30 秒後 
第39図 症例 5, 左腎臥位

1
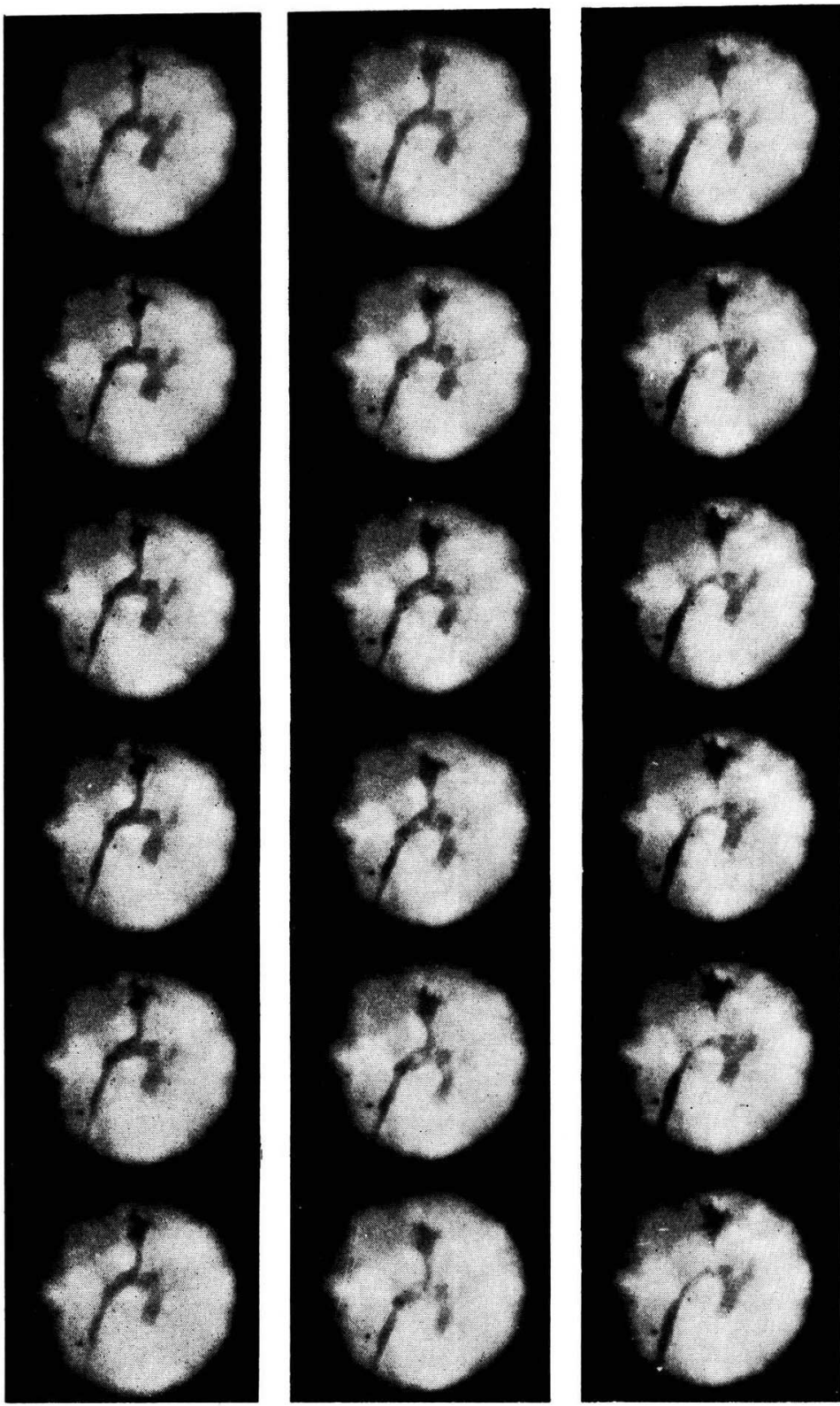

1. 上腎杯収縮期

$2 ， 3$ 下腎杯から腎盂収縮の移行．腎孟収縮極期に上腎杯への逆流著明。

4. 腎孟弛緩期と上部尿管収縮期

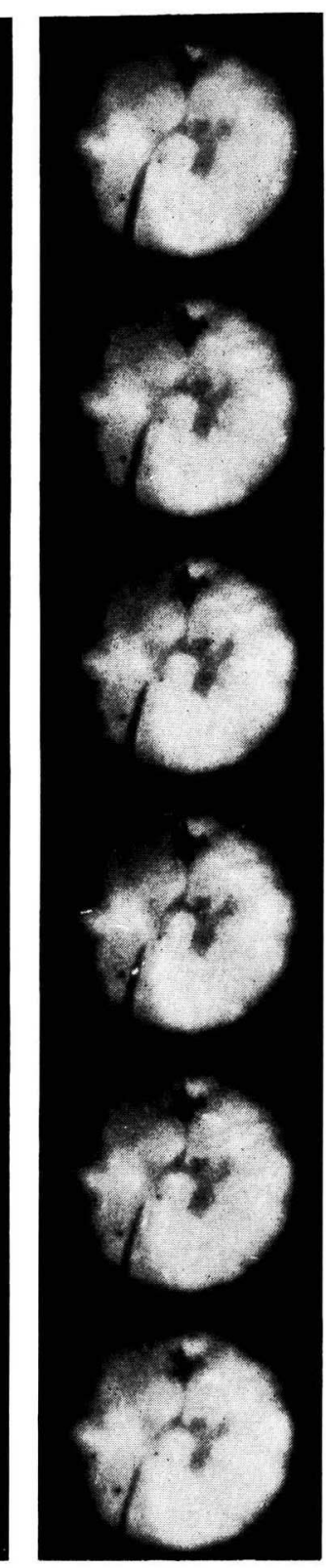

4 

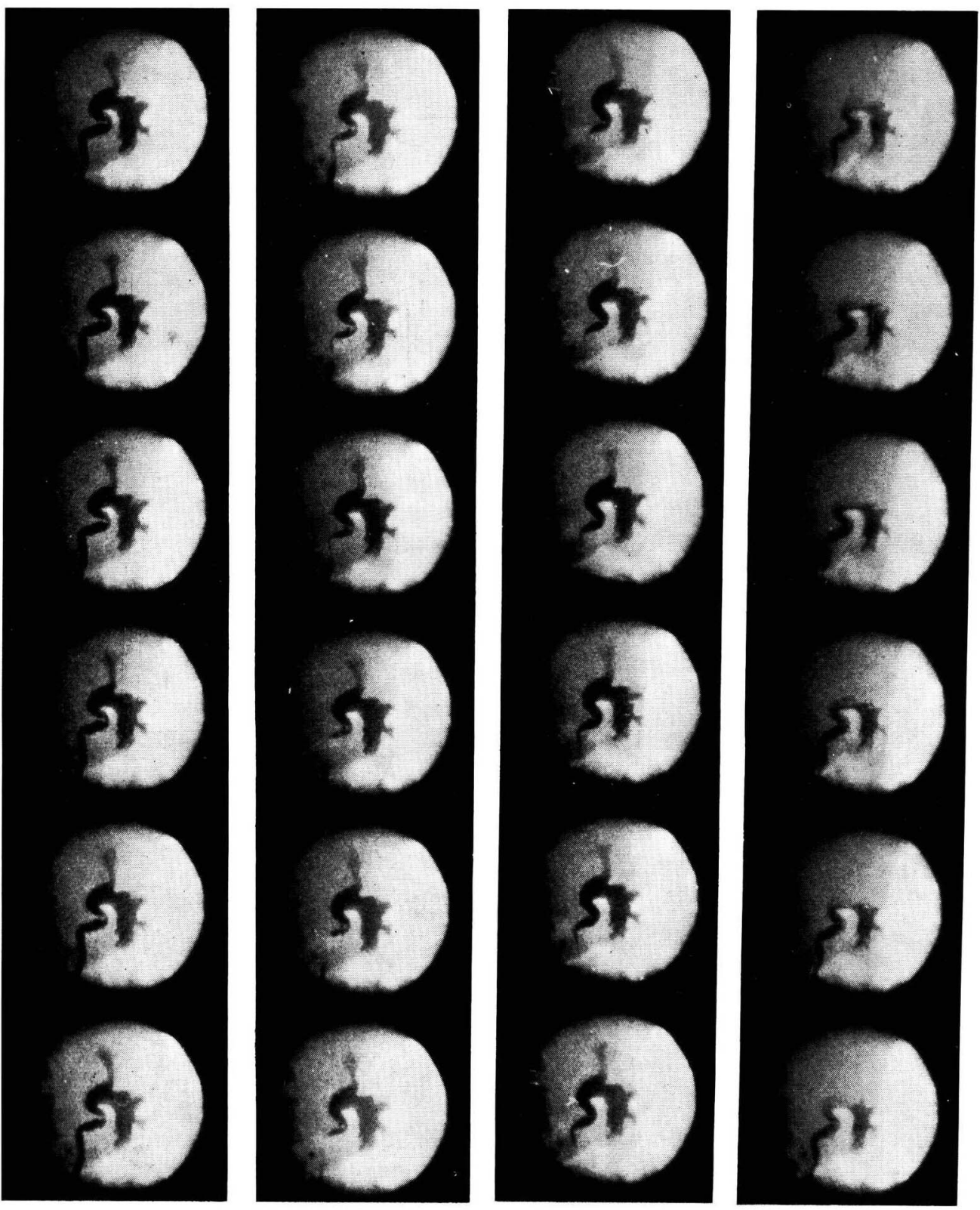

腎孟尿管移行部屈曲著明，腎孟及び下腎杯腔内の造影郕

停滞高度で収縮運動は減弱消失す，尿管の蠕動収縮の又諗められる。

4 は 2 分後の腎㙉像 
尿管の運動々腎盂内造影剂消失時間在中心に臥位及び立 位で比較すると，第 7 表，その（1）及び（2）の小う である。

腎孟，上部尿管，週期の項に示した数值は $3 \sim 7$ 回の

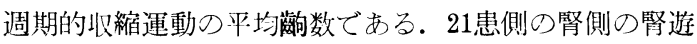
起度决，第 I 度 5 ，第 II 度 8 ，第四度 8 腎である。

臥位に於ける蠕動収縮運動の推移は第24四及で第30図 の計測值に示されたょうに正常腎上同様で，週期的に冬 皘杯系の円蓋部で開始され，腎孟老経て上:部尿管へ中断 与る事なく移行与る。.21患側中症例 $3 の 1$ 例恃卧位飞拉 いても腎杯の収縮運動就認められず腎孟，尿管の収縮も 減弱を見たが，乙の症例に以上部尿路の水腎状拆張が認 めら机た。

腎孟, 尿管の収縮弛緩運動の变化を卧位, 立位で比較 すると第 8,9 表の如くである.

立位時の腎孟に招ける收縮運動の変化で, 特に興味あ る現象快，21患側中 5 例が立位をとると腎孟の収縮弛緩 運動が消失した事である. その内症例 3 以前述の如く上 部尿路の搪張があり，卧位にても腎杯収縮 はなく，腎 孟，尿管の運動は娍弱せるものであるが，他の 4 例注第 30 図の計測值と第32図のレ線運動像や第39図で見るよう に臥位では全く正常の蠕動収縮運動を認めた症例であ る。いずれも立位時比腎䀃尿管移行部での屈曲が顕著 で, 症例 2 , 症例 5 は俯屈像を呈した症例で, 㛑遊走度が 強くなるに従って消失例も增加している。こ打高度の 腎孟尿管移行部の属曲は単なる屈曲と云うよりは，腎下 降に件つて生じた率引絞窄と表現されるもので，腎孟だ けでなく腎杯も著明な拡張を示して可成貯溜した腎孟像 こなつている。この様に屈曲部の通過障害が高度で腎孟 内貯溜が急飞增加する時は，腎㙉内压に打勝つて収縮運 動を営む事が出来ず収縮の減弱乃至消失に至るものと思 う。しかし明瞭な収縮弛緩運動老如していても腎盖壁 法波動様の緊張の增減が認められ少量の造影剤が持続的 に尿管内へ流下するのが見られるが，症例 3 屿造影剂は 鏡面像（第35図，3）を形成して腎孟下部に睁溜し全く アトニー状を示した。

立位でも腎孟の収縮運動が認められた16患側について 運動時間の変化をみると, 収縮期の運動時間の短縮せる もの 9 例, 延長せるもの 7 例で, 弛緩期の短縮せるもの 8 例, 延長 せるもの 7 例, 不変 1 例で大差涩認めない が，収縮期及び弛緩期の短縮例がや〉多い，乙れは立位 時の腎孟内貯溜によつて充分な収縮が営まれない上に急 速に弛緩拡張するため短縮すると考えられる。
正常腎立位で你腎孟内容の急速な排出によつて腎孟は 収縮期，弛緩期共に延長して緩徐な収縮運動となる傾向 があり，遊走腎症例で访收縮期及び弛緩期の運動時間の 短縮例が增加しているので，遊走腎では立位をとつても

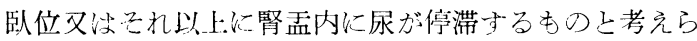
机る。

腎台の運動々腎遊走度を比較すると，収縮期の変化々 遊走度とは特別の関係は認めなかつたが，弛緩期では正 常運動である延長例が遊走度の少い症例に多く，短縮例 は遊走度に従つて増加しているので腎盎内眝溜も遊走度 に従つて高度上なる傾向を示すものであるう。

上部尿管の収縮運動は全例飞認められ，立位時腎盂の 収縮運動が消失した 5 例にも屆曲した腎孟尿管移行部以 下の上部尿管に注週期的蠕動收縮が認められた。その他 の腎盂尿管移行部で屆曲を示した症例でも腎盂の収縮運 動は蠕動的に上部尿管一移行し, 腎寻尿管移行部以下の 尿管に属曲を認めた症例でも屈曲部で中断する事なく膀 胱側へ移行した.

收縮運動は土屈曲部で中断永ず移行しても弛綏期のレ線 映画像をみると，第29図で見るょうに尿管屈曲部上り上 部に造影剤が貯溜して高度の拡張寺示場合がある。

立位時の上部尿管の運動は, 第 9 表に示したように収 縮期短縮例 7 ，同延長例 14 ，弛緩期短縮例 12 , 同延長例 9 である．正常腎では上部尿管の運動忙立位時には収縮 期は延長与るが，弛緩期泣立位時の腎孟内造影剂の急速 な排泄減少によつて尿管内充盈度が減少して短縮与る傾 向にある事を述べたが，遊走腎でも収縮期は $66.66 \%$ ， 弛緩期は57.14\%で半数以上が正常運動像寺した。

立位時の上部尿管の運動上 腎遊走度との関係を見る と, 異常運動之考えられる収縮期短縮の 7 例 $(33.33 \%)$ は遊走度の少心症例に多く認められ，正常の収縮期延長 例が遊走度に比例して增加して一見逆の結果となつてい る. 乙れ㧒遊走度の少い症例に快尿管中部の届曲が多 く, 遊走度の多いものに腎孟尿管移行部の屈曲が多数認 められ，運動の観察点を腎孟尿管移行部屈曲例ではその 直下の尿管起始部としたために，観祭点より下方に経過 障害を多く見る症例では造影剂の尿管内䝪溜を来たして 収縮期の短縮となつて現われ，柴盂尿管移行部の屈曲例 では屈曲部以下の永管充盈が少く，比較的容易に収縮が 行われて収縮離断の時間も長くなつているためである.

また弛緩期の運動で 異常を示した政長例 9 (42.85 \%）が遊走度の多い症例に增加しているのは腎侖尿管移 行部での通過障害を示すものが多くなつているので弛緩 
第10表 腎孟内造影剤消失時間

\begin{tabular}{|c|c|c|c|c|c|c|c|}
\hline \multirow{2}{*}{ 体位 } & \multirow{2}{*}{$\begin{array}{c}\text { 腎垩内造影㨈 } \\
\text { 消失時間 }\end{array}$} & \multicolumn{3}{|c|}{ 腎 遊 走 度 } & \multirow{2}{*}{ 例 数 } & \multirow{2}{*}{$\%$} & \multirow{2}{*}{ 備 考 } \\
\hline & & I & II & III & & & \\
\hline \multirow{3}{*}{ 臥位 } & 5 分末满 & 2 & & 1 & 3 & $14.3 \%$ & \multirow{2}{*}{$85.6 \%$ (正常) } \\
\hline & 10分末満 & 3 & 7 & 5 & 15 & $71.3 \%$ & \\
\hline & 10 分以上 & & 1 & 2 & 3 & $14.3 \%$ & 14.3\%（遅延） \\
\hline \multirow{3}{*}{ 立位 } & 5分未満 & 3 & 1 & & 4 & $19.0 \%$ & $19.0 \%$ (正常) \\
\hline & 10分未満 & 2 & 4 & 7 & 13 & $61.9 \%$ & \multirow{2}{*}{ 80.9\%（遅延） } \\
\hline & 10 分以上 & & 2 & 2 & 4 & $19.0 \%$ & \\
\hline
\end{tabular}

時造影剂の尿管内流下が徐々に行われて緩徐な弛緩拡張 像を示すためである。

上部尿管で観察した蠕動収縮の週期は，卧位て $5^{6} / 8$ 〜 $17^{1} / 8$ 秒, 立位で $5^{5} / 8 \sim 18^{2} / 8$ 秒に 1 回の割合で差は認め ら犸ないが，立位時 21 患側中 17 腎に週期の短縮を認めて “臥位上り頻数となつて抢り, 症例10, 症例12 (両側), 症 例14（右側）の 4 腎には週期の延長定認めた。週期延長 峢ではいずれも立位時の腎盂内造影剂の遅延した症例で あるが, 運動週期以個人差が強く, 腎遊走度及び立位時 の腎盂，尿管の収縮軍動とは直接関係は認められなかつ た.

腎孟内造影剂消失時間の観察は，正常腎と同じく70\% ウロコリンの逆行性注入量を臥位 $3.0 \mathrm{cc}$, 立位 $5.0 \mathrm{cc}$ 以 下とし，尿管カテーテル抜去直後から測定した．著者沈 卧位で10分以内，立位て 5 分以内の造影剤消失時間を正 常排泄時間として扔り，21患側の遊走腎に扮ける消失時 間を表に示すと，第10表のょうである。

遊走腎臥位では，18例85.6\%が正常時間の10分以内に 排泄され，その内 5 〜 10分を要するものが $71.3 \%$ と大部 分を占め, 3 例 $14.3 \%$ は分以上を要し, 排泄の遅延を 認めた。遅延を示した 3 腎中，1腎は臥位に拧いても水 繁様变化を見た症例 3 (第35図)で，他は腰筇边縁で尿 管像の中断を認めた症例 6 の両側である.

立位時の腎孟内造影風消失時間は，5分未満の正常例 は 4 腎 $(19.0 \%)$ に減少し，5分以上を要する遅延例は 17腎 (80.9\%) に增加して扔りその内 5 乃至10分を要し たものが13腎 (61.9\%) である.10分以上排泄の延長し たものは 4 腎 (19.0\%)で，造影剤の排泄される時間氻 ら見ても遊走腎では立位時一層腎孟内に貯溜しやすい事 を示している。

腎孟内造影剤消失時間の遅延も遊走度と平行して高率 となっている.

正常腎に执いては，立位時の消失時間は恒に臥位より
早く，急速に消失するが遊走腎症例では，21患側中卧 位，立位共 15 分後も腎盂内造影剂を認めた症例 6 を除く と，11患側 $(52.38 \%)$ 飞臥位上りも立位時腎孟内造影 剂消失時間の逯延する奇異なる所見が認められた。㹂孟 内造影剂の排泄については Thomas 等は 9 分以上造影 剤が滞留するものは排泄障害があり，遊走腎の時には多 くの場合遲延すると云つているが，著者快遊走腎症例の 腎孟内造影剂の消失時間が遅延するだけでなく, 過半数 は臥位よりも立位時の方が排泄に長時間を要し，腎孟尿 管移行部の届曲を示す功, 腎盂像の拡張が著しいもの程 その傾向が大で, 遊走度と略々平行して遅延例が增加主 る所見を得た。清水, 吉川によれば遊走腎立位時の腎孟 拡張像と腎盂尿管移行部の属曲法, 腎遊走度に平行して 増加すると述べているが, 著者の研究に上れば腎盂内貯 溜像も同様の傾向を示している.

腎固定術後の上部尿路排尿運動

上記の 14 例 21 患側の内 6 例 7 患側について腎固定術の 前後の排尿運動と排泄の変化を観察した。 その成績を総 括すれば，第11表のようである腎固定術施行後 22 乃至 43 日で術前と同様に逆行性注入量で撮影した.

腎固定術後の最も著明な変化は，固定術前立位をとる と腎孟内貯溜によつて腎杯，腎孟の収縮運動が減弱叉は 消失した症例が腎固定術後は立位時明膫な収縮運動を示 した事と，立位時の腎孟内造影剤消失時間がいずれも著 明に短縮し，排泄状況が著しく良好となつた事である.

即与症例 2 は立位時䭱下降によつて腎孟尿管移行部て 屈曲下垂し, 藷明な腎俯屈像を呈し, 腎杯, 腎盂の収縮 運動が消失した症例（第31図）で，腎固定術後怔正常の 霖動収縮運動を認め, 腎孟内造影剤の排泄は 8 分 10 秒示 ら術後38秒に短縮し極めて良好となつている.

症例 3 は水腎を合併した症例で術前臥位でも腎杯の収 縮運動胫認められず，立位時腎孟の収縮は消失して著明 な貯溜像 (第35図) を認めたが, 術後33日で水腎様変化 
第11表 腎国定術後の比較（数值は陶数）

\begin{tabular}{|c|c|c|c|c|c|c|c|c|c|c|c|c|c|c|c|c|c|}
\hline \multicolumn{2}{|r|}{ 症 } & \multicolumn{2}{|l|}{ 例 } & \multicolumn{6}{|c|}{ 術 } & \multicolumn{8}{|c|}{ 術 } \\
\hline \multirow{2}{*}{ No. } & \multirow{2}{*}{ 患側 } & \multirow{2}{*}{ 遊走度 } & \multirow{2}{*}{ 体位 } & \multicolumn{2}{|c|}{ 腎孟 } & \multicolumn{2}{|c|}{ 上部尿管 } & \multirow{2}{*}{ 運動 } & \multirow{2}{*}{ 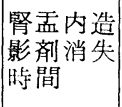 } & \multirow{2}{*}{ 術後. } & \multicolumn{2}{|c|}{ 腎孟 } & \multicolumn{2}{|c|}{ 上部尿管 } & \multirow{2}{*}{\begin{tabular}{|l|} 
\\
運動 \\
週期
\end{tabular}} & \multirow{2}{*}{$\mid \begin{array}{l}\text { 堅杰内造 } \\
\text { 影成消失 } \\
\text { 時間 }\end{array}$} & \multirow{2}{*}{ 備 考 } \\
\hline & & & & 収縮 & 他緩 & 収縮 & 地緩 & & & & 収縮 & 也緩 & 収縮 & 也緩 & & & \\
\hline \multirow[t]{2}{*}{2} & \multirow{2}{*}{ 右 } & \multirow[t]{2}{*}{ II } & 臥 & 12 & 14 & 14 & 14 & 118 & $4^{\prime} 53^{\prime \prime}$ & \multirow[t]{2}{*}{27} & 15 & 16 & 14 & 10 & 112 & $8^{\prime} 54^{\prime \prime}$ & \\
\hline & & & 立 & & & 18 & 16 & 80 & $8^{\prime} 10^{\prime \prime}$ & & 20 & 24 & 22 & 18 & $\overline{81}$ & $\overline{38^{\prime \prime}}$ & \\
\hline \multirow{3}{*}{3} & \multirow{3}{*}{ 右 } & \multirow{3}{*}{ III } & 卧 & 4 & & 9. & 7 & 46 & $15^{\prime}$ 以上 & \multirow{3}{*}{33} & 11) & $11\}$ & 17] & 16 & 781 & $12^{\prime} 21^{\prime \prime}$ & \multirow{3}{*}{$\begin{array}{l}\text { 立位時第1 } \\
\text { 回の収縮運 } \\
\text { 動で督酎像督 } \\
\text { 杯像のみ }\end{array}$} \\
\hline & & & & & & & - & & & & & & & & & & \\
\hline & & & 立 & & & 14 & 15 & 56 & $15^{\prime}$ 以上 & & & & & & 165 & $3^{\prime} 24^{\prime \prime}$ & \\
\hline \multirow[t]{2}{*}{4} & \multirow{2}{*}{ 右 } & \multirow[t]{2}{*}{ III } & 臥 & 16 & 12 & 10 & 9 & 133 & $8^{\prime} 55^{\prime \prime}$ & \multirow{2}{*}{22} & 16 & 17 & 19 & 19 & $\overline{114}$ & $9^{\prime} 47^{\prime \prime}$ & $\mu$ \\
\hline & & & 立 & 10 & 6 & 29 & 32 & 99 & $6^{\prime} 37^{\prime \prime}$ & & & & & & & $2^{\prime} 06^{\prime \prime}$ & $m$ \\
\hline 5 & 在 & III & 臥 & 17 & 14 & 16 & 16 & 86 & $6^{\prime} 35^{\prime \prime}$ & 26 & 16 & 15 & 10 & 11 & $\overline{94}$ & $3^{\prime} 41^{\prime \prime}$ & 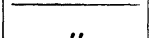 \\
\hline & & & 立 & & & 21 & 21 & $\overline{67}$ & $99^{\prime} 53 \prime^{\prime}$ & & & & & & 79 & $\overline{1^{\prime} 06^{\prime \prime}}$ & $m$ \\
\hline & 右 & III & 臥 & 21 & 11 & 18 & 20 & 104 & $12^{\prime} 50^{\prime \prime}$ & 43 & 22 & 19 & 24 & 18 & $\overline{117}$ & $3^{\prime} 57^{\prime \prime}$ & $\prime \prime$ \\
\hline 6 & & & 立 & 18 & 10 & 19 & 18 & $\mathrm{i} 01$ & $15^{\prime}$ 以上 & & & & & & 52 & $5^{\prime} 43^{\prime \prime}$ & \\
\hline & 左 & II & 臥 & 16 & 20 & 20 & 23 & $\overline{\mathrm{i} 21}$ & $10^{\prime} 51^{\prime \prime}$ & 25 & 18 & 15 & 22 & 17 & $\overline{175}$ & $4^{\prime} 12^{\prime \prime}$ & \\
\hline & & & 立 & 14 & 19 & 17 & $2 C$ & 110 & $11^{\prime} 46^{\prime \prime}$ & & 16 & $\overline{14}$ & $\overline{16}$ & 14 & $\overline{120}$ & $\overline{6^{\prime} 45^{\prime \prime}}$ & \\
\hline 7 & 大 & & 臥 & 11 & 10 & 13 & 12 & 108 & $3^{\prime} 20^{\prime \prime}$ & & 17 & 12 & 20 & 21 & 139 & $3^{\prime} 30^{\prime \prime}$ & 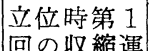 \\
\hline & & & 立 & 15 & 18 & 14 & 16 & 67 & $1^{\prime} 55^{\prime \prime}$ & & & & & & & $41^{\prime \prime}$ & 動て央血 \\
\hline
\end{tabular}

は改善されつつあり上腎杯の収縮運動は出現して蠕動的 に腎盂, 尿管の収縮に移行するの学認めた。 また立位時 には尿管カテーテル技去後 10 秒で第 1 回の蠕動収縮の開 始と同時に第36図 5 のように腎盂内造影剤は急速に排泄 されて術前立位の貯溜拡張像とは全く異つた運動像を示 ている.

即ち症例の多くは立位時尿管カテーテル抜去と同時に 造影剂は尿管内に流下し, 第 1 回の週期的蝚動収縮に上 つて腎孟内から殆んど排泄されて，極く少量が下腎杯腔 内に残留するのみであり，消失時間は臥位より著しく短 縮している. しかし症例 6 左側腎は立位の造影剤消失時 間は未だ遅延を示したが，てれを術前に比較すれば著し い短縮で腎孟内貯溜は可成り改善されている.

症例 7 以術前む上部尿路の排尿運動仗正常で, 腎血内 消失時間も正常範囲にあつて良好な排泄を認め, 遊走度

（第Ｉ度）に比して強度の腰背痛を訴えた症例で, 手術 に際し腎を下方に牽引するといつもと同様の高度の背部 放散痛を訴え, 疼痛が腎の絜引によつて生じたものと考 えられる。

臨床的症状乞の関係

清水, 吉川 ${ }^{1211}$ によれば疼痛を主訴とするものは, 109
例中68例 $(62.38 \%)$, 血尿は24例 $(22.02 \%)$ 飞認めら れ, 佐藤 ${ }^{15)}$ は 300 例中疼痛 164 例 $(54.7 \%)$, 血尿58例 (19.3\%) と報告して抢り，疼痛に次いで血尿は重要な 症状となつている. 従来疼痛の原因には腎下降に伴了腎 茎血管の血行障害, 交感神経の刺战, 尿路屈曲之通過障: 害による腎内压の上昇等が挙げられているが, 清水他 ${ }^{2121}$ は交叉性に反対側に疼痛を訴えた症例や腎被膜と腹膜と の癒着率引が疼痛の原因となつた 遊走腎症例を 報告し， た.

自験例の主訴は, 21 患例中疼痛 15 , 血尿 2 , 残尿感 2 , 自覚症状を欠くもの 2 患側である. 乙れ等の症状と 排尿運動及び造影剤の排泄状況を比較すると, 自覚症状 を訴えなかつた 2 例恃片側の主訴をもつて来院し, 夫及 第目度及び第 II 度の遊走腎を指摘された症例 1 の右腎之 症例11の左督である. 症例 1 では第27図の写真で示した ように腎下降に伴い尿管屈曲を認めながら腎杯, 腎血, 尿管へ移行する蠕動収縮の推移は第25図の計測值で見る ように異常なく, 立位時の腎孟内造影剂消失時間は稍々 遅延したが排泄状況は可成り良性である. 第11例では仗 縮運動も造影剤消失時間も正常範围にある.

疼痛を訴えた10例，15患側をみると，立位時の腎下降: 
に従つて俯屈像（症例 2 及び 4 ） 又心腎孟尿管移行部屈 曲像 (症例 $3,-6,-11$ の右腎, $-12,-13,-14$ ) を示すものが多く，腎孟拡張像があつていずれも腎盂内 造影剂消失時問の都明な遅延を認めた症例である. 立位 時に腎孟内貯溜を生じた症例々側腹痛或络腰痛を訴える ものが多い.

血尿を主訴とした症例 1 ，左腎は蠕動収縮が他の例に 比して多少頻回に行われている外には特に変化なく, 腎 孟内造影剂消失時間も臥位, 立位共に正常値を示した。 症例10は週期的蠕動収縮には変化なく, 腎盂内消失時間 は臥位，立位共に遅㒮したが，尿路屈曲も認めていな (.. Muschat ${ }^{96}$ ) 特特発性腎出血の発生機転に腎杯のス パスムスによる腎乳頭の括約を考えたが，乙の両者には 腎杯の強直性收縮の如き異常運動像は認めていない.

腎固定術後の变化を観察した 7 例は術後自覚症状は全 治すると共に, 術前立位時に腎孟内貯溜高度で腎盂収縮 運動の消失を見た症例も術後は正常の蠕動収縮を認める に至り, 全例とも腎孟内造影剤消失時間注術前に比して 著しい短縮となり，腎盂内貯溜の改善を認めた。 術前疼 痛を訴えた症例だけでなく, 残尿感を主訴として膀胼炎 症状が持続した症例 5 も立位時に著明な腎孟内貯溜の結 果腎盂の収縮運動の消失を来たしたが，腎固定術後は蠕 動収縮は明瞭となり, 術前の不快な症状は全く消失し た.

このように下垂腎を正常位置に固定すると，腎孟内貯 溜が消失して正常の蠕動收縮運動の活動を認め, 術前の 自覚症状が消失するととは, 腎下降に伴う上部尿路内容 の停滞が遊走腎の症状特に側腹痛或は腰痛を惹起せしめ る重要な因子と考える事が出来る.

症例 7 は手術時腎被膜の高度の瘾着を認めたが, ·上部 尿路のレ線映画運動像は全く正常で造影剂の排泄状況も 極めて良好であり，てのょうに排尿運動の異常又は尿路 内停滞を認めない遊走腎では疼痛の原因を他に求めるべ き事定暗示しているので, 遊走腎の診断及び治療に当り 上部尿路排尿運動の観察を強調したい. 最近はレ線像増 倍管を応用すれば，安全目簡便に鮮明な尿路透視像を観 察する事が可能となつたので今後泌尿器科領域に打ける 久くべからざる臨床診断検査法の一つとなるものと考え る.

現在当教室で行つている腎固定術々式は, 既に佐藤 ${ }^{115)}$ が報告したょうに Guyon 氏法と Kelly 氏法の変法を 併用し，腎下極後面の被膜の 2 力所に輪状に絹糸をかけ て共に腰方形筋に通して結び，更に腎下極実質に 1 本の 腸線を通して, 之も腰方形筋に固定する方法を行つてい
る.この方法によれば症例 3 （第36図）のように術後33 日では未た腎杯，腎盂の水腫桩張が残つているにも拘ら ず立位時腎孟内容は急速に排泄されて腎孟内貯溜は認め られず甚だ良好な結果を得ている。

腎孟内容の排出状況から見れば，腎固定術の施行に際 し, 立位時に尿路屈曲を生じないよう留意して固定位置 を選定すると共に，必ず腎門が内下方に向つた正常位置 に固定して答孟内貯溜を防止するょう注意すべきであ る.

\section{結 語}

I レ線像增倍管を使用した 16 ミリレ線映画撮影法に より上部尿路排尿運動を観察し, 男女 4 例の正常逆行性

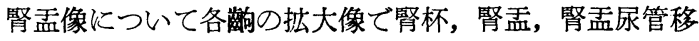
行部の横断径を一䕬有に連続計測して各部の運動時相を 比較検討した.

1）腎杯円蓋部より腎杯頝部，腎盂を経て尿管上部へ 中断する事なく連続移行する蠕動収縮運動 が認められ た. との運動は週期的に発現し, 尿路内容を膀胱側へ運 搬する。

2）週期的蝡動収縮の休止期にあつても腎杯に掞いて 々不完全ながら急速に行われる蠕動運動が認められた。 この運動访分泌された腎杯内容を弛緩している腎盕へ排 出する目的と考えられる.

3）週期的蠕動収縮の開始は，4例中臥位で 2 例，立 位時の 2 例中 1 例が各大腎杯円蓋部で 同時に開始され た. 4 例共上, 中腎杯系は円蓋部で同時に収縮開始とな つているが，その 2 例は下腎杯の久収縮開始の遅延を及 た. 下腎杯収縮開始の遅延は腎杯内逆流現象によると思 われる。

4）腎杯腎孟移行部及び腎孟尿管移行部の収縮時相を 比較した結果, 逆流を防止する括約筋的協調運動による 排尿機構は認められなかつた。

5）腎杯上り腎盂への蠕動収縮の進行時， 4 例中 2 例 に腎杯間の逆流現象を認め, 全例㭴孟腎杯逆流現象が 認められた。この逆流現象により腎杯腎㙉内圧が調節さ れて腎乳頭から集合管への逆流が防止されていると考え る.

6）排尿運動は臥位，立位共に腎杯から尿管上部へ移 行する蠕動運動である事は本質的に注変らないが, 立位 時各部の収縮期が延長する傾向がある.

7）週期的蠕動収縮の発現々呼吸運動との間に一定の 関係は認めなかつた。

8）収縮運動の週期は, 卧位, $8^{4} / 6 \sim 19^{3} / 8$ 秒, 立位 $6^{2} / 8$ 
〜 $12^{6} / 8$ 秒で立位時短縮され頻数である.

9）正常腎に於ては造影剂の腎杯腎孟内消失時間は臥 位 4 分 09 秒 $~ 8$ 分 46 秒, 立位. 1 分 20 秒 4 分 48 秒で立位 時の排泄時間は約 $1 / 2$ に短縮された。

II 男女14例21患側の遊走腎に於ける上部尿路排尿運 動を観察し次の結論を得た。

1）正常腎と同様腎杯より腎孟，尿管へ移行する週期 的蠕動収縮運動を認めるが, 立位時腎下降伴つて尿路 内停滞を生ずる時は収縮運動の減弱又は消失がある.

2）水腎様変化を半つた 1 例は卧位, 立位時共に腎杯 の収縮運動计認められなかつた。

3）立位時には21患側中 5 患側は腎孟の週期的蠕動収 樎渾動が消失した。㹂孟尿管移行部屆曲による腎孟内貯 溜の影響が大である。

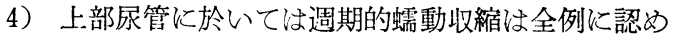
ら㣗, 過半数は正常運動である.

5）遊走腎の腎杯腎盂内造影剤消失時間は，臥位で 3 患側, $14.3 \%$ (10分以上), 立位で 17 患側 $80.9 \%$ ( 5 分以 上.) に排泄遅延を認め, 臥位時よりも立位時排泄遅延し たものは11患側 $52.38 \%$ 立位㭙腎盂内貯溜を生じ易

く, 消失時間の遅延は腎遊走度と大体平行した.

6）腎固定術後は腎孟内貯溜が消失し, 蠕動収縮運動 は正常化されて腎杯腎孟内造影剂消失時間は術前立位の 6 分 37 秒 $\sim 15$ 分以上六ら術後は 38 秒 $\sim 6$ 分 45 秒々著しく 短縮された。

後記 擱筆にあたり，御懇篭なる御指尊ならびに御校 閲を踢つた恩師清水圭三教授，三矢英輔助教授に深进な る謝意を表します。また終始御協力下さつた医局諸兄な らびに名大放射線科細江謙三助手に深謝致します。

尚本研究は文部省科学研究費に負 5 所多くこ〉に謝意 を荠します。

\section{参考文献}

1) 相羽昭：皮尿誌， $34 ， 141$, 昭8.

2) 相羽昭: 日新医学, $23,735,965,2693$, 昭9.

3）相羽昭：皮尿誌， 40,540 , 昭 11 .

4）相羽昭：日泌尿会誌, 25, 439, 昭11.

5) Alken. C.E. \& Büshner. H.K.: Z. Urol., 46, $801,1953$.

6) Alskne, J.: Folia urol., 1,338, 1907.

7) Andler, R.: Z. Urol. Chir., 17, 298, 1925.

8）浅井順：日泌尿会誌，48,789, 昭32.

9）浅井順，三宅弘治：日不妊会誌，4,132, 昭 34 .

10) Baker, R. \& Huffer. J.: Am. J. Physiol., 174, 381, 1953.

11) Baker, R. \& Huffer, J.: J. Urol., 70, 874,
1953.

12) Beauford, F.H. \& Pocher, P.: ref. Z. Urol. Chir., 24, 357, 1928.

13) Benjamin, J.A. et al.: J. Urol., 75, 25, 1956.

14) Blatt, P.: Z. Urol. Chir., 25, 148, 1928.

15) Bodner, H. et al.: J. Urol., 79, 356, 1958.

16) Boeminghaus, H.: Z. Chir., 179, 129, 1923.

17) Boeminghaus, H.: Z. Urol. Chir., 14, 71, 1923.

18) Boeminghaus, H.: Arch. Klin. Chir., 171, 109, 1932.

19) Boeminghaus, H.: Zentralbl. ges. Chir., 59, 852, 1932.

20) Bors, E. \& Blinn, K.G.: J. Urol., 74, 322, 1955.

21) Brosig, W.: Z. Urol., 46, 456, 1953.

22) Butcher, H.R. \& Sleator, W.: J. Clin. Investig., 33, 921, 1954.

23) Butcher, H.R. \& Sleator, W.: J. Urol., 73, 970, 1955.

24) Bulcher, H.R. \& Sleator, W.: J. Urol., 75, 650, 1956.

25) Catel, W. \& Garsche R.: Fortschr. Röntgenstr., 86, 66, 1957.

26) Coltmann, J.W.: Radiology, 51, 359, 1948.

27) Corey, E.L. et al.: J. Urol., 75, 244, 1956.

28) Cross, W.W.: J. Urol., 16, 37, 1926.

29) Davis, D.M.: J. Urol., 22, 339, 1929.

30) Davis, D.M.: Ann. Surg., 140, 839, 1954.

31) Decastro, J.M.: Am. J. Roentgenol., 57, 103, 1947.

32) Disse, J.: Zit. Haebler, Z. Urol., 16, 145, 1922.

33) Engelmann, T.W.: Arch. ges. Physiol., 2, 243, 1.869.

34) Engelmann, T.W.: Arch. ges. Physiol., 3, $247,1870$.

35) Edwards, D.: J. Urol., 65, 93, 1951.

36) Edwards, D.: Brit. med. J. Urol., 29, 410, 1958.

37) Fuchs, F.: Z. Urol. Chir., 21, 201, 1927.

38) Fuchs, F.: Z. Urol. Chir., 33, 1, 1931.

39) Fuchs, F.: Z. Urol. Chir., 37, 154, 1933.

40) Fuchs, F.: Z. Urol. Chir., 42, 80, 1936.

41）藤井覚: 皮紀要, $22,38: 43$, 昭8.

42) Goldstein, A.E.: J. Urol., 6, 125, 1921.

43) Haebler,H.: Z. Urol., 16, 145, 377, 1922.

44) Haebler, H.: Z. Urol., 17, 397, 1923.

45) Haebler, H.: Z. Urol. Chir., 16, 227, 1924.

46) Haebler, H.: Z. Urol., 19, 332, 1925.

47) Hanley, H.G.: Brit. J. Urol., 25, 358, 1953.

48) Hanley, H.G.: Brit. J. Urol., 2, 22, 1955. 
49）狭間文一：日本苩物学雑誌， $12 ， 43$ ，昭6.

50) Heckenbach, W.: Z. Urol., Chir., 35, 34, 1932.

51) Heckenbach, W.: Z. Urol., 27, 207, 1933.

52） Henle, J.: 辻上り引用, 㛑の平滑笳.

53) Hennig, O.: Schweiz. med. W., II, 629, 1937.

54) Herbst, R.\& Merio, P.: Fortschr. Röntgenstr., 56, 418, 1937.

55) Herbst, W.: J. Urol., 26, 233, 1931.

56) Hryntschak, T.: Z. Urol., 24, 549, 1930.

57) Hryntschak, T.: Z. Urol., 25, 875, 1931.

58）生亀芳雄：日泌尿会誌，48，352，昭32.

59 ）生龟芳雄：日泌尿会誌， $48 ， 605 ； 616$, 昭32.

60 ）市川篤二等：日泌尿会誌，24，376：509, 昭10.

$61 ）$ 市川篤二等：日泌尿会誌， 25,441 , 昭 11 .

$62 ）$ 市川篤二等 : 日泌尿会誌， $27,264: 266$, 昭13.

63）市川篤二等：皮尿誌，48，143，昭15.

64) Johnson, T.H.: New York State J. Med., 52, 189, 1952.

65) Jona, J.L. \& Flecker, H.: Surg. Gynec. \& Obst., 51, 50, 1930.

66) Junker, H.: Z. Urol., 30, 231, 1936.

67）兼松鋭男：日泌尿会誌，37，23，昭21.

68）兼松鋭男：生体「レ」線活動写真に上る腎結核 患者の上部尿路運動に就いて, 昭 21 .

69）河石九二夫, 山口圭造 : 愛知医学雑誌, 36, 1330, 昭 4 .

70）河石九二夫等 : グレンッダビート，10，1411, 昭11.

71) Kawaishi, K.: Am. J. Roentgenol., 40, 913, 1938.

72) Kiil, F.: The function of the ureter and renal pelvis, W.B. Saunders Co. Philadelphia \& London, 1957.

73）木下和雄：皮紀要， $20 ， 465$, 昭7.

74）木下和雄：皮紀要, 21,1 ： $157 ； 235 ； 429$, 昭8.

75）木下和雄：皮紀要， $22 ， 29$, 昭8.

76）上下正文：皮尿誌，43，718，昭13.

77) Lacus, D.R.: Am. J. Physiol., 22, 245, 1908.

78) Lapides, J.: J. Urol., 59, 501, 1948.

79) Lapides, J. \& Dodson, A.: J. Urol., 69, 96, 1953.

80) Lauber, H.J. \& Scherer, F.: Fortschr. Röntgenstr., 61, 222, 1940.

81) Lowsley, O.S \& Kirwin, T.J.: Clinical Urology, Williams \& Wilkins Co. Bakimore 1956.

82) Lusted, L.B. \& Miller, E.R.: J. Roentgenol \& Rad. Therap., 75, 56, 1956.

83) Maintz, M. \& Meese, J.: Z. Urol., 32, 756, 1938.
84) Maintz, M. et al.: Z. Urol., 32, 682, 1938.

85) Manges, W.F.: Am. J. Roentgenol., 5, 165, 1918.

86) Milton, G.W. \& Robb, W.A.T.: Brit. J. Urol., 26, 274, 1954.

87）水野治徳：論文「レ線活動写真による前立腺肥 大症患者の排尿運動について」，昭21。

88）三矢辰雄：日泌尿会誌， 25,441 , 昭 11.

89）三矢辰雄，田村栄樹：日泌尿会誌，26，536, 昭 12.

90 ）三矢展雄，田村栄樹：日泌尿会誌，27，266, 昭 13.

91 三矢辰雄: 泌尿器科学, 金原出版, 昭 27 .

92）三矢辰雄他：皮唐と泌尿，19，117，昭32。

93）三矢英戟他：J. Urol., 83， 86， 1960.

94) Morales, P.A. et al.: J. Urol., 67, 484, 1952.

95）村上武夫：名古屋医会誌，55，37，昭16.

96) Muschat, M.: J. Urol., 16, 351, 1926.

97) Muschat, M.: Am. J. Med. Sci., 176, 851, 1928.

98) Muschat, M.: J. Pharmacol., 37, 297, 1929.

99) Narath, P.A.: J. Urol., 43, 145, 1940.

100) Narath, P.A.: Urology. Campbell, Philadelphia W.B. Saunders Co., 1954.

101）成田元彦：日泌尿会誌，43，128, 昭27.

102）根岸博, 小島理一：日泌尿会誌, 20,203 , 昭 6 .

103) Oekonomos, S.: Z. Urol., 31, 610, 1937.

104）尾形一郎：皮尿誌, 28, 688, 昭3.

105）小野沝：日泌尿会誌, 30,213 , 昭 16.

106）太田嘉彦：論文「生体レ線活動写真に上る輸 尿管結石患者の上部尿路運動の研究」, 昭 20.

107）大原誠：論文「生体レ線活動写真による人体 上部尿路の排尿運動像の研究」, 昭20.

108) Orbeli, L. \& Brücke, E.T.: Arch. ges. Physiol., 133, 341, 1910.

109) Pflaumer, E. \& Hocker, H.: Z. Chir., 229, 309, 1930.

110) Reynold, R.: cit. Lusted, J. Roent. \& Rad. Therap., 75, 56, 1956.

111) Reynold, R.J.: Am. J. Roentgenol., 33, 522, 1935.

112）佐谷有吉 : Am. J. Physiol., 49, 474, 1916.

113）佐谷有吉：J. Urol., 3, 213, 1919.

114）佐谷有吉：日泌尿会誌, 11,278 , 大 12.

$115 ）$ 佐藤忠敏：名古屋医学誌, 78, 541, 昭 34.

116）清水圭三：治療，33，564，昭26.

117）清水圭三：手術，5,284，昭26.

$118 ）$ 清水圭三：日医事新報，1452，17，昭 27 .

119）清水圭三：日医事新報，1546，9，昭28.

120）清水圭三：手術，9，34，昭30.

$121 ）$ 清水圭三, 吉川康史：日本臨床, 10,338 , 昭 27 .

122）清水圭三, 吉川康史：臨床皮泌，7,519, 昭28.

123）清水圭三, 吉川康史：Nagoya J. med. Science, 
17, 286, 1954

124）清水圭三, 吉川康史：臨床皮泌, 10, 439, 昭31.

125) Stewart, W.H. et al.: Am. J. Roentgenol., $38,465,1937$.

126）杉稜一：日外会誌, 36,2218 , 昭 10 .

127）杉稜一：日外会誌， $42 ， 625$, 昭 16 .

128）高橋明, 土屋文雄：皮尿誌，39，769, 昭11.

129）高橋明等：グレンツゲビート， 12，71, 昭13.

130) 高橋明等: 日新医学, 30, 1531, 昭 16.

131) Trattner, H.R.: Z. Urol. Chir., 34, 365, 1932.

132) Trattner, H.R.: J. Urol., 28, 1, 1932.

133）土屋交雄：皮尿誌，37，639，昭12.

134) 辻一郎 : 腎の平滑筋, 南江堂, 昭 28 .
135) Wassink, W.F., Zit. Haebler: Z. Urol., 16, $377,1922$.

136) Westenhöfer, M.: Z. Urol., 17. 5, 1923.

137) Westenhöfer, M.: Z. Urol. Chir., 16, 228, 1924.

138) Wharton, L.R.: J. Urol., 28, 639, 1932.

139) Wu, P.P.T.: J. Urol., 30, 3G7, 1937.

140) Wüllenweber, G.: Z. Urol., 31, 339, 1937.

141）山口圭造: 日外会誌, 34,883 , 昭8.

142 ) 矢野正武 : 東北医学雑誌，30，419,昭17.

$143)$ 横竹次郎: 名古屋医学雑誌, 75, 1123, 昭32.

144）吉川康史：名古屋医学雑誌，70, 838, 昭30.

145) Zanne, D.D.: Z. Urol., 30, 841, 1936.

146) Zanne D.D.: Z. Urol., 31, $171: 464,1937$. 